\title{
Mechanochemistry of Metal Hydrides: Recent Advances ${ }^{\dagger}$
}

\author{
Jacques Huot ${ }^{1, *(\mathbb{D}}$, Fermín Cuevas ${ }^{2}{ }^{(\mathbb{D}}$, Stefano Deledda ${ }^{3} \mathbb{D}$, Kaveh Edalati $^{4}$, Yaroslav Filinchuk ${ }^{5}$, \\ Thierry Grosdidier ${ }^{6}$, Bjørn C. Hauback ${ }^{3}$, Michael Heere ${ }^{7}\left(\mathbb{D}\right.$, Torben R. Jensen ${ }^{8}(\mathbb{D}$, \\ Michel Latroche ${ }^{2}$ and Sabrina Sartori ${ }^{9, * \mathbb{D}}$ \\ 1 Hydrogen Research Institute, Département de Chimie, Biochimie et Physique, Université du Québec à \\ Trois-Rivières, Trois-Rivières, QC G9A 5H7, Canada \\ 2 Institut de Chimie et des Matériaux Paris Est (UMR7182), CNRS, UPEC, F-94320 Thiais, France \\ 3 Department for Neutron Materials Characterization, Institute for Energy Technology, P.O. Box 40, \\ NO-2027 Kjeller, Norway \\ 4 WPI, International Institute for Carbon-Neutral Energy Research (WPI-I2CNER), Kyushu University, \\ Fukuoka 819-0395, Japan \\ 5 Institute of Condensed Matter and Nanosciences, Université catholique de Louvain, Place L. Pasteur 1, \\ 1348 Louvain-la-Neuve, Belgium \\ 6 Laboratoire d'Étude des Microstructures et de Mécanique des Matériaux (LEM3), Université de Lorraine, \\ CNRS UMR 7239, 7 rue Félix Savart, BP 15082, CEDEX 03, 57073 Metz, France \\ 7 Institute for Applied Materials-Energy Storage Systems (IAM-ESS), Karlsruhe Institute of Technology \\ Hermann-von-Helmholtz-Platz 1, 76344 Eggenstein-Leopoldshafen, Germany \\ 8 Interdisciplinary Nanoscience Center (iNANO) and Department of Chemistry, University of Århus, \\ Langelandsgade 140, DK-8000 Århus C, Denmark \\ 9 Department of Technology Systems, University of Oslo, NO-2027 Kjeller, Norway \\ * Correspondence: Jacques.huot@uqtr.ca (J.H.); sabrina.sartori@its.uio.no (S.S.) \\ + Dedicated to Dr. Etsuo Akiba for his lifetime achievement in the field of metal hydrides and \\ mechanochemistry.
}

Received: 24 June 2019; Accepted: 24 August 2019; Published: 29 August 2019

Abstract: This paper is a collection of selected contributions of the 1st International Workshop on Mechanochemistry of Metal Hydrides that was held in Oslo in May 2018. In this paper, the recent developments in the use of mechanochemistry to synthesize and modify metal hydrides are reviewed. A special emphasis is made on new techniques beside the traditional way of ball milling. High energy milling, ball milling under hydrogen reactive gas, cryomilling and severe plastic deformation techniques such as High-Pressure Torsion (HPT), Surface Mechanical Attrition Treatment (SMAT) and cold rolling are discussed. The new characterization method of in-situ X-ray diffraction during milling is described.

Keywords: Mechano-synthesis; cryomilling; high-pressure torsion; cold rolling; metal hydrides; reactive ball milling; surface mechanical attrition; in-situ characterization.

\section{Introduction}

Since the pioneering work of Benjamin, mechanochemical treatment has been extensively used to produce new materials or to enhance properties of existing alloys [1,2]. In the field of metal hydrides, the most extensively used method has been ball milling. Very interesting and important results were achieved by using ball milling to synthesize and modify metal hydrides. However, other techniques should be considered as they could bring other types of effect on the metal hydrides and also may be more appropriate for industrial applications. 
From an historical point of view, metal or complex hydrides for energy storage applications were synthesized by solvent-based or by direct solid-gas hydrogenation reactions. Although these techniques are important, during the past two decades, advanced mechanochemistry has become increasingly dominating. Traditionally, "ball milling" was used as a grinding technique, e.g., to provide homogenous well mixed powder samples with reduced particle size for solid-state reactions as well as for mechanical alloying of metals [3]. Mechanochemistry was considered limited to alloying reactions, by "random mixing of atoms".

Today, more advanced techniques are developed, which combine preparation of reactive precursors for solvent-based synthesis and mechanochemistry [4]. Nevertheless, the technique has advanced significantly since the usage in "grinding mode". Today, the ball milling mode is associated with mechanochemistry. It is one of the most widely accepted and easily employable techniques for materials scientists, as no Schlenk line manipulations are required [5].

Solid-state chemists widely use "ball milling" for the synthesis and preparation of novel metal hydrides as new materials for energy storage and battery technologies and, with that, for new solutions within "sustainable green chemistry", i.e., solvent free synthesis methods [3,6-8].

Mechanochemical synthesis can be conducted under a range of different conditions, such as cryogenic temperatures, under inert or reactive atmosphere, or at elevated gas pressures or in a solvent, and/or with high-impact energy between the reacting compounds [9-11]. Hence, mechanochemistry is a very versatile technique, which can be employed for preparation of a wide range of novel materials [5].

Hydrogen has an extremely diverse chemistry and forms compounds with most elements in the periodic table. Mechanochemistry has been widely used to prepare new types of hydrides and has significantly expanded the variety of compositions and structures of these materials. Initially, the interest was focused on solid state hydrogen storage [12-15], mainly based on magnesium hydride [16-18]. Mechanochemistry has provided a variety of new composite samples and knowledge of additives effect and alloying reactions. In the past two decades, a wide range of complex metal hydrides have been synthesized using mechanochemistry [19]. These compounds are very interesting new classes of energy materials for batteries and hydrogen storage applications [20-22].

This review presents the latest achievements in the field using high-energy ball milling, cryomilling, milling under hydrogen pressure, and milling while investigation via in situ diffraction. In addition, other mechanochemical methods are discussed. This is justified from a fundamental as well as a practical point of view. Fundamentally, other techniques could bring different characteristics to the processed alloys, for example texture, low or high angle grain boundaries, different types of defects, etc. From a practical point of view, other techniques beside ball milling should be investigated for large scale applications. Recently, Severe Plastic Deformation (SPD) techniques such as High-Pressure Torsion (HPT) and Cold Rolling (CR) have been investigated for processing metal hydrides. In the following, the effect on metal hydrides synthesis and performances of various mechanochemical techniques are presented and discussed.

\section{High-Energy Mechanochemical Synthesis}

Deeper knowledge to the chemistry in the "black box", i.e., the closed ball milling vial, has facilitated advanced utilization of high-energy mechanochemistry as an adequate tool for material synthesis. The products obtained with this approach may often be impossible to prepare by standard solvent-based methods. Moreover, "over-milling" of less stable materials often leads to "destructive chemical reactions" and to the synthesis of decomposition products. This section introduces the experimental approach of high-energy ball milling along with selected examples, challenges and pitfalls, which need to be considered. We add a detailed discussion of which reactions may take place in the vial during mechanochemical treatment. 


\subsection{The Planetary Ball Mill}

The planetary ball mill is the focus in this section due to its versatility described below. Nevertheless, there are types of ball mills with even higher impact energies such as the SPEX shaker mills. Advanced planetary ball mills, such as the Fritsch Pulverisette (FRITSCH GmbH) No. 4, 5 or 6 are widely used. And the Pulverisette No. 4 consists of a main disk and two secondary disks, called planets, which have named the apparatus. Vials containing the reaction mixture and a defined number of balls are mounted on the top of the planets. The balls and vial are ideally made or coated with the same material, e.g., steel, tungsten carbide (WC), aluminum oxide $\left(\mathrm{Al}_{2} \mathrm{O}_{3}\right)$ or zirconium oxide $\left(\mathrm{ZrO}_{2}\right)$. These materials have different density, hardness and other mechanical properties, which explains why it is best to use the same material during milling to avoid gradients in hardness and, therefore, avoid destructive forces on one of the materials.

The vials can be loaded in an inert atmosphere inside a glove box. Typical ball-to-powder mass ratio is between $\sim 10: 1$ and $\sim 35: 1$. The lower is the ratio, the lower is the ball-to-ball and ball-to-vial friction. Thus, a higher ratio favors a higher contamination of the sample with impurities from balls and vial material, combined with the hardness and mechanical properties of balls and vial. Modifications in experimental parameters may compromise the purity of the obtained products.

The main disk and the planets are rotating in opposite directions, and the planets rotate reversely usually at twice the speed of the main disk. Typical speeds are between 200 and $400 \mathrm{rpm}$, causing the balls to move and fly inside the vials. The Fritsch Pulverisette No. 4 allows the speed of the planets, $\omega$, to be varied independently of the main disk speed, $\Omega$ [23]. In fact, the relative rotation speed, $\omega / \Omega$, during mechanochemical treatment determines the trajectory of the balls inside the vial [24]. The ball trajectories also depend on the mill geometry, i.e., the ratio between the main disk radius, $R$, and the vial radius, $r$. The ball trajectories can be used to subdivide the approach in two regimes: (a) the traditional grinding mode where the balls follow the circumference of the vial; and (b) the high-energy mode with ball trajectories approaching the center of the vial. The main focus here is on the latter high-energy regime.

The ball trajectories through the center of the vial produce large impact energies mainly between balls and vial wall. This energy can be further optimized using a vial with limited height and larger diameter. However, ball material density, ball diameter (i.e., mass of balls), ball-to-powder ratio also determine the impact energy. The impact energy can be calculated according to Refs. $[25,26]$ and are further discussed in Ref. [3]. The high energies produced by collisions of the balls and vial walls indicates that few larger balls facilitate high-impact energies rather than many smaller balls.

The variation of the main disk speed, $\Omega$, is necessary to obtain different milling energies, i.e., higher rotational speeds provide larger impact energies of the balls on the powder material in the vial. Furthermore, the larger main disk speed provides a larger number of impacts per unit time and, thereby, increases the total amount of energy transferred to the powder [3]. However, the higher energy transferred to the material along with the unavoidable frictional energy will heat up the material and temperatures higher than $100^{\circ} \mathrm{C}$ may readily be achieved. This, often unwanted, heating effect may be limited by intervening the mechanochemical treatment by pauses, e.g., $2-5$ min milling followed by 2-5 min pause, etc.

\subsection{Solvent Free Synthesis of Metal Borohydrides}

Metal borohydrides are well known as a reducing agent in organic chemistry [27]. The first mechanochemical synthesis of metal borohydride was shown in 1953 for the synthesis of sodium borohydride from boric oxide and sodium hydride (see Reaction (1)) [28,29].

$$
4 \mathrm{NaH}+2 \mathrm{~B}_{2} \mathrm{O}_{3} \rightarrow \mathrm{NaBH}_{4}+3 \mathrm{NaBO}_{2}
$$

A comprehensive overview of the borohydrides and their derivatives can be found in Refs. [30,31]. 
Initially, the preferred procedure for synthesizing $R E$ borohydrides was the "solvent-free" approach, where a $R E$-chloride and an alkali metal borohydride ( $\mathrm{Li}, \mathrm{Na}$, and $\mathrm{K}$ ) are reacted in a one-step mechanochemical synthesis [31,32]. Thus far, $\mathrm{LiBH}_{4}$ has proven to be the most efficient precursor during these reactions, possibly due to formation of the stable reaction product $\mathrm{LiCl}$ [31-48]. However, other alkali metal borohydrides, i.e., $\mathrm{NaBH}_{4}$ and $\mathrm{KBH}_{4}$, have been employed as well as rare earth metal hydrides [49].

Metathesis reaction. The above-mentioned examples mainly utilize the metathesis, or double substitution reaction. A classic example is the synthesis of $Y\left(\mathrm{BH}_{4}\right)_{3}$ from the reactants $\mathrm{YCl}_{3}-\mathrm{LiBH}_{4}(1: 3)$, which also results in the formation of the unwanted product $\mathrm{LiCl}$, according to Reaction (2) [36,37].

$$
\mathrm{YCl}_{3}+3 \mathrm{LiBH}_{4} \rightarrow \mathrm{Y}\left(\mathrm{BH}_{4}\right)_{3}+3 \mathrm{LiCl}
$$

The polymorph $\alpha-\mathrm{Y}\left(\mathrm{BH}_{4}\right)_{3}$ was previously obtained by a solvent-based method in diethyl ether using solutions of $\mathrm{LiBH}_{4}$ and $\mathrm{YCl}_{3}$ at room temperature (RT), but this polymorph was also obtained by ball milling with varying amounts of another new polymorph, $\beta-\mathrm{Y}\left(\mathrm{BH}_{4}\right)_{3}[36,37] . \alpha-\mathrm{Y}\left(\mathrm{BH}_{4}\right)_{3}$ is considered the stable polymorph at ambient conditions, whereas $\beta-\mathrm{Y}\left(\mathrm{BH}_{4}\right)_{3}$, is assumed to be a high-pressure polymorph, but the $\beta$-polymorph is also stable at RT [35-37,50]. The $\beta$-polymorph is suggested to form by a $\alpha$ - to $\beta-\mathrm{Y}\left(\mathrm{BH}_{4}\right)_{3}$ polymorphic transition due to the high pressure during mechanochemical treatment.

Addition reaction. Another established but less often observed reaction is the addition. This is illustrated by the synthesis of $\mathrm{KZn}\left(\mathrm{BH}_{4}\right) \mathrm{Cl}_{2}$ obtained by mechanochemical treatment of a mixture of $\mathrm{ZnCl}_{2}$ and $\mathrm{KBH}_{4}(1: 1)[5,51]$, as shown in Reaction (3).

$$
\mathrm{ZnCl}_{2}+\mathrm{KBH}_{4} \rightarrow \mathrm{KZn}\left(\mathrm{BH}_{4}\right) \mathrm{Cl}_{2}
$$

It is highly interesting to note that the new compound $\mathrm{KZn}\left(\mathrm{BH}_{4}\right) \mathrm{Cl}_{2}$ contains the heteroleptic complex ion $\left[\mathrm{Zn}\left(\mathrm{BH}_{4}\right) \mathrm{Cl}_{2}\right]^{-}$where $\mathrm{Zn}$ coordinates to two chloride ions and two hydrogen atoms in $\eta^{2}-\mathrm{BH}_{4}, \mathrm{CN}(\mathrm{Zn})=4[51]$.

The addition reaction, Reaction (3), clearly create a material with a fully ordered crystal structure, hence, contrasts the synthesis of the solid solution shown in Reaction (4).

$$
(1-\mathrm{x}) \mathrm{LiBH}_{4}+\mathrm{xLiCl} \rightarrow \mathrm{Li}\left(\mathrm{BH}_{4}\right)_{1}-{ }_{\mathrm{x}} \mathrm{Cl}_{\mathrm{x}}
$$

Complex mechanochemical reactions. Mechanochemistry has provided a series of new lithium ion conductors, $\mathrm{LiRE}\left(\mathrm{BH}_{4}\right)_{3} \mathrm{Cl}, \mathrm{RE}=\mathrm{Ce}, \mathrm{La}, \mathrm{Gd}$, which likely cannot be prepared by any other method [52]. Initially, a new compound, $\mathrm{LiCe}\left(\mathrm{BH}_{4}\right)_{3} \mathrm{Cl}$, was discovered in a mechanochemically treated sample of $\mathrm{CeCl}_{3}-\mathrm{LiBH}_{4}$ (1:3). The complex reaction is believed to be a coupled metathesis and addition reaction, described by Reactions (5) and (6), below.

$$
\begin{gathered}
\mathrm{CeCl}_{3}+3 \mathrm{LiBH}_{4} \rightarrow \mathrm{Ce}\left(\mathrm{BH}_{4}\right)_{3}+3 \mathrm{LiCl} \\
\mathrm{Ce}\left(\mathrm{BH}_{4}\right)_{3}+\mathrm{LiCl} \rightarrow \mathrm{LiCe}\left(\mathrm{BH}_{4}\right)_{3} \mathrm{Cl}
\end{gathered}
$$

The system $\mathrm{LaCl}_{3}-\mathrm{LiBH}_{4}$ can be used to illustrate the complexity of the mechanochemical synthesis as ball milling of this mixture (1:6) results in an addition reaction and a product of $\mathrm{LiLa}\left(\mathrm{BH}_{4}\right)_{3} \mathrm{Cl}[44,53]$.

Mechanochemical synthesis experiments in the $\mathrm{ZnCl}_{2}-\mathrm{MBH}_{4}$ system clearly proceeds via more complex chemical reactions [54].

$$
\begin{aligned}
2 \mathrm{ZnCl}_{2}+5 \mathrm{LiBH}_{4} & \rightarrow \mathrm{LiZn}_{2}\left(\mathrm{BH}_{4}\right)_{5}+4 \mathrm{LiCl} \\
2 \mathrm{ZnCl}_{2}+5 \mathrm{NaBH}_{4} & \rightarrow \mathrm{NaZn}_{2}\left(\mathrm{BH}_{4}\right)_{5}+4 \mathrm{NaCl} \\
\mathrm{ZnCl}_{2}+3 \mathrm{NaBH}_{4} & \rightarrow \mathrm{NaZn}\left(\mathrm{BH}_{4}\right)_{3}+2 \mathrm{NaCl}
\end{aligned}
$$


Reactions (7)-(9) are assumed to be complex combinations of metathesis and addition reactions. Surprisingly, Reactions (8) and (9) provide different products despite being conducted at the same mechanochemical conditions, but only with small differences in composition of reactants. These observations tend to suggest that a state of chemical equilibrium occurs during mechanochemical synthesis. Mechanochemistry of reactants with dominantly ionic and covalent bonding clearly can lead to distinct chemical reactions and are not a statistical distribution of reactants as expected, e.g., for mechanical alloying of metals.

The structural topology of $\mathrm{NaZn}\left(\mathrm{BH}_{4}\right)_{3}$ and $\mathrm{MZn}_{2}\left(\mathrm{BH}_{4}\right)_{5}, \mathrm{M}=\mathrm{Li}$ or $\mathrm{Na}$, are significantly different, possibly owing to differences in the mechanisms in Reactions (7)-(9). Interestingly, the structures of $\mathrm{MZn}_{2}\left(\mathrm{BH}_{4}\right)_{5}, \mathrm{M}=\mathrm{Li}$ or $\mathrm{Na}$, are isostructural and built from two identical interpenetrated 3D frameworks consisting of isolated complex anions, $\left[\mathrm{Zn}_{2}\left(\mathrm{BH}_{4}\right)_{5}\right]^{-}$. This type of structural motif is known from open-structured molecular frameworks, so-called metallic organic frameworks (MOF). The compound $\mathrm{NaZn}\left(\mathrm{BH}_{4}\right)_{3}$ consists of a single three-dimensional network, containing $\left[\mathrm{Zn}\left(\mathrm{BH}_{4}\right)_{3}\right]^{-}$ (see Figure 1) [54,55] and, thus, reveals the complexity of mechanochemistry.

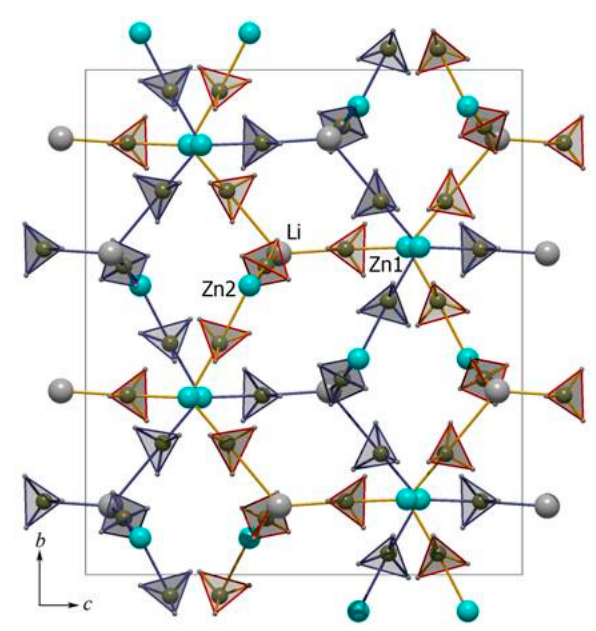

(a)

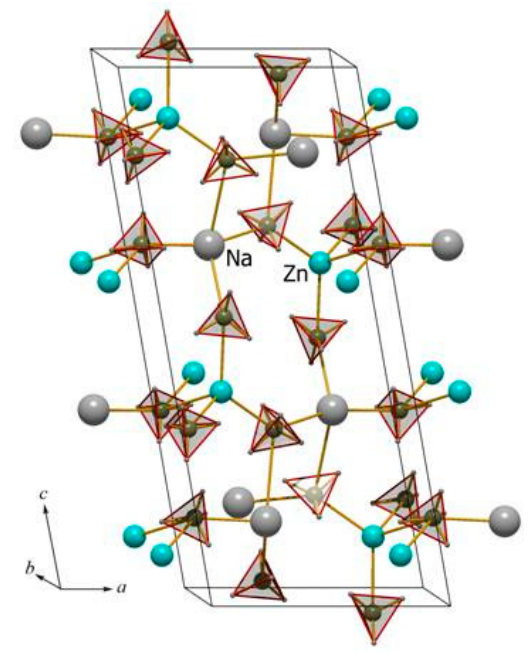

(b)

Figure 1. Crystal structure of $\mathrm{MZn}_{2}\left(\mathrm{BH}_{4}\right)_{5}, \mathrm{M}=\mathrm{Li}$ or $\mathrm{Na}$ : (a) built from isolated complex anions, $\left[\mathrm{Zn}_{2}\left(\mathrm{BH}_{4}\right)_{5}\right]$ and $\mathrm{NaZn}\left(\mathrm{BH}_{4}\right)_{3}$; and (b) consisting of a single three-dimensional network, containing $\left[\mathrm{Zn}\left(\mathrm{BH}_{4}\right)_{3}\right]^{-}$anions $[54,55]$.

Coupled chemical reactions. Reactions (7)-(9) illustrate the general drawback of metathesis related reactions. It shows that ionic compounds may contaminate the products-most often binary alkali metal halides but in some cases also ternary halides. Formation of $\mathrm{LiZn}_{2}\left(\mathrm{BH}_{4}\right)_{5}$ in Reaction (7) proceeds completely, i.e., with formation of $\mathrm{LiCl}$ as the only side product, in contrast to $\mathrm{NaZn}_{2}\left(\mathrm{BH}_{4}\right)_{5}$ and $\mathrm{NaZn}\left(\mathrm{BH}_{4}\right)_{3}$, Reactions (8) and (9), which only proceeds partly due to presence of a simultaneous and competing reaction forming a ternary metal chloride (see Reaction (10)).

$$
\mathrm{ZnX}_{2}+2 \mathrm{MX} \rightarrow \mathrm{M}_{2} \mathrm{ZnX}_{4}
$$

This type of side reactions seems to be more pronounced the heavier the halide and alkali metal elements are, e.g., the ease of formation order of: $\mathrm{Na}_{2} \mathrm{ZnBr}_{4}>\mathrm{Na}_{2} \mathrm{ZnCl}_{4}>\mathrm{Li}_{2} \mathrm{ZnCl}_{4}$ [56]. These three compounds are prepared mechanochemically using stoichiometric mixtures of $M X$ and $Z n X_{2}$. However, formation of minor amounts of $\mathrm{M}_{2} \mathrm{ZnX} \mathrm{X}_{4}$ suggests that Reaction (10) is only weakly coupled with the formation of the metal borohydrides, i.e., Reactions (8) and (9) are faster than Reaction (10).

Side reaction may also be strongly coupled to the reaction forming the product, which has strong consequences for composition of the product and the optimal reactant composition. An 
illustrative example is the synthesis of alkali metal scandium borohydrides, $\mathrm{NaSc}\left(\mathrm{BH}_{4}\right)_{4}$ and $\mathrm{KSc}\left(\mathrm{BH}_{4}\right)_{4}$, by mechanochemistry from the reactants $\mathrm{ScCl}_{3}$ and $\mathrm{NaBH}_{4}$ or $\mathrm{KBH}_{4}$ (Reactions (11) and (12)) $[57,58]$.

$$
\begin{gathered}
\mathrm{ScCl}_{3}+4 \mathrm{NaBH}_{4} \rightarrow \mathrm{NaSc}\left(\mathrm{BH}_{4}\right)_{4}+3 \mathrm{NaCl} \\
\mathrm{ScCl}_{3}+4 \mathrm{KBH}_{4} \rightarrow \mathrm{KSc}\left(\mathrm{BH}_{4}\right)_{4}+3 \mathrm{KCl}
\end{gathered}
$$

However, alkali metal halides were not detected by powder $\mathrm{X}$-ray diffraction in the product of any of the ball-milled samples of $\mathrm{ScCl}_{3}-\mathrm{MBH}_{4}(\mathrm{M}=\mathrm{Na}$ or $\mathrm{K})$ in molar ratios 1:2, 1:3 or 1:4. This suggests that other, faster, reactions take place simultaneously, which consume the formed alkali metal halide, and indeed a new ternary alkali scandium chloride $\mathrm{M}_{3} \mathrm{ScCl}_{6}$ was identified. Surprisingly, the $\mathrm{ScCl}_{3}-\mathrm{MBH}_{4}$ (1:2) samples show diffraction from neither $\mathrm{ScCl}_{3}$ nor $\mathrm{MBH}_{4}$ and appear to contain the largest fraction of products $\mathrm{NaSc}\left(\mathrm{BH}_{4}\right)_{4}$ and $\mathrm{KSc}\left(\mathrm{BH}_{4}\right)_{4}[57,58]$. Furthermore, the sample ratios $\mathrm{ScCl}_{3}-\mathrm{MBH}_{4}$ (1:3) and (1:4) contain different amounts of $\mathrm{MBH}_{4}$ but no diffraction from $\mathrm{ScCl}_{3}$. These observations are assigned to an addition reaction, which is responsible for the formation of $\mathrm{Na}_{3} \mathrm{ScCl}_{6}$ and $\mathrm{K}_{3} \mathrm{ScCl}_{6}$ (see Reactions (13) and (14)).

$$
\begin{gathered}
\mathrm{ScCl}_{3}+3 \mathrm{NaCl} \rightarrow \mathrm{Na}_{3} \mathrm{ScCl}_{6} \\
\mathrm{ScCl}_{3}+3 \mathrm{KCl} \rightarrow \mathrm{K}_{3} \mathrm{ScCl}_{6}
\end{gathered}
$$

Assuming that the reactions for the formation of the ternary salts, $\mathrm{M}_{3} \mathrm{ScCl}_{6}$, Reactions (13) and (14) are much faster as compared to the formation of the metal borohydrides, $\mathrm{MSc}\left(\mathrm{BH}_{4}\right)_{4}$ (see Reactions (11) and (12)). Therefore, the Reactions (13) and (14) are strongly coupled to Reactions (11) and (12), respectively. Such reactions can be added together to form a reaction scheme for the overall reactions (see Reactions (15) and (16)). These reactions reveal that the optimal ratio for formation of $\mathrm{MSc}\left(\mathrm{BH}_{4}\right)_{4}$ and $\mathrm{M}_{3} \mathrm{ScCl}_{6}$ is in fact $\mathrm{ScCl}_{3}-\mathrm{MBH}_{4}(1: 2)$ and the maximum yields of $\mathrm{NaSc}\left(\mathrm{BH}_{4}\right)_{4}$ and $\mathrm{KSc}\left(\mathrm{BH}_{4}\right)_{4}$ were 22 and $18 \mathrm{wt} \%$, respectively.

$$
\begin{aligned}
2 \mathrm{ScCl}_{3}+4 \mathrm{NaBH}_{4} & \rightarrow \mathrm{NaSc}\left(\mathrm{BH}_{4}\right)_{4}+\mathrm{Na}_{3} \mathrm{ScCl}_{6} \\
2 \mathrm{ScCl}_{3}+4 \mathrm{KBH}_{4} & \rightarrow \mathrm{KSc}\left(\mathrm{BH}_{4}\right)_{4}+\mathrm{K}_{3} \mathrm{ScCl}_{6}
\end{aligned}
$$

The lithium system $\mathrm{ScCl}_{3}-\mathrm{LiBH}_{4}$ did not show any formation of ternary metal halides and one reaction scheme explains the formation of $\mathrm{LiSc}\left(\mathrm{BH}_{4}\right)_{4}$ and $\mathrm{LiCl}[57,58]$. Table 1 summarizes selected mechanochemical reactions.

Table 1. Metal borohydrides synthesized by mechanochemical methods, reactants used for the synthesis, optimal reactant ratio, formed side products, total milling time (tmt in minutes) and milling speed (revolutions per minute, rpm) used in the synthesis [5].

\begin{tabular}{ccccccc}
\hline Compound & Reactants Opt. & Ratio & Side Products & tmt & rpm & Ref. \\
\hline $\mathrm{NaBH}_{4}$ & $\mathrm{MgH}_{2}+\mathrm{Na}_{2} \mathrm{~B}_{4} \mathrm{O}_{7}$ & $4: 1$ & $\mathrm{MgO}, \mathrm{B}_{2} \mathrm{O}_{3}$ & 60 & 2750 & {$[28,59]$} \\
$\mathrm{KBH}_{4}$ & $\mathrm{MgH}_{2}+\mathrm{KBO}_{2}$ & $2: 1$ & $\mathrm{MgO}$ & 120 & 490 & {$[60]$} \\
$\mathrm{Sr}\left(\mathrm{BH}_{4}\right) \mathrm{Cl}$ & $\mathrm{LiBH}_{4}+\mathrm{SrCl}_{2}$ & $1: 1$ & $\mathrm{LiCl}, \mathrm{Sr}\left(\mathrm{BH}_{4}\right)_{2}$ & 120 & 400 & {$[61]$} \\
$\mathrm{Sr}\left(\mathrm{BH}_{4}\right)_{2}$ & $\mathrm{LiBH}_{4}+\mathrm{SrCl}_{2}$ & $1: 1$ & $\mathrm{LiCl}, \mathrm{Sr}\left(\mathrm{BH}_{4}\right) \mathrm{Cl}$ & 120 & 400 & {$[61]$} \\
$\mathrm{LiSc}\left(\mathrm{BH}_{4}\right)_{4}$ & $\mathrm{LiBH}_{4}+\mathrm{ScCl}_{3}$ & $4: 1$ & $\mathrm{LiCl}$ & 180 & 500 & {$[62-64]$} \\
$\mathrm{NaSc}\left(\mathrm{BH}_{4}\right)_{4}$ & $\mathrm{NaBH}_{4}+\mathrm{ScCl}_{3}$ & $2: 1$ & $\mathrm{Na}_{3} \mathrm{ScCl}_{6}$ & 120 & 400 & {$[57]$} \\
$\mathrm{KSc}\left(\mathrm{BH}_{4}\right)_{4}$ & $\mathrm{KBH}_{4}+\mathrm{ScCl}_{3}$ & $2: 1$ & $\mathrm{~K}_{3} \mathrm{ScCl}_{6}$ & 120 & 400 & {$[58]$} \\
$\mathrm{Y}\left(\mathrm{BH}_{4}\right)_{3}$ & $\mathrm{LiBH}_{4}+\mathrm{YCl}_{3}$ & $3: 1$ & $\mathrm{LiCl}$ & 120 & 200 & {$[36,37]$} \\
$\mathrm{NaY}\left(\mathrm{BH}_{4}\right)_{2} \mathrm{Cl}_{2}$ & $\mathrm{NaBH}_{4}+\mathrm{YCl}_{3}$ & $2: 1$ & $\mathrm{Na}_{3} \mathrm{YCl}_{6}, \mathrm{Na}\left(\mathrm{BH}_{4}\right)_{1-\mathrm{x}} \mathrm{Cl}_{\mathrm{x}}$ & 120 & 200 & {$[65]$} \\
$\mathrm{Mn}\left(\mathrm{BH}_{4}\right)_{2}$ & $\mathrm{LiBH}_{4}+\mathrm{MnCl}_{2}$ & $2: 1$ & $\mathrm{LiCl}$ & 350 & 600 & {$[66]$} \\
$\mathrm{Mn}\left(\mathrm{BH}_{4}\right)_{2}$ & $\mathrm{NaBH}_{4}+\mathrm{MnCl}_{2}$ & $2: 1$ & $\mathrm{NaCl}$ & 350 & 600 & {$[66]$} \\
$\mathrm{LiZn}_{2}\left(\mathrm{BH}_{4}\right)_{5}$ & $\mathrm{LiBH}_{4}+\mathrm{ZnCl}_{2}$ & $5: 2$ & $\mathrm{LiCl}$ & 120 & 200 & {$[54]$} \\
$\mathrm{NaZn}_{2}\left(\mathrm{BH}_{4}\right)_{5}$ & $\mathrm{NaBH}_{4}+\mathrm{ZnCl}_{2}$ & $5: 2$ & $\mathrm{Na}_{2} \mathrm{ZnCl}, \mathrm{NaCl}$ & 120 & 200 & {$[54]$} \\
\hline
\end{tabular}


Table 1. Cont.

\begin{tabular}{|c|c|c|c|c|c|c|}
\hline Compound & Reactants Opt. & Ratio & Side Products & tmt & rpm & Ref. \\
\hline $\mathrm{NaZn}\left(\mathrm{BH}_{4}\right)_{3}$ & $\mathrm{NaBH}_{4}+\mathrm{ZnCl}_{2}$ & $3: 1$ & $\mathrm{Na}_{2} \mathrm{ZnCl}_{4}, \mathrm{NaCl}$ & 120 & 200 & [54] \\
\hline $\mathrm{KZn}\left(\mathrm{BH}_{4}\right) \mathrm{Cl}_{2}$ & $\mathrm{KBH}_{4}+\mathrm{ZnCl}_{2}$ & 1:1 & $2-4$ & 120 & 200 & [51] \\
\hline $\mathrm{Cd}\left(\mathrm{BH}_{4}\right)_{2}$ & $\mathrm{LiBH}_{4}+\mathrm{CdCl}_{2}$ & 2:1 & $\mathrm{LiCl}$ & 30 & 200 & [67] \\
\hline $\mathrm{Cd}\left(\mathrm{BH}_{4}\right)_{2}$ & $\mathrm{NaBH}_{4}+\mathrm{CdCl}_{2}$ & $14: 9$ & $\mathrm{NaCl}, \mathrm{Na}_{6} \mathrm{CdCl}_{8}$ & 30 & 200 & {$[67]$} \\
\hline $\mathrm{KCd}\left(\mathrm{BH}_{4}\right)_{3}$ & $\mathrm{KBH}_{4}+\mathrm{CdCl}_{2}$ & 1:1 & $\mathrm{KCdCl}_{3}, \mathrm{~K}_{2} \mathrm{Cd}\left(\mathrm{BH}_{4}\right)_{4}, \mathrm{Cd}\left(\mathrm{BH}_{4}\right)_{2}$ & 20 & 200 & {$[67]$} \\
\hline $\mathrm{K}_{2} \mathrm{Cd}\left(\mathrm{BH}_{4}\right)_{4}$ & $\mathrm{KBH}_{4}+\mathrm{CdCl}_{2}$ & $4: 3$ & $\mathrm{KCdCl}_{3}$ & 20 & 200 & {$[67]$} \\
\hline $\mathrm{Li}_{4} \mathrm{Al}_{3}\left(\mathrm{BH}_{4}\right)_{13}$ & $\mathrm{LiBH}_{4}+\mathrm{AlCl}_{3}$ & $13: 3$ & $\mathrm{LiCl}$ & 300 & 500 & [68] \\
\hline $\mathrm{Li}\left(\mathrm{BH}_{4}\right)_{0.9} \mathrm{Cl}_{0.1}$ & $\mathrm{LiBH}_{4}+\mathrm{LiCl}$ & - & - & 120 & 200 & {$[69,70]$} \\
\hline $\mathrm{Li}\left(\mathrm{BH}_{4}\right)_{0.47} \mathrm{Br}_{0.53}$ & $\mathrm{LiBH}_{4}+\mathrm{LiBr}$ & - & - & 120 & 200 & [71] \\
\hline $\mathrm{Li}\left(\mathrm{BH}_{4}\right)_{0.3} \mathrm{I}_{0.7}$ & $\mathrm{LiBH}_{4}+\mathrm{LiI}$ & - & - & 120 & 200 & [72] \\
\hline $\mathrm{LiBH}_{4}-\mathrm{NaBH}_{4}$ & $\mathrm{LiBH}_{4}+\mathrm{NaBH}_{4}$ & $1: 1$ & $\mathrm{LiNaBH}_{4}$ & 300 & 175 & {$[73,74]$} \\
\hline $\mathrm{LiBH}_{4}-\mathrm{NaBH}_{4}-\mathrm{Ni}$ & $\mathrm{LiBH}_{4}+\mathrm{NaBH}_{4}+\mathrm{Ni}$ & - & $\mathrm{Ni}_{4} \mathrm{~B}_{3}, \mathrm{Ni}_{2} \mathrm{~B}, \mathrm{Ni}_{3} \mathrm{~B}$ & 300 & 175 & [74] \\
\hline $\mathrm{Na}\left(\mathrm{BH}_{4}\right)_{0.9} \mathrm{Cl}_{0.1}$ & $\mathrm{NaBH}_{4}+\mathrm{NaCl}$ & - & -1 & 120 & 200 & [75] \\
\hline $\mathrm{Ca}\left(\mathrm{BH}_{4}\right)_{1.6} \mathrm{I}_{0.4}$ & $\mathrm{Ca}\left(\mathrm{BH}_{4}\right)_{2}+\mathrm{CaI}_{2}$ & - & - & 120 & 250 & [76] \\
\hline $\mathrm{LiLa}\left(\mathrm{BH}_{4}\right)_{3} \mathrm{Cl}$ & $\mathrm{La}\left(\mathrm{BH}_{4}\right)_{3}+\mathrm{LiCl}$ & 1:1 & unknown phase & 120 & 350 & [77] \\
\hline $\mathrm{LiLa}\left(\mathrm{BH}_{4}\right)_{3} \mathrm{Br}$ & $\mathrm{La}\left(\mathrm{BH}_{4}\right)_{3}+\mathrm{LiBr}$ & $1: 1$ & unknown phase & 120 & 350 & [77] \\
\hline $\mathrm{LiLa}\left(\mathrm{BH}_{4}\right)_{3} \mathrm{I}$ & $\mathrm{La}\left(\mathrm{BH}_{4}\right)_{3}+\mathrm{LiI}$ & $1: 1$ & unknown phase & 120 & 350 & [77] \\
\hline $\mathrm{NaCe}\left(\mathrm{BH}_{4}\right)_{4}$ & $\mathrm{NaBH}_{4}+\mathrm{Ce}\left(\mathrm{BH}_{4}\right)_{3}$ & 1:1 & $\beta$-Ce $\left(\mathrm{BH}_{4}\right)_{3}$, unknown phase & 120 & 350 & [78] \\
\hline $\mathrm{NaPr}\left(\mathrm{BH}_{4}\right)_{4}$ & $\mathrm{NaBH}_{4}+\operatorname{Pr}\left(\mathrm{BH}_{4}\right)_{3}$ & 1:1 & unknown phase & 120 & 350 & [78] \\
\hline $\mathrm{NaEr}\left(\mathrm{BH}_{4}\right)_{4}$ & $\mathrm{NaBH}_{4}+\mathrm{Er}\left(\mathrm{BH}_{4}\right)_{3}$ & 1:1 & - & 120 & 350 & [78] \\
\hline $\mathrm{Na}\left(\mathrm{BH}_{4}\right)_{1-\mathrm{x}} \mathrm{Br}_{\mathrm{x}}$ & $\mathrm{NaBH}_{4}+\mathrm{NaBr}$ & $1: 1$ & - & 360 & 200 & [79] \\
\hline $\mathrm{KEr}\left(\mathrm{BH}_{4}\right)_{4}$ & $\mathrm{KBH}_{4}+\mathrm{Er}\left(\mathrm{BH}_{4}\right)_{3}$ & $1: 1$ & - & 60 & - & [80] \\
\hline
\end{tabular}

\subsection{Solvent Free Synthesis of "Reactive Hydride Composites"}

Reactive hydride composites (RHC) are a combination of materials following an approach to destabilize metal hydrides by the formation of multicomponent hydride mixtures and, thereby, lowering the stability or reaction enthalpy. This was first described by Reilly and Wiswall with the example of $\mathrm{MgH}_{2}+\mathrm{MgCu}_{2}$ formation upon absorption, and $\mathrm{Mg}_{2} \mathrm{Cu}+\mathrm{H}_{2}$ upon desorption [81]. The advantage of RHC is the possibility to conserve the high hydrogen content of the original materials while anion substitution may occur but decrease the hydrogen capacity only slightly.

In the early 2000s, Chen et al. described the RHC including $\mathrm{LiNH}_{2}$ and $\mathrm{LiH}$ (Reaction (17)).

$$
\mathrm{LiNH}_{2}+2 \mathrm{LiH} \rightarrow \mathrm{Li}_{2} \mathrm{NH}+\mathrm{LiH}+\mathrm{H}_{2} \rightarrow \mathrm{Li}_{3} \mathrm{~N}+2 \mathrm{H}_{2}
$$

In the following years, further RHC were investigated including $\mathrm{MgH}_{2}+\mathrm{NaBH}_{4}, \mathrm{MgH}_{2}+\mathrm{LiBH}_{4}$ and $\mathrm{MgH}_{2}+\mathrm{Ca}\left(\mathrm{BH}_{4}\right)_{2}$ [82-85]. It was discovered that $\mathrm{MgB}_{2}$, as a thermal reaction product, is crucial for rehydrogenation and offers a pathway for the formation of new borohydrides [82-84,86,87]. Eventually, a possibility to hydrogenate $2 \mathrm{LiH}$ and $\mathrm{MgB}_{2}$ including a catalyst $\left(2-3 \mathrm{~mol}^{2} \mathrm{TiCl}_{3}\right.$ ) following Reaction (18) was presented [82].

$$
2 \mathrm{LiBH}_{4}+\mathrm{MgH}_{2} \rightarrow 2 \mathrm{LiH}+\mathrm{MgB}_{2}+4 \mathrm{H}_{2}
$$

This RHC revealed a reduction in enthalpy from $67 \mathrm{~kJ} \mathrm{~mol}^{-1}$ of $\mathrm{H}_{2}$ for the $\mathrm{LiBH}_{4} / \mathrm{LiH}$ and B system to $42 \mathrm{~kJ} \mathrm{~mol}^{-1}$ of $\mathrm{H}_{2}$, therefore improving thermodynamic properties compared to pure $\mathrm{LiBH}_{4}$ immensely [82].

Further efforts have been made in investigating $\mathrm{NaH}+\mathrm{MgB}_{2}$, with a theoretical hydrogen capacity of $7.8 \mathrm{wt} \%$ for a 2:1 molar equivalent. The suggested reaction products upon hydrogenation are $2 \mathrm{NaBH}_{4}$ and $\mathrm{MgH}_{2}$, but an intermediate reaction product, $\mathrm{NaMgH}_{3}$, is formed, which decreases the hydrogen capacity substantially. Furthermore, the reaction is plagued with slow hydrogen sorption kinetics, meaning that $1 \mathrm{~h}$ is required to absorb $3.8 \mathrm{wt} \% \mathrm{H}$ at 50 bar hydrogen and $400{ }^{\circ} \mathrm{C}$, and this is the maximum experimentally obtained hydrogen absorption capacity [88-91]. To improve kinetics and absorption capacity, the approach of anion substitution and the influence of long-time milling has 
been investigated [92]. By substituting $10 \mathrm{~mol} \%$ of $\mathrm{NaH}$ by $\mathrm{NaF}$ and forming the $\mathrm{RHC}$ of $\mathrm{NaF}+9 \mathrm{NaH}$ $+\mathrm{MgB}_{2}$, reaction pathway in Reaction (19) is expected upon hydrogenation.

$$
\mathrm{NaF}+9 \mathrm{NaH}+5 \mathrm{MgB}_{2}+20 \mathrm{H}_{2} \rightarrow 10 \mathrm{NaBH}_{3.9} \mathrm{~F}_{0.1}+5 \mathrm{MgH}_{2}
$$

With a nominal hydrogen capacity of $7.7 \mathrm{wt} \%$, the hydrogen capacity is slightly decreased compared to the original RHC $(7.8 \mathrm{wt} \%)$. Additionally, the effect of ball milling was investigated with milling times of $87 \mathrm{~h}$ (long milled) and $5 \mathrm{~h}$ (short milled). These two samples absorb 6.0 and $6.3 \mathrm{wt} \% \mathrm{H}$, respectively. Therefore, the uptake of hydrogen is almost doubled compared to the original investigation under the reported conditions. However, a different hydrogenation pathway, with the products being $\mathrm{NaBH}_{4}, \mathrm{MgH}_{2}$ and $\mathrm{NaMgH}_{3-\mathrm{x}} \mathrm{F}_{\mathrm{x}}(0 \leq \mathrm{x} \leq 1)$, is observed. The thermodynamics are modified for the temperature of formation of $\mathrm{NaBH}_{4}$, which decreases from $380^{\circ} \mathrm{C}$ [91] to $206^{\circ} \mathrm{C}$ in the long milled RHC. In a previous investigation, $\mathrm{NaMgH}_{3}$ was observed before the formation of $\mathrm{NaBH}_{4}$, which is contrary to the reported findings with formation $\mathrm{NaBH}_{4}$ before $\mathrm{NaMgH}_{3-\mathrm{x}} \mathrm{F}_{\mathrm{x}}$. Curiously, in the long milled $\mathrm{RHC}, \mathrm{NaBH}_{4}$ and $\mathrm{NaMgH}_{3-\mathrm{x}} \mathrm{F}_{\mathrm{x}}$ reaction products form in greater amounts $(\sim 40 \mathrm{wt} \%)$, while, in the short milled system, under the same conditions, those products only appeared in minor amounts $(\sim 10 \mathrm{wt} \%)$. For the latter, it is assumed that a hydrogen containing, but purely scattering, boron rich phase (" $\mathrm{B}_{48}$ ") is responsible for the lack of $\mathrm{NaBH}_{4}$ and $\mathrm{NaMgH}_{3-\mathrm{x}} \mathrm{F}_{\mathrm{x}}$ [90].

\subsection{Challenges, Pitfalls and Deliberate Destructive Mechanochemistry}

Although mechanochemical synthesis is a widely used technique, there are challenges, pitfalls and certain aspects to consider when it comes to its destructive use. Traditional ball milling conducted in the "grinding mode" is often a continuous process lasting over many hours and may lead to significant heating of particles. With this high-energy method, it is possible to synthesize stable as well as metastable compounds [3]. To further emphasize the challenges of steel equipment and the continuous process of milling, it is worth noting that induced impurities of Fe can be as high as $4 \mathrm{wt} \%$ after extended milling intervals [92]. Materials such as WC coated vials and WC balls are used to avoid iron contamination. Nevertheless, as these are very brittle, contamination is again unavoidable.

The observations from "grinding mode" may lead to the misconception that mechanochemistry is "just" random mixing of elements, but in truth, it has become clear that complex reactions often take place. However, prolonged mechanochemical treatment in the "grinding mode" may lead to decomposition of the sample and has in fact been utilized to develop novel "deliberate destructive mechanochemistry" synthesis strategies. A concept being illustrated by synthesis of nanosized vanadium boride in a matrix of halides, which are readily dissolved and removed by water [93]. It also led to the development of a new approach to synthesize anion-substituted sodium chloride [93-95].

In several cases, a metal chloride and an alkali metal borohydride are mechanochemically treated. The reaction product reveals clear diffraction from the alkali metal chloride and some minor unidentified diffraction peaks, e.g., for the synthesis of $\mathrm{Sc}\left(\mathrm{BH}_{4}\right)_{3}$ [96], $\mathrm{V}\left(\mathrm{BH}_{4}\right)_{2}$ and $\mathrm{Cr}\left(\mathrm{BH}_{4}\right)_{2}$ [97-100]. This suggests that the sample was "over-milled" or that the synthesis product was amorphous. A mechanochemical synthesis of $\mathrm{Zn}\left(\mathrm{BH}_{4}\right)_{2}$ was also reported $[96,101]$, but the diffraction data did not allow for determination of the structure. Nonetheless, the synthesis product appears to be a mixture of $\mathrm{NaZn}_{2}\left(\mathrm{BH}_{4}\right)_{5}$ and $\mathrm{NaZn}\left(\mathrm{BH}_{4}\right)_{3}[54,55]$.

\subsubsection{Reaction Byproduct}

Meanwhile, the solvent-based synthesis of metal borohydrides has been employed for over 50 years [102]. The advantage of this method is the ability to remove the byproducts (e.g., $\mathrm{LiCl}$ ) to yield pure products, thus allowing for the accurate determination of their physical properties $[32,44,103,104]$. The detriment of the solvent-based synthesis is the possible decomposition of, for instance the $R E$ borohydride upon removal of the solvent [105]. On the contrary, mechanochemical synthesis does 
allow for the facile synthesis of these materials without complicated in vacuo manipulations and possible decomposition of the desired product [102].

\subsection{2. $\mathrm{LiBH}_{4}$ and the Influence of its Deliberate Destructive Decomposition Product}

Previous methods for the synthesis of trivalent rare earth $(R E)$ metal borohydrides are based on the reaction of $\mathrm{LiBH}_{4}$ with $R E \mathrm{Cl}_{3}$ [106,107]. The products obtained are reported to be contaminated with amorphous $\mathrm{LiBH}_{4}$ as the metathesis reaction of $\mathrm{LiBH}_{4}$ and $R E \mathrm{Cl}_{3}$ does not go to completion. Instead of a complete conversion into $R E\left(\mathrm{BH}_{4}\right)_{3}$ and $\mathrm{LiCl}$, it is plausible that some $\mathrm{LiBH}_{4}$ is among the reaction products. $\mathrm{LiBH}_{4}$ in minor amounts can be hard to observe utilizing laboratory powder X-ray diffraction (PXD) due to its weak scattering or possibly even amorphous phases.

The presence of amorphous $\mathrm{LiBH}_{4}$ has consequences for the thermal properties and chemical reactivity of samples prepared. For example, $\mathrm{La}\left(\mathrm{BH}_{4}\right)_{3}$ synthesized according to the aforementioned method forms $\mathrm{Li}_{3} \mathrm{~K}_{3} \mathrm{La}_{2}\left(\mathrm{BH}_{4}\right)_{12}$ upon the reaction with $\mathrm{KBH}_{4}$ [108]. Therefore, the focus has been on new synthetic strategies and investigations of chemical, physical and structural properties of the pure compounds. A new method to obtain solvate complexes, $R E\left(\mathrm{BH}_{4}\right)_{3} \mathrm{~S}_{(}\left(\mathrm{CH}_{3}\right)_{2}, R E=\mathrm{Pr}, \mathrm{Nd}$, and the corresponding borohydrides, $R E\left(\mathrm{BH}_{4}\right)_{3}, R E=\mathrm{Pr}, \mathrm{Nd}$, allows detailed investigation of the polymorphic transformations [109]. Although a solvate-based synthesis is reported, the activation step of the samples remains high-energy mechanochemical milling.

An intriguing detail for the understanding of the influence of amorphous $\mathrm{LiBH}_{4}$ has been reported and explains a rehydrogenation pathway of an erbium borohydride composite [47]. Recent reports have shown that in pure $\mathrm{Er}\left(\mathrm{BH}_{4}\right)_{3}$, synthesized by mechanochemical milling of $\mathrm{ErCl}_{3}+\mathrm{LiBH}_{4}$, up to $20 \%$ of the initial released hydrogen could be rehydrogenated [110]. Although an explanation of reaction products was not given, it was shown later that pure $\operatorname{Er}\left(\mathrm{BH}_{4}\right)_{3}$, from a solvent-based synthesis, does not reabsorb hydrogen, e.g., at $400{ }^{\circ} \mathrm{C}$ and 100 bar $\mathrm{H}_{2}$. Nevertheless, by mixing $50 \mathrm{wt} \% \mathrm{LiH}$ into a desorbed sample of $\operatorname{Er}\left(\mathrm{BH}_{4}\right)_{3}$ and applying similar rehydrogenation conditions as described above, $\mathrm{ErH}_{3}$ and $\mathrm{LiBH}_{4}$ were formed [47].

Summarizing, amorphous $\mathrm{LiBH}_{4}$ in minor amounts are impossible to observe in PXD but its decomposition product $\mathrm{LiH}$, is most likely the starting point for the rehydrogenation pathway reported in Ref. [47]. A RHC using this knowledge, showed that $\mathrm{Er}\left(\mathrm{BH}_{4}\right)_{3}$ with additional $\mathrm{LiH}$ and $\mathrm{LiBH}_{4}$ can have very decent rehydrogenation behavior of $88 \%$ and $83 \%$ after the second and third desorption/absorption cycles, respectively [111].

\subsubsection{Conclusions}

To finalize this section, all aforementioned investigations indicate that pressure induced transitions as well as composition are of major importance, in particular for high-energy ball milling. Ball milling can induce high pressure and mechanical stress between the reacting materials. Thus, facilitating chemical reactions, in contrast to traditional solid-state synthesis techniques, which are mainly temperature "driven", i.e., reactions occur due to cation diffusion in the solid state [112]. Previously, ball milling was mainly devoted to the preparation of alloys and solid solutions of metals, but nowadays comprises ionic, ionic/covalent and organic molecules. In some cases, novel materials are only accessible through mechanochemistry and, apparently, cannot be obtained by other means.

\section{Cryomilling-Mechanical Processing and Synthesis at Low Temperatures}

Cryomilling is used for mechanochemical processing and synthesis of materials at low temperatures. In a SPEX Freezer/Mill, the vial with powder and a stainless-steel impactor is placed in liquid nitrogen $(77 \mathrm{~K})$. The impactor is the only moving part, and it moves back and forth by an oscillating electromagnetic field. The powder is trapped between the impactor and the ends of the vial each time a collision occurs. The impact frequency is up to $30 \mathrm{~Hz}$.

When ductile metals/materials are cryomilled, the low temperature will promote embrittlement of the ductile phase, the cold welding to the milling media is limited and there will be a limited 
deviation from the nominal composition. The increased embrittlement at low temperature will also lead to reduced particle sizes and shortened diffusion paths. Cryomilling is for example used to process Mg-based alloys [113,114]. Furthermore, cryomilling is important for synthesis of metastable compounds/phases since the heat released in the wanted reaction may be absorbed by the vial before critical temperatures for thermal decomposition are reached. This implies that, compared to room temperature, the metastable compounds are less likely to decompose due to reduced mobility. One example is synthesis of the unstable borohydride $\mathrm{LiZn}_{2}\left(\mathrm{BH}_{4}\right)_{5}$ [115]. Another important example is the synthesis of aluminum hydride $\mathrm{AlH}_{3}$ (alane), and here we review and present new results of properties of $\mathrm{AlH}_{3}$ synthesized by cryomilling.

$\mathrm{AlH}_{3}$ has a high gravimetric $(10.1 \mathrm{wt} \%)$ and volumetric hydrogen density $\left(148 \mathrm{~g} \mathrm{H}_{2} / \mathrm{L}\right)$. Hydrogen can be released at moderate temperatures, which makes the compound interesting for hydrogen storage applications. $\mathrm{AlH}_{3}$ has been found to take at least six different crystal structures depending on the synthesis route: $\alpha, \alpha^{\prime}, \beta, \gamma, \delta$ and $\varepsilon$ [116-122]. $\mathrm{AlH}_{3}$ is metastable at ambient conditions, decomposing into aluminum metal and hydrogen gas at $60-80{ }^{\circ} \mathrm{C}$ [123-125]. This reaction is not reversible at moderate conditions; $\mathrm{H}_{2}$ pressure larger than $2.5 \mathrm{GPa}$ is required to rehydride $\mathrm{Al}$ powder.

$\mathrm{AlH}_{3}$ polymorphs have traditionally been synthesized by organometallic methods. Since $\mathrm{AlH}_{3}$ is not thermally stable at room temperature (RT), dehydrogenation during ball milling at ambient conditions must be avoided. When $3 \mathrm{LiAlD}_{4}+\mathrm{AlCl}_{3}$ are ball milled in a planetary ball mill at RT, small amounts of $\alpha$ - and $\alpha^{\prime}-\mathrm{AlD}_{3}$ were detected along with $\mathrm{LiCl}$ and $\mathrm{Al}$ [117]. By cryomilling $3 \mathrm{LiAlD}_{3}$ $+\mathrm{AlCl}_{3}$ in a SPEX Freezer/Mill, significant amounts of $\alpha$ - and $\alpha^{\prime}-\mathrm{AlD}_{3}$ together with $\mathrm{LiCl}$ were detected, and the quantitative phase analysis indicated a mixture of $34 \% \alpha^{\prime}-\mathrm{AlD}_{3}$ and $66 \% \alpha-\mathrm{AlD}_{3}[117]$ (see Figure 2).

Cryomilling the mixture $3 \mathrm{NaAlH}_{4}+\mathrm{AlCl}_{3}$ gave an increased total amount of alanes compared to the synthesis based on $3 \mathrm{LiAlD}_{3}+\mathrm{AlCl}_{3}$ : the ratio $\alpha^{\prime} / \alpha$ was increased to 1.04 , but the synthesized alane has lower thermal stability [126]. The ratio of polymorphs can to some extent be controlled by adding additives and seed crystals. Small amounts of $\mathrm{FeF}_{3}$ (isostructural to $\beta-\mathrm{AlH}_{3}$ and $\alpha^{\prime}$ is similar to the $\beta$ polymorph ) added to $3 \mathrm{LiAlD}_{4}+\mathrm{AlCl}_{3}$ increased the $\alpha^{\prime} / \alpha$ ratio to 1.05 [126]. $\alpha-\mathrm{AlF}_{3}$ is isostructural to $\alpha-\mathrm{AlH}_{3}$, and cryomilling $3 \mathrm{~mol} \%$ of $\mathrm{AlF}_{3}$ with $\beta-\mathrm{AlD}_{3}$ gave a significant decrease of the $\alpha^{\prime} / \alpha$ ratio, and thus highest amount of $\alpha-\mathrm{AlD}_{3}$ [127]. Additional of $\mathrm{TiF}_{3}$ lead to full decomposition to $\mathrm{Al}$.

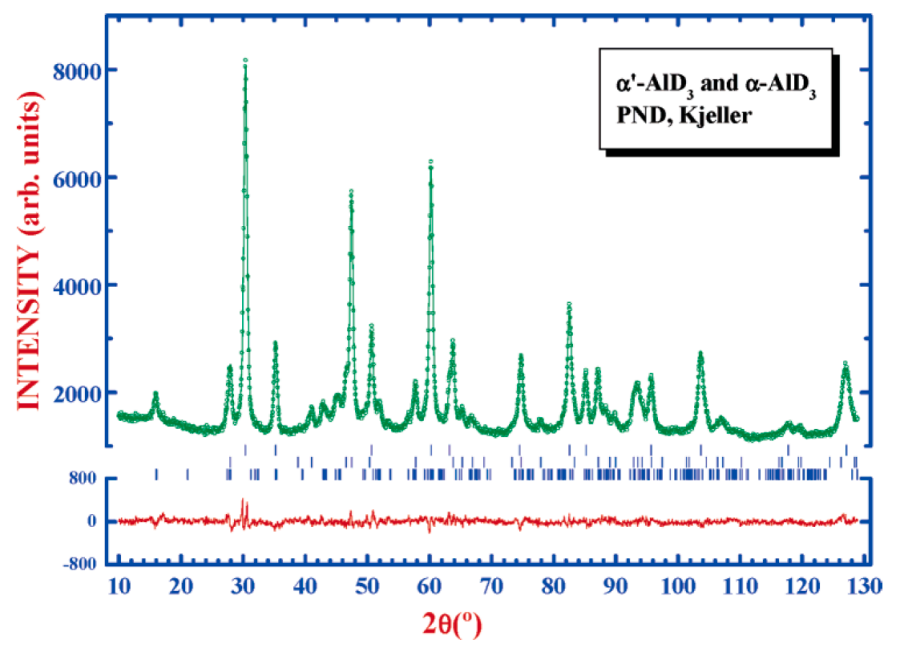

Figure 2. Observed intensities (circles) and calculated intensities from Rietveld refinements (upper line) of cryomilled $3 \mathrm{LiAlD}_{4}+\mathrm{AlCl}_{3}$ at $\mathrm{RT}$ for powder neutron diffraction (PUS, JEEP II, and IFE) data. Positions of Bragg reflections are shown with bars for $\mathrm{LiCl}, \alpha-\mathrm{AlD}_{3}$, and $\alpha^{\prime}-\mathrm{AlD}_{3}$ (from top). The difference between observed and calculated intensities is shown with the bottom line. Taken from [117]. 
Since $\alpha-\mathrm{AlH}_{3}$ takes the same structure as $\alpha-\mathrm{AlF}_{3}$ and $\alpha^{\prime}-\mathrm{AlH}_{3}$ is isostructural to $\beta-\mathrm{AlF}_{3}$, it has been investigated experimentally, by ab initio calculations and thermodynamic modeling, if fluorine anion substation can take place in $\mathrm{AlH}_{3}$ [128]. The samples were prepared by cryomilling. However, fluorine substitution does not seem feasible for the alane system, and thus not similar to F-substitution in $\mathrm{Na}_{3} \mathrm{AlH}_{6}$ [129].

To assess the potential of cryomilled $\mathrm{AlH}_{3}$ for hydrogen storage applications, tests were recently carried out with two aims: (i) gain information about reactivity and influence of passivation layers (mainly oxides) on the decomposition behavior of alane; and (ii) study the metastability of alane after partial decomposition.

Both issues are crucial for application purposes. On the one hand, it is important to know if impurities due to air exposure will cause a degradation of the material's performance or change its characteristics. On the other hand, it is of interest to know if the decomposition process continues after the temperature of the system is lowered below the onset temperature for thermal desorption.

Reactivity and passivation tests were carried out on two different sets powders: (i) as-prepared (cryomilled) alane heated from RT to $400{ }^{\circ} \mathrm{C}$; and (ii) cryomilled alane exposed to air for $24 \mathrm{~h}$ and heated from RT to $400{ }^{\circ} \mathrm{C}$.

The results of the passivation test are summarized in Figures 3 and 4, which display the DSC and TGA traces for the two samples between 25 and $250{ }^{\circ} \mathrm{C}$. The as-prepared cryomilled material (Figure 3) loses about $6.5 \mathrm{wt} \%$ of its storage capacity in the temperature region $25<T<250{ }^{\circ} \mathrm{C}$. In this case, the onset temperature for desorption, $T_{o n}$, was determined to be $121(1){ }^{\circ} \mathrm{C}$. A different cryo-milled sample passivated by air exposure for $24 \mathrm{~h}$ (Figure 4 ) shows a weight loss of about $5 \mathrm{wt} \%$ between RT and $250^{\circ} \mathrm{C}$ and displays a $T_{\text {on }}$ of $126(1){ }^{\circ} \mathrm{C}$. The shift and decrease in capacity could be explained by the formation of oxides (hydroxides) which create a surface barrier that needs to be overcome.

The reactivity tests were carried out in a fume hood by exposing as-milled and passivated powder to air. No combustion was observed after ca. $1 \mathrm{~min}$ of air exposure. Dripping water $\left(\mathrm{H}_{2} \mathrm{O}\right)$ on the air-exposed powder produced mild bubbling.

The metastability of cryomilled $\mathrm{AlH}_{3}$ was investigated by DSC-TG and by in situ synchrotron radiation powder X-ray diffraction (SR-PXD). The aim of these measurements was to test whether the desorption reaction can be controlled-i.e., stopped-if the temperature is decreased from the onset temperature for desorption down to RT.

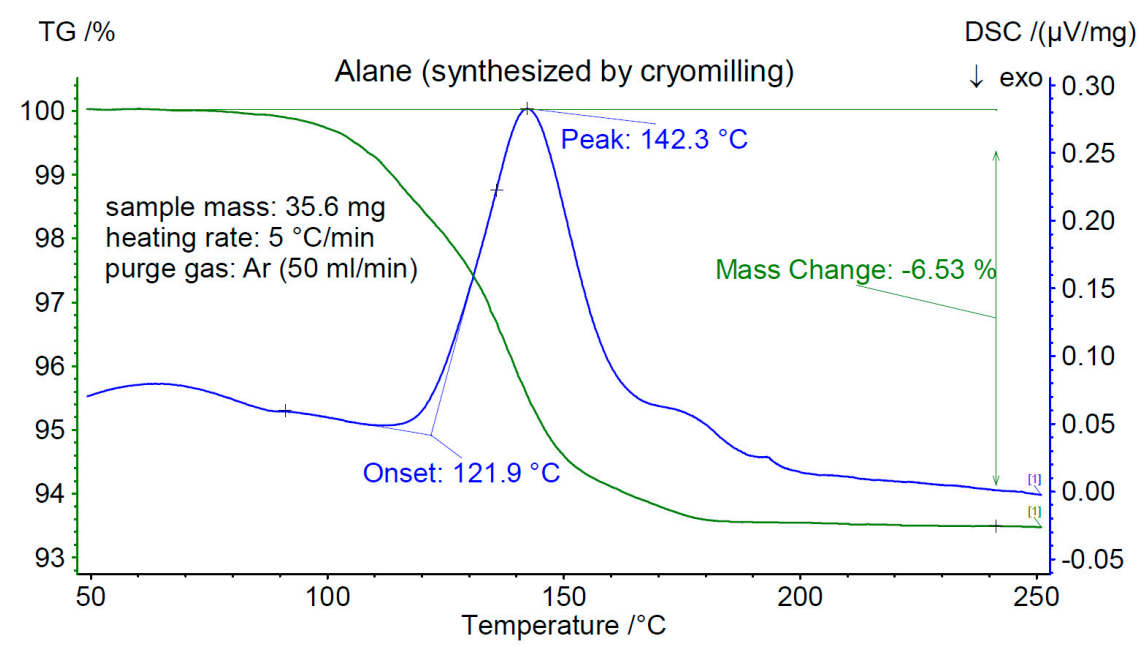

Figure 3. DSC-TGA data of a cryo-milled sample. Data are shown between RT and $250{ }^{\circ} \mathrm{C}$. 


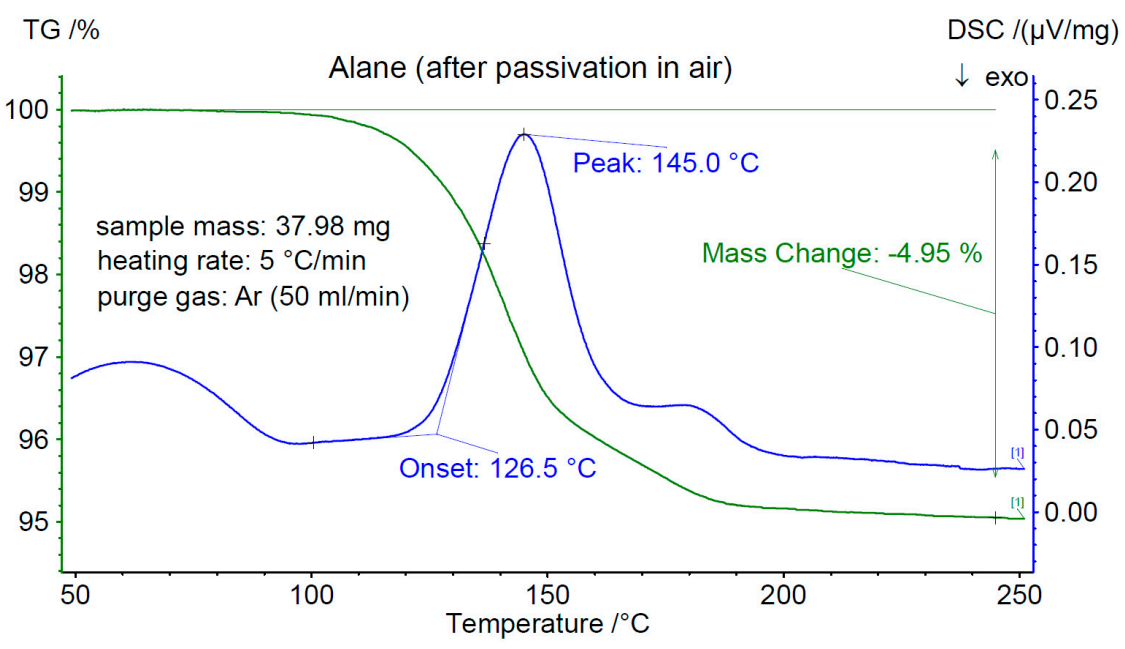

Figure 4. DSC-TGA data of a passivated sample (exposed to air for $24 \mathrm{~h}$ ). Data are shown between RT and $250^{\circ} \mathrm{C}$.

The as-synthesized cryomilled alane powder was heated with a constant heating rate $(5 \mathrm{~K} / \mathrm{min})$ at three different temperatures: at the onset temperature for desorption $T_{\text {on }} ; 10 \mathrm{~K}$ above the onset temperature $T_{o n+10 K}$; and $10 \mathrm{~K}$ or $15 \mathrm{~K}$ below the onset temperature $T_{o n-10 \mathrm{~K}}$ or $T_{\text {on-15K }}$, respectively.

DSC-TG isotherms carried out on the three samples at RT right after heating (not shown) show that the signal of the thermobalance stays constant over the duration of the isothermal measurement. This clearly indicates that there is no sign for a continuation of the desorption process after the temperature has been lowered to RT. This suggests that alane could be safely stored and that the decomposition can be fully controlled by lowering the temperature below the onset temperature, e.g., when the system is in standby mode.

Synchrotron radiation power X-ray diffraction (SR-PXD) measurements were performed at the Swiss-Norwegian Beamlines (SNBL) at the European Synchrotron Radiation Facility (ESRF) in Grenoble, France. Decomposition reactions of alane in closed boroglass capillaries, heated with a hot air blower, were followed in situ. A diffraction pattern was collected every $30 \mathrm{~s}$. As expected, the RT SR-PXD data (not shown) revealed a mixture of the phases $\alpha$ - and $\alpha^{\prime}-\mathrm{AlH}_{3}, \mathrm{LiCl}$ and Al. Heating the material from ambient temperature with a rate of $5 \mathrm{~K} / \mathrm{min}$, the onset of decomposition was found to be between 117 and $120^{\circ} \mathrm{C}$, from where the alane peaks diminish and the $\mathrm{Al}$ peaks increase in intensity. Figure $5 \mathrm{a}-\mathrm{c}$ shows the reduction of the Bragg peak intensities of $\alpha$ - and $\alpha^{\prime}-\mathrm{AlH}_{3}$ after heating at $T_{\text {on }}$, $T_{o n+10 \mathrm{~K}}$, and $T_{o n-15 \mathrm{~K}}$.

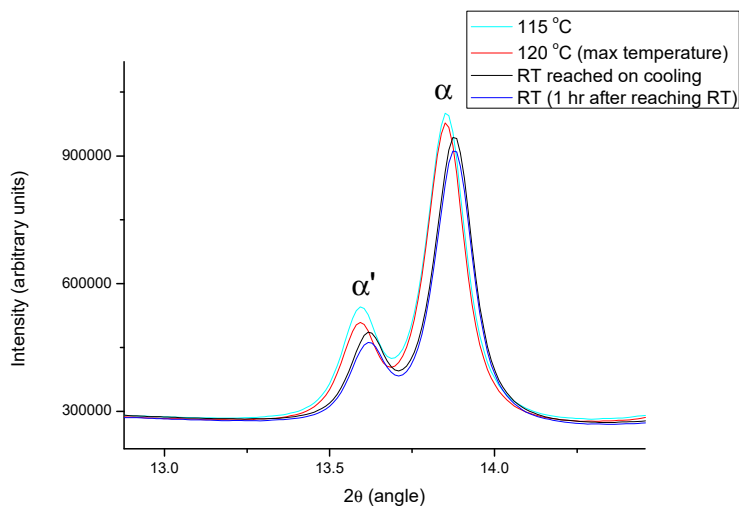

(a)

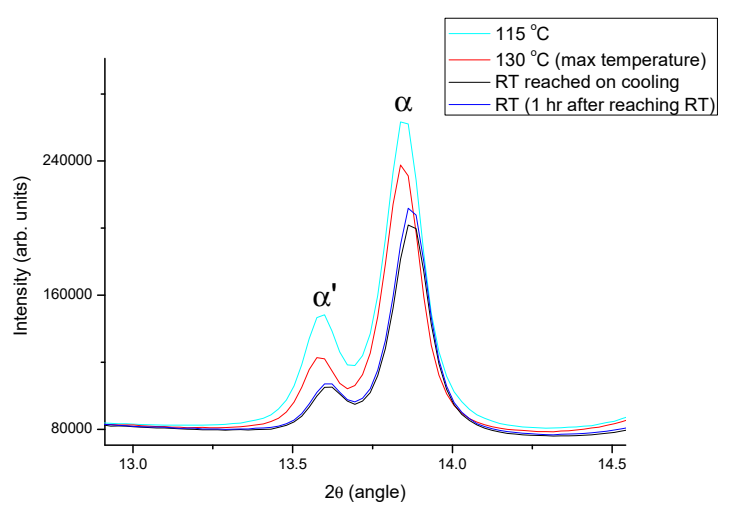

(b)

Figure 5. Cont. 


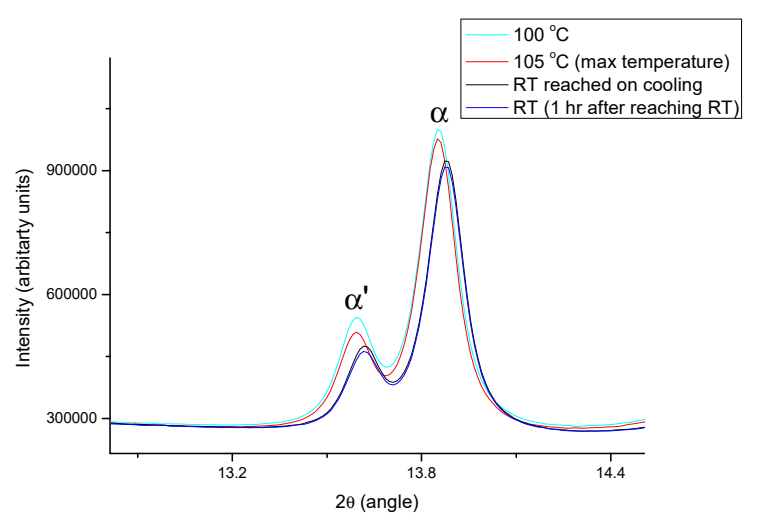

(c)

Figure 5. Bragg peaks from $\alpha$ - and $\alpha^{\prime}$-AlH3 during in-situ SR-PXD decomposition after heating at: (a) $\mathrm{T}_{\text {on }} ;$ (b) $\mathrm{T}_{\text {on }+10 \mathrm{~K}}$; and (c) $\mathrm{T}_{\text {on-15K }}$ and cooling to $\mathrm{RT}$.

As expected, the reduction is larger for the materials after heating $10 \mathrm{~K}$ above the $T_{\text {on }}$ (Figure $5 \mathrm{a}$ ). There is no significant further decrease in the $\mathrm{AlH}_{3}$ peaks after dwelling $1 \mathrm{~h}$ at $\mathrm{RT}$. It is worth pointing out that a reduction of the $\mathrm{AlH}_{3}$ peaks is also observed for the sample heated to $15 \mathrm{~K}$ below $T_{\text {on }}$ (Figure $5 \mathrm{c}$ ), thus indicating that some desorption takes place also below the onset temperature determined by heating with $5^{\circ} \mathrm{C} / \mathrm{min}$. Furthermore, there was no appreciable change during the 1 -h isotherm at RT.

In summary, the tests described above clarified that the reactivity of the powder when exposed to air is limited and passivation in air does not change significantly the reactivity, while it lowers the amount of hydrogen released during desorption. Furthermore, the decomposition process of $\mathrm{AlH}_{3}$ stops when the temperature of the system is lowered below the onset temperature for thermal desorption. The latter finding is technologically relevant for potential applications in solid-state hydrogen storage.

\section{Formation and Defect Generation of Lightweight Hydrides by Mechanochemistry under Hydrogen Gas}

Mechanochemistry under hydrogen gas is a versatile synthesis route for the formation of hydride compounds. Indeed, many families of compounds, such as binary and ternary metal hydrides as well as Mg- and Al-complex hydrides, can be directly synthesized by mechanochemistry of their constituting metals under hydrogen gas [5]. Hydride formation is achieved for compounds that are thermodynamically stable at the pressure $(P)$ and temperature $(T)$ conditions at which the solid gas reactions occur inside the milling jar. As these experiments are performed at high pressure and temperature and with vials under mechanical stress, it is important to have certified equipment that meets all safety regulations.

The concept of mechanochemistry under pressure is supported by the work of Zhang et al. [130] showing the relevance of $(P, T)$ local conditions in mechanochemistry. They studied the Mg-Si-H system by reactive ball milling starting from $2 \mathrm{Mg}$, and Si powders as reactants under a hydrogen pressure of $9 \mathrm{MPa}$. Depending on the milling energy (tuned by changing the rotation speed of the vials), they obtained two different final equilibrium states, either $\mathrm{Mg}_{2} \mathrm{Si}$ or $2 \mathrm{MgH}_{2}+\mathrm{Si}$ at high and low rotation speeds, respectively. Such comportment was interpreted by the change of the local temperature which increases with milling speed at the milling impact.

Beside the synthesis of stable hydride phases, whose formation can also be attained by the classical route of thermally driven solid-gas reaction, mechanochemistry under hydrogen gas opens the way to the formation of metastable phases thanks to severe plastic deformation effects induced by mechanical energy. Recent studies on the formation of lightweight imide and amide $\mathrm{Li}-(\mathrm{Mg})-\mathrm{N}-\mathrm{H}$ starting from $\mathrm{Li}_{3} \mathrm{~N}$ (and Mg) as initial solid reactants are reviewed here [131,132]. These compounds deserve high interest as hydrogen storage materials [133,134] as well as Li-ion conductors [135-137]. 
Mechanochemistry of commercial $\mathrm{Li}_{3} \mathrm{~N}$ under hydrogen gas $\left(P_{\mathrm{H} 2}=9 \mathrm{MPa}\right)$ entails the consecutive formation of lithium imide $\left(\mathrm{Li}_{2} \mathrm{NH}\right)$ and lithium amide $\left(\mathrm{LiNH}_{2}\right)$ according to the reaction scheme given by Reactions (20) and (21) [132]:

$$
\begin{gathered}
\mathrm{Li}_{3} \mathrm{~N}+\mathrm{H}_{2} \rightarrow \mathrm{Li}_{2} \mathrm{NH}+\mathrm{LiH} \\
\mathrm{Li}_{2} \mathrm{NH}+\mathrm{LiH}+\mathrm{H}_{2} \rightarrow \mathrm{LiNH}_{2}+2 \mathrm{LiH}
\end{gathered}
$$

As shown in Figure 6, the hydrogen uptake curve monitored during mechanochemistry reveals that the full hydrogenation is accomplished in less than $2.5 \mathrm{~h}$ of milling time $t_{m}$ and consists in two steps. Hydrogen uptake is linear during the first step. This has been attributed to the constant rate of mechanical collisions. X-ray dffraction analysis showed that the first step comprises the transformation of the polymorph $\alpha-\mathrm{Li}_{3} \mathrm{~N}$ (S.G. P6/mmm) into the $\beta-\mathrm{Li}_{3} \mathrm{~N}$ (S.G. $P 6_{3} / \mathrm{mmc}$ ) metastable phase and the reaction of the latter with hydrogen to form lithium imide (Reaction 20). High local mechanical pressure at impact between $\alpha-\mathrm{Li}_{3} \mathrm{~N}$ powder and milling tools lead to the formation of $\beta-\mathrm{Li}_{3} \mathrm{~N}$, which is the stable polymorph of $\mathrm{Li}_{3} \mathrm{~N}$ at $P>0.6 \mathrm{GPa}$ [138]. The metastable conditions of $\beta-\mathrm{Li}_{3} \mathrm{~N}$ are close to those of the high-pressure orthorhombic $\gamma-\mathrm{MgH}_{2}$ polymorph (stable phase at $P>2 \mathrm{GPa}$ [139]), which has been widely observed during mechanical milling of magnesium hydride [140,141]. As for the second reaction step (Reaction 21), leading to lithium amide formation, the hydrogen uptake curve has a sigmoidal shape. This is characteristic of Avrami's nucleation and growth processes [142]. Moreover, a detailed kinetic analysis based on solid-state models indicates that amide formation is controlled by a one-dimensional Li-vacancy mechanism [132]. Structural data support this analysis and evidence formation of mixed imide/amide $\mathrm{Li}_{2-x} \mathrm{NH}_{1+x}$ compounds as intermediates. Lithium imide and amide phases formed by mechanochemistry under hydrogen gas crystallize in the low nanocrystalline range with crystal size of $10 \pm 2 \mathrm{~nm}$.

Phase and structural evolution during mechanochemistry of $\mathrm{Li}_{3} \mathrm{~N}$ under hydrogen gas shows clear differences as compared to the thermally driven solid-gas reaction. First, in the mechanochemical route, formation of intermediate phase $\mathrm{Li}_{4} \mathrm{NH}$ at low hydrogen content is not observed. This "quasi-imide" $\mathrm{Li}_{4} \mathrm{NH}$ phase has however been detected by in-situ neutron diffraction at the early stage of hydrogenation during thermally driven reaction at $250{ }^{\circ} \mathrm{C}$ [143] Second, the hydrogenation path by mechanochemistry at $P_{\mathrm{H} 2}=9 \mathrm{MPa}$ follows a two-step reaction (Reactions (20) and (21)), whereas, for the thermally-driven reaction $\left(\sim 200-250{ }^{\circ} \mathrm{C}\right)$, a single step is observed also using elevated pressures $\left(P_{H 2} \approx 1 \mathrm{MPa}\right)$. The latter result has been evidenced in several in-situ neutron diffraction studies $[144,145]$.

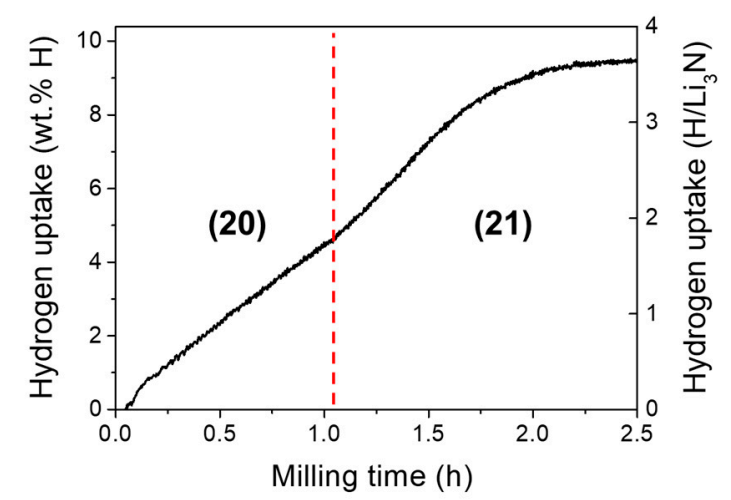

Figure 6. In situ hydrogen absorption during the mechanochemistry of $\mathrm{Li}_{3} \mathrm{~N}$ powder under hydrogen gas $\left(P_{H 2}=9 \mathrm{MPa}\right)$. The vertical dashed line shows the discontinuity in the uptake curve that reflects the two reaction Reactions (20) and (21) associated with the formation of lithium imide (left) and amide (right) compounds. Reproduced from Ref. [137] with permission from the PCCP Owner Societies.

The addition of $\mathrm{Mg}$ to the $\mathrm{Li}-\mathrm{N}-\mathrm{H}$ system deserves particular interest since a high hydrogen amount $(5.6 \mathrm{wt} \%)$ can potentially be reversibly stored at normal conditions of pressure and temperature 
in the Li-Mg-N-H system [134]. To gain access to this system by mechanochemistry, lithium nitride and magnesium in molar ratio 2:1 were milled under hydrogen gas. The in situ hydrogen uptake curve displayed in Figure 7 reflects, as in the previous case, two consecutive reactions leading to full absorption in $t_{m} \approx 2 \mathrm{~h}$ [146]. By structural analysis of deuterated compounds [131], they were assigned to the reaction scheme:

$$
\begin{gathered}
2 \mathrm{Li}_{3} \mathrm{~N}+\mathrm{Mg}+2 \mathrm{H}_{2} \rightarrow \mathrm{Li}_{3} \mathrm{MgN}_{2} \mathrm{H}+3 \mathrm{LiH} \\
\mathrm{Li}_{3} \mathrm{MgN}_{2} \mathrm{H}+3 \mathrm{LiH}+3 \mathrm{H}_{2} \rightarrow \mathrm{Mg}\left(\mathrm{NH}_{2}\right)_{2}+6 \mathrm{LiH}
\end{gathered}
$$

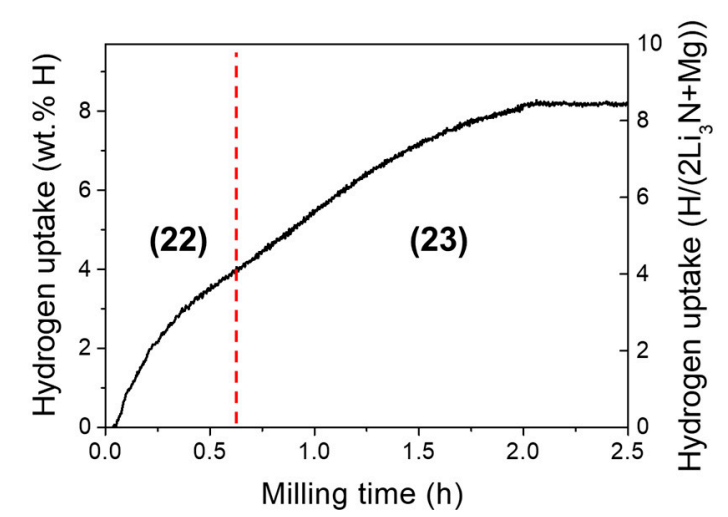

Figure 7. In situ hydrogen absorption during the mechanochemistry of $2 \mathrm{Li}_{3} \mathrm{~N}+\mathrm{Mg}$ mixed powder under hydrogen gas $\left(P_{\mathrm{H} 2}=9 \mathrm{MPa}\right)$. The vertical dashed line shows the discontinuity in the uptake curve that reflects the two reaction Reactions (22) and (23) associated with the formation of cation-mixed nitride/imide $\mathrm{Li}_{3} \mathrm{MgN}_{2} \mathrm{H}$ (left) and magnesium amide $\mathrm{Mg}\left(\mathrm{NH}_{2}\right)_{2}$ (right) compounds. Reprinted by permission from Springer, Ref. [146].

The Reaction (22) leads to the formation of a cation-mixed nitride/imide $\mathrm{Li}_{3} \mathrm{MgN}_{2} \mathrm{H}$ compound. It crystallizes in anti-fluorite type structure (S.G. Fm-3m) with local coexistence of $\mathrm{N}^{3-}$ and $[\mathrm{NH}]^{2-}$ ions on a face-centered cubic lattice as well as random occupancy of $\mathrm{Li}$ and $\mathrm{Mg}$ cations at tetrahedral sites. In fact, as depicted in Figure 8, the structure of $\mathrm{Li}_{3} \mathrm{MgN}_{2} \mathrm{H}$ can be regarded as an intermixing of the crystal structures of high-temperature disordered polymorphs of anti-fluorite type LiMgN nitride and $\mathrm{Li}_{2} \mathrm{NH}$ imide. Such a high level of structural disorder suggests that $\mathrm{Li}_{3} \mathrm{MgN}_{2} \mathrm{H}$ is a metastable compound whose existence is driven by mechanical deformations induced by milling. The Reaction (23) leads to the formation of long-range disordered (i.e., amorphous form) magnesium amide $\mathrm{Mg}\left(\mathrm{NH}_{2}\right)_{2}$ compound. The metastable amorphous phase $\mathrm{Mg}\left(\mathrm{NH}_{2}\right)_{2}$ crystallizes by thermal annealing on heating above $425 \mathrm{~K}$ (tetragonal S.G. $I 4_{1} / \mathrm{acd}$ ).

To summarize, mechanochemical synthesis of lightweight imide/amide $\mathrm{Li}-(\mathrm{Mg})-\mathrm{N}-\mathrm{H}$ compounds using $\mathrm{Li}_{3} \mathrm{~N}$ (and $\mathrm{Mg}$ ) and hydrogen as initial reactants is accompanied by severe defect generation: creation of vacancies, short-range and long-range atomic disorder and metastability of high-temperature or high -pressure phases. This leads to the formation of novel phases such as high-pressure polymorphs $\left(\beta-\mathrm{Li}_{3} \mathrm{~N}\right)$, locally disordered compounds $\left(\mathrm{Li}_{3} \mathrm{MgN}_{2} \mathrm{H}\right)$ and long-range disorder compounds (amorphous $\left.\mathrm{Mg}\left(\mathrm{NH}_{2}\right)_{2}\right)$. 


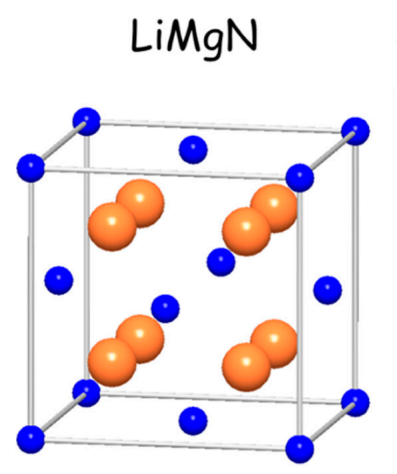

$8\left(\mathrm{Li}_{0.5}, \mathrm{Mg}_{0.5}\right), \mathbf{4 N}$

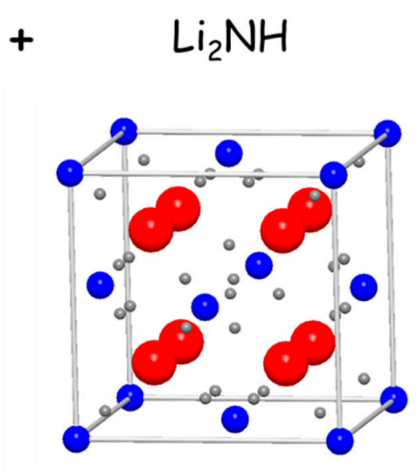

$8 \mathrm{Li}, 4 \mathrm{~N}, 4 \mathrm{H}$
$=\mathrm{Li}_{3} \mathrm{MgN} \mathrm{N}_{2} \mathrm{H}$

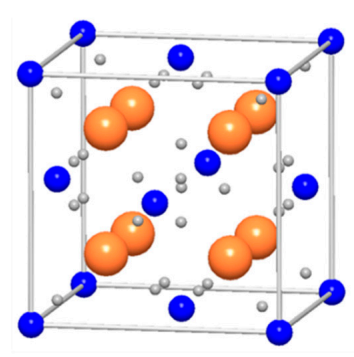

$8\left(\mathrm{Li}_{0.75}, \mathrm{Mg}_{0.25}\right), 4 \mathrm{~N}, 2 \mathrm{H}$

Figure 8. Crystal structure of cation-mixed nitride/imide $\mathrm{Li}_{3} \mathrm{MgN}_{2} \mathrm{H}$ as an intermixing of high temperature anti-fluorite-type polymorphs $\mathrm{LiMgN}$ and $\mathrm{Li}_{2} \mathrm{NH}$.

\section{High-Pressure Torsion}

High-pressure torsion (HPT) is currently one of the most popular severe plastic deformation (SPD) techniques to produce bulk nanostructured materials with a large fraction of lattice defects and enhanced functional properties $[147,148]$. In the HPT method, intense shear strain is induced in a bulk disc or powder sample by compressing the material between two anvils under high pressure and concurrent rotating the anvils with respect to each other [147,148]. Kosadume et al. in 2007 [149] conducted the first experimental study on the effect of HPT processing on the hydrogen storage properties. This study together with several other reports [150-161] confirmed the significance of HPT processing on improvement of hydrogen storage kinetics. As shown in Figure 9, this improvement in kinetics is sometimes accompanied by a reduction in hydrogen storage capacity in the first hydrogenation cycle [160]. The impact of HPT processing on hydrogen storage properties is not limited to fast kinetics, and the method can significantly enhance the activation and air resistivity, especially in difficult-to-activate Ti-based materials [159,162-171]. Moreover, the shearing nature of the deformation in HPT, together with enhanced defect-induced atomic diffusion, provide a unique opportunity for making composites $[156,158]$ and for intermixing of elements to synthesize new phases even in the immiscible systems [166,172-175]. One advantage of the HPT processing, when applied on powder samples, is that the method is conducted in a very clean way compared to high-energy ball milling that usually involves some contamination from the atmosphere or tooling. Here, the significance of microstructural and structural features induced by HPT processing is discussed on hydrogen storage properties.

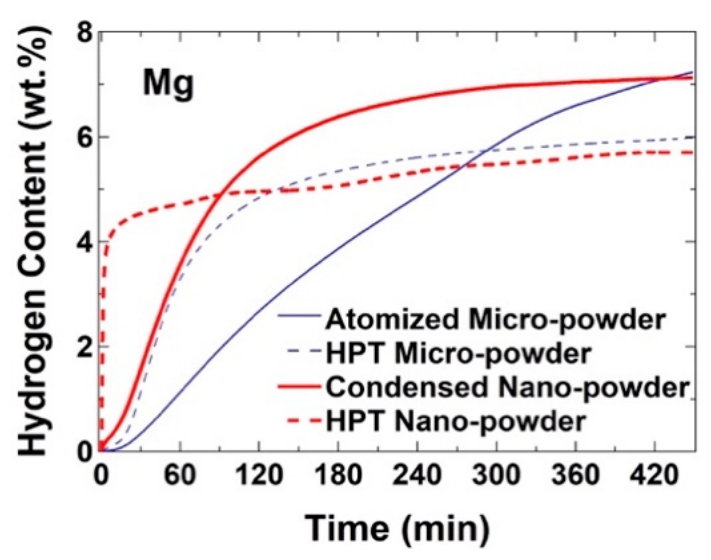

Figure 9. First hydrogen absorption kinetics measured at $673 \mathrm{~K}$ under a hydrogen pressure of $3.5 \mathrm{MPa}$ for $\mathrm{Mg}$ micro-sized atomized powder and nano-sized condensed powder before and after HPT processing [160] (reproduced with permission). 


\subsection{Significance of Grain Boundaries}

The best example of the effect of HPT on activation and air resistivity was reported for TiFe intermetallic and for Ti-based hydrogen storage materials [159,162-167]. TiFe was first introduced as a hydrogen storage material by Reilly and Wiswall in 1974 [176]. Although TiFe can thermodynamically store hydrogen at room temperature, its hydrogenation occurs only after an activation process at high temperature and/or high pressure [176]. Moreover, the thermally activated material is deactivated quickly once it is exposed to air because of intense surface oxidation. However, the HPT-processed TiFe can reversibly absorb and desorb hydrogen at room temperature without any activation treatment even after 400-day storage in air [159]. As shown in Figure 10a, it was suggested that the main mechanism for the HPT-induced activation is due to the formation of a large fraction of grain boundaries as pathways for hydrogen [162]. This mechanism was confirmed by further experiments showing that the activation pressure is reduced by the introduction of grain boundaries or by decreasing the grain size in samples processed by thermal annealing [159], grove rolling [163], HPT [159] and ball milling [177], as summarized in Figure 10b.

(a)

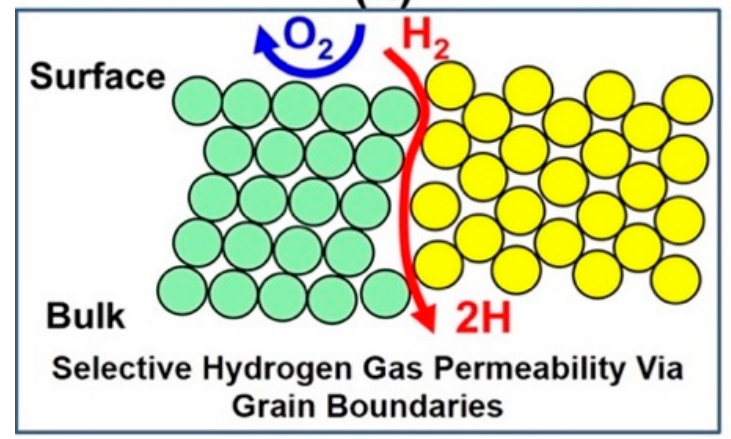

(b)

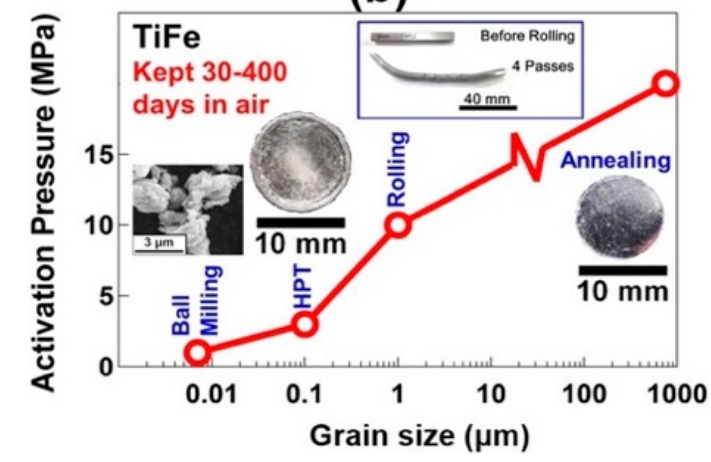

Figure 10. (a) Schematic illustration of activation mechanism by grain boundaries; and (b) variations of hydrogen activation pressure at room temperature against grain size for TiFe processed by annealing, groove rolling, HPT and ball milling [171] (reproduced with permission).

\subsection{Significance of Dislocations}

When a conventionally fabricated as-cast sample is exposed to hydrogen, large fractions of dislocations are usually formed during the first hydrogenation cycles $[178,179]$. It was suggested that, in addition to the formation of powder particles (during pulverization), the formation of dislocations in the first cycles is one of the reasons that the material can uptake hydrogen more easily in the following cycles due to dislocation-assisted hydrogen transport and metal hydride phase transformations [178,179]. It is then expected that the introduction of dislocations in the initial materials can facilitate the hydrogen uptake. Images taken by transmission electron microscopy (TEM) presented in Figure 11 show the formation of a large fraction of dislocations in a HPT-synthesized Ti-V alloy with the bcc (body-centered cubic) structure [166]. 

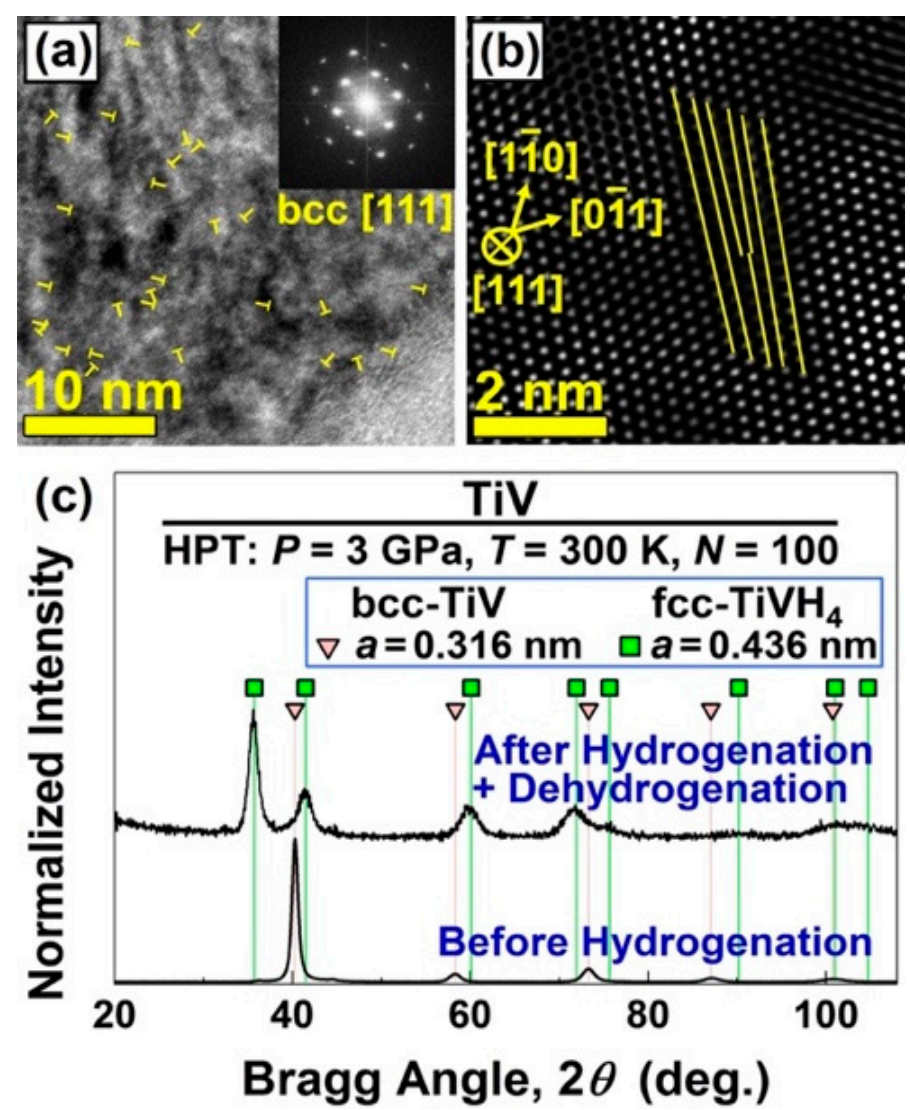

Figure 11. (a) TEM image of edge dislocations marked with T; (b) lattice image of a dislocation; and (c) XRD profile before and after hydrogenation and dehydrogenation at $303 \mathrm{~K}$ under $0.001-10 \mathrm{MPa}$ hydrogen pressure for Ti-V alloy synthesized by HPT [166] (reproduced with permission).

Although the Ti-V alloys cannot usually absorb hydrogen without a sophisticated activation treatment $[180,181]$, the HPT-processed Ti-V alloy with a large fraction of dislocation fully transforms to a $\mathrm{TiVH}_{4}$ hydride with the fcc (face-centered cubic) structure after two hydrogenation/dehydrogenation cycles at room temperature, as shown in the X-ray diffraction (XRD) pattern of Figure 11c. Here, it should be noted that the activation of Ti-V-based alloys by introduction of dislocations and grain boundaries can undesirably deteriorate their hydrogen storage reversibility [167], as discussed below.

\subsection{Significance of Stacking Faults}

As shown in Figure 12a, stacking faults coupled with partial dislocations produce atomic pathways, which may be effective to transport hydrogen [157]. To investigate the effect of stacking faults on hydrogen storage performance, stacking faults were introduced in an $\mathrm{Mg}_{2} \mathrm{Ni}$ intermetallic by HPT processing followed by thermal annealing at $673 \mathrm{~K}$ [157]. Figure 12b shows a representative stacking fault compared with the ideal ABCABC stacking. As shown in Figure 12c while the coarse-grained sample with large fractions of stacking faults absorb $2 \mathrm{wt} \%$ of hydrogen within a few minutes, the sample without stacking faults exhibits very slow hydrogenation kinetics [157]. 


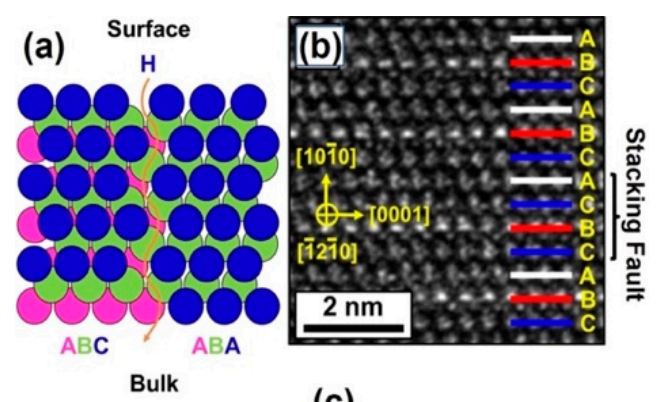

(c)

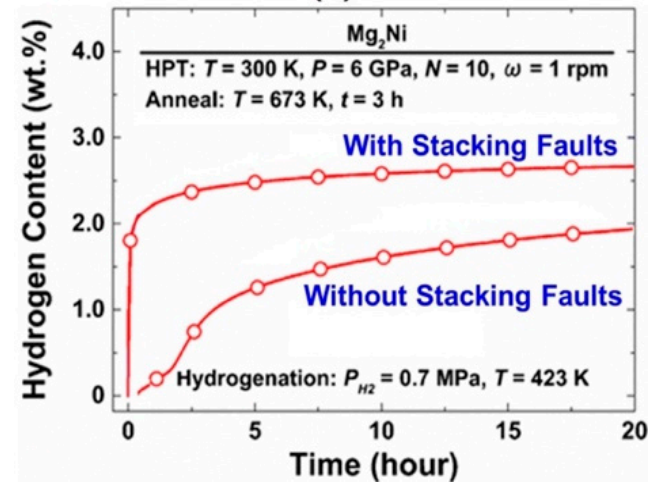

Figure 12. (a) Illustration of stacking fault effects as pathways for hydrogen; (b) TEM lattice image of a stacking fault in $\mathrm{Mg}_{2} \mathrm{Ni}$ after HPT processing followed by annealing; and (c) hydrogenation kinetic curves at $423 \mathrm{~K}$ under initial hydrogen pressure of $0.7 \mathrm{MPa}$ for coarse-grained $\mathrm{Mg}_{2} \mathrm{Ni}$ with and without stacking faults [157] (reproduced with permission).

\subsection{Significance of Localized Amorphization}

Amorphous regions are considered as fully disordered regions and can act as pathways for hydrogen permeation [182]. In an attempt to activate the $\mathrm{TiFe}_{0.85} \mathrm{Mn}_{0.15}$ intermetallics [165], nano-sized amorphous regions were introduced by HPT processing in the materials, as shown in TEM lattice image and corresponding selected-area electron diffraction (SAED) pattern with a hallo ring in Figure 13a. As shown in Figure 13b, while the as-cast material does not absorb hydrogen at room temperature in agreement with earlier publications $[183,184]$, partial amorphization by HPT leads to activation of material with fast hydrogenation kinetics. It should be noted that other studies showed that even amorphous alloys become more active with application of HPT processing because of the formation of glass/glass or glass/crystal boundaries [154,159]. For example, while the $\mathrm{Mg}_{65} \mathrm{Ce}_{10} \mathrm{Ni}_{20} \mathrm{Cu}_{5}$ amorphous alloy hardly absorb hydrogen after melt spinning, it becomes active after HPT processing and absorbs hydrogen at $393 \mathrm{~K}[159]$. 

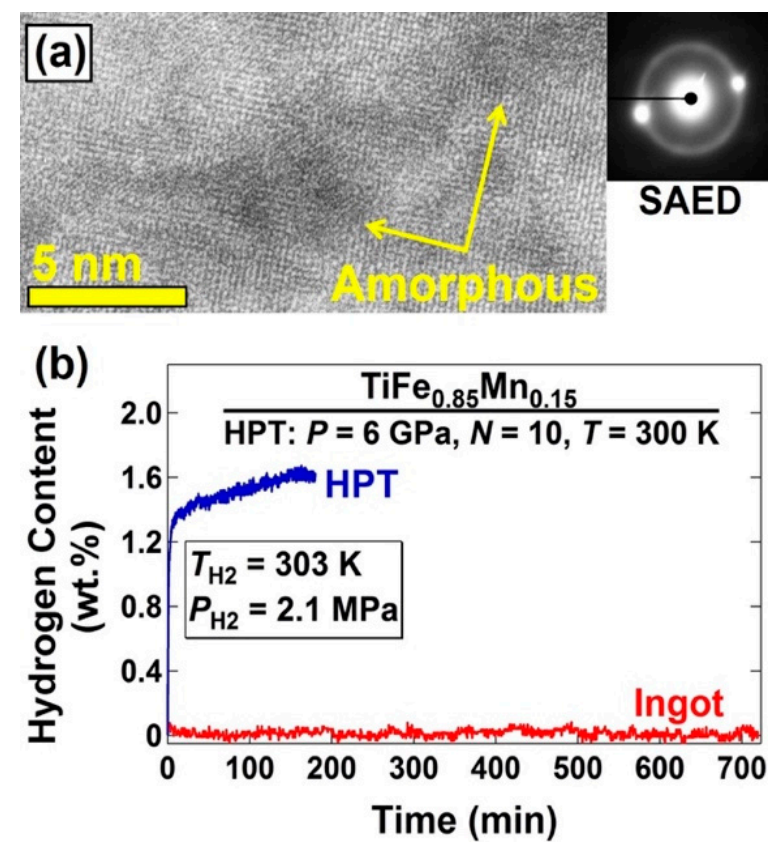

Figure 13. (a) TEM image and corresponding SEAD pattern with nano-sized amorphous regions indicated by arrows; and (b) hydrogenation kinetic curves for $\mathrm{TiFe}_{0.85} \mathrm{Mn}_{0.15}$ after ingot casting and HPT processing [165] (reproduced with permission).

\subsection{Significance of Phase Transformation}

Severe shear straining, high pressure, supersaturated fraction of lattice defects and defect-induced atomic diffusion during HPT processing, make the method an effective tool to control phase transformations [147,148]. Emami et al. [174] showed that the HPT process combined with a subsequent thermal treatment is quite effective to synthesize a large variety of stable Mg-based intermetallics from elemental powder mixtures [174]. It was shown that the method is also effective to synthesize new metastable phases even from immiscible systems [170]. Table 2 summarizes formation of metastable phases from elemental powders in several systems by HPT processing. Among these metastable phases, a $\mathrm{Mg}_{4} \mathrm{NiPd}$ alloy with the $\mathrm{CsCl}$-type crystal structure can reversibly absorb and desorb hydrogen at room temperature in good agreement with the predictions of first-principle calculations [168].

Table 2. Formation of metastable phases in various Ti-based and Mg-based systems by HPT processing.

\begin{tabular}{ccc}
\hline System & Metastable Phase(s) & Ref. \\
\hline $\mathrm{Ti}-\mathrm{V}$ & bcc & {$[166]$} \\
$\mathrm{Ti}-\mathrm{Nb}$ & bcc & {$[172]$} \\
$\mathrm{Mg}-\mathrm{Al}$ & amorphous & {$[174]$} \\
$\mathrm{Mg}-\mathrm{Zn}$ & amorphous & {$[174]$} \\
$\mathrm{Mg}-\mathrm{Sn}$ & Hcp & {$[174]$} \\
$\mathrm{Mg}-\mathrm{Ti}$ & bcc, hcp, fcc & {$[173]$} \\
$\mathrm{Mg}-\mathrm{Zr}$ & bcc, hcp, fcc & {$[175]$} \\
$\mathrm{Mg}-\mathrm{V}$ & bcc & {$[169]$} \\
$\mathrm{Mg}-\mathrm{V}-\mathrm{Ni}$ & bcc & {$[170]$} \\
$\mathrm{Mg}-\mathrm{V}-\mathrm{Pd}$ & bcc, CsCl-type & {$[170]$} \\
$\mathrm{Mg}-\mathrm{V}-\mathrm{Sn}$ & CsCl-type & {$[170]$} \\
$\mathrm{Mg}-\mathrm{V}-\mathrm{Cr}$ & bcc & {$[169]$} \\
$\mathrm{Mg}-\mathrm{Ni}-\mathrm{Sn}$ & amorphous & {$[170]$} \\
$\mathrm{Mg}-\mathrm{Ni}-\mathrm{Pd}$ & CsCl-type & {$[168]$} \\
\hline
\end{tabular}




\section{Surface Modification by Mechanical Attrition Treatment}

Compared to an appreciable number of publications on the effect of SPD processing on hydrogen storage properties, there have been quite limited attempts to modify the hydrogen storage properties by surface treatment methods [167]. In most of the SPD methods, nanostructures with large fractions of lattice defects are generated all through the bulk [147]. However, in surface treatment methods, lattice defects and nanostructure are generated only on the surface either mechanically [185] or by beam-assisted processing [186]. Among various surface treatment techniques, the surface mechanical attrition treatment (SMAT) [187], which is also known as ultrasonic shot peening [188] or severe shot peening [189], has received significant attention to produce gradient structures (nanostructures on the surface and coarse grains in bulk) $[187,190]$. In this method, the surface is treated by metallic shots impacting the surface at velocities that can reach about $10 \mathrm{~m} / \mathrm{s}$ [191,192]. It therefore bears some similarities with the high energy ball milling technique. However, the sample in SMAT is in the form of bulk plates which can be processed continuously without any limitation in the sample length. This makes the method appropriate for potential commercial applications. Moreover, as discussed below, the SMAT methods can be used as a scientific tool to have more insights into the role of surface defects and gradient structure on hydrogen storage properties.

\section{Significance of Surface Defects and Gradient-Structure}

In an attempt to understand the significance of gradient structures on hydrogen storage, two types of microstructure were produced in a $\mathrm{Ti}_{10} \mathrm{~V}_{75} \mathrm{Cr}_{15}$ alloy with the bcc structure [167]. First, as illustrated by the electron back scattering diffraction (EBSD) analysis given in Figure 14, a gradient structure was produced by SMAT having a higher density of structural defects towards the surface (see large fraction of low angle grain boundaries and high internal misorientation on the treated surface in Figure $14 \mathrm{~b}, \mathrm{c}$, respectively). Second, a uniform nanostructure all through the bulk was produced by HPT. Here, it should be noted that the Ti-V-Cr alloy was intentionally selected for this study because it can thermodynamically absorb and desorb $\sim 2 \mathrm{wt} \%$ of hydrogen at room temperature [193], but it suffers from two drawbacks: (i) it needs a thermal treatment at high temperatures for initial activation [194,195]; and (ii) its reversibility is degraded with the introduction of lattice defects [196-198].

Figure 15 shows the pressure-composition-temperature (PCT) isotherms for samples processed by: (a) SMAT; and (b) HPT (PCT was conducted at $303 \mathrm{~K}$ for the first two cycles and at $353 \mathrm{~K}$ for the third cycle). Although Ti-V-Cr alloy after both SMAT and HPT processing interestingly absorbs hydrogen without any activation treatment, only the SMAT-processed alloy exhibits $\sim 2 \mathrm{wt} \%$ hydrogen storage reversibility. The poor reversibility after HPT processing confirms that the presence of lattice defects such as dislocations and grain boundaries in the bulk can significantly degrade the reversibility of this specific alloy, in good agreement with some earlier reports [196-198].

However, as schematically shown in Figure 16 for the gradient structure produced by SMAT, the lattice defects and cracks formed on the surface activate the materials by acting as pathways for hydrogen transport while the bulk of material—which still has coarse grains with lower density of lattice defects-can store hydrogen reversibly. The current results provide new insight into the importance of surface defects on activation. 

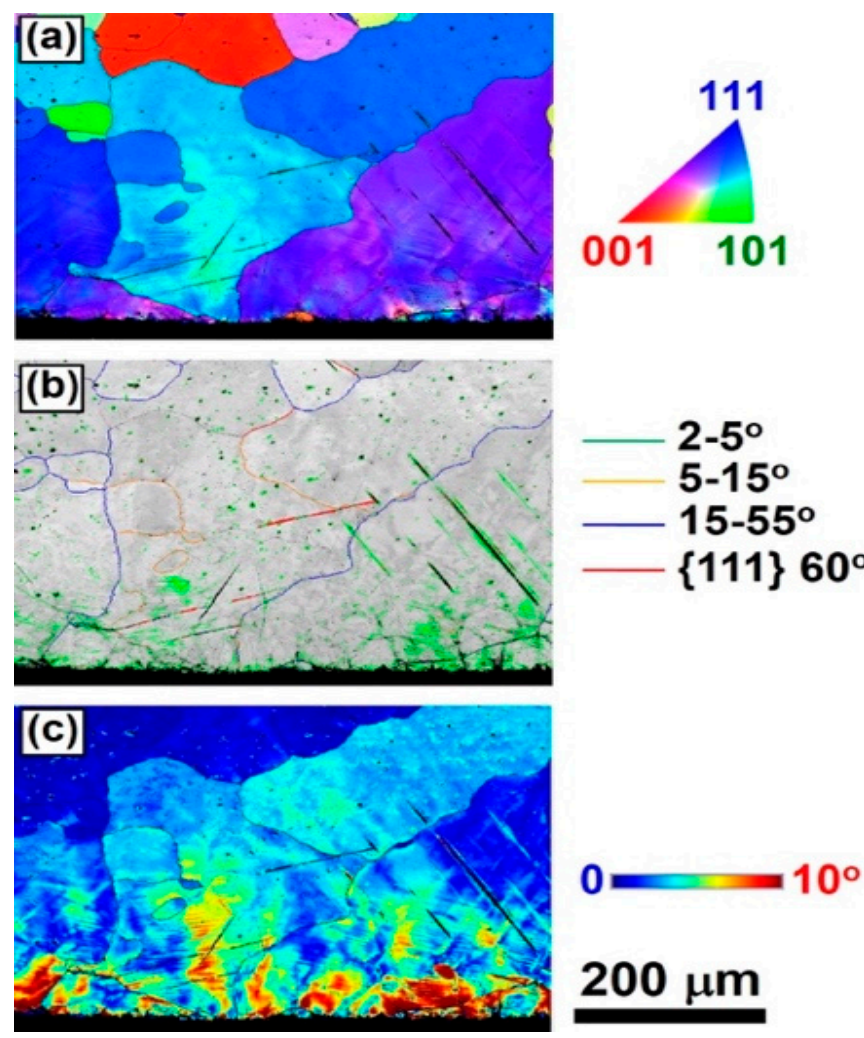

\section{$200 \mu \mathrm{m}$}

Figure 14. EBSD analysis of the gradient microstructure seeing on the cross section of a $\mathrm{Ti}_{10} \mathrm{~V}_{75} \mathrm{Cr}_{15}$ after SMAT processing: (a) orientation map; (b) grain boundary distribution; and (c) internal misorientation. Treated surface is at bottom [167] (reproduced with permission).
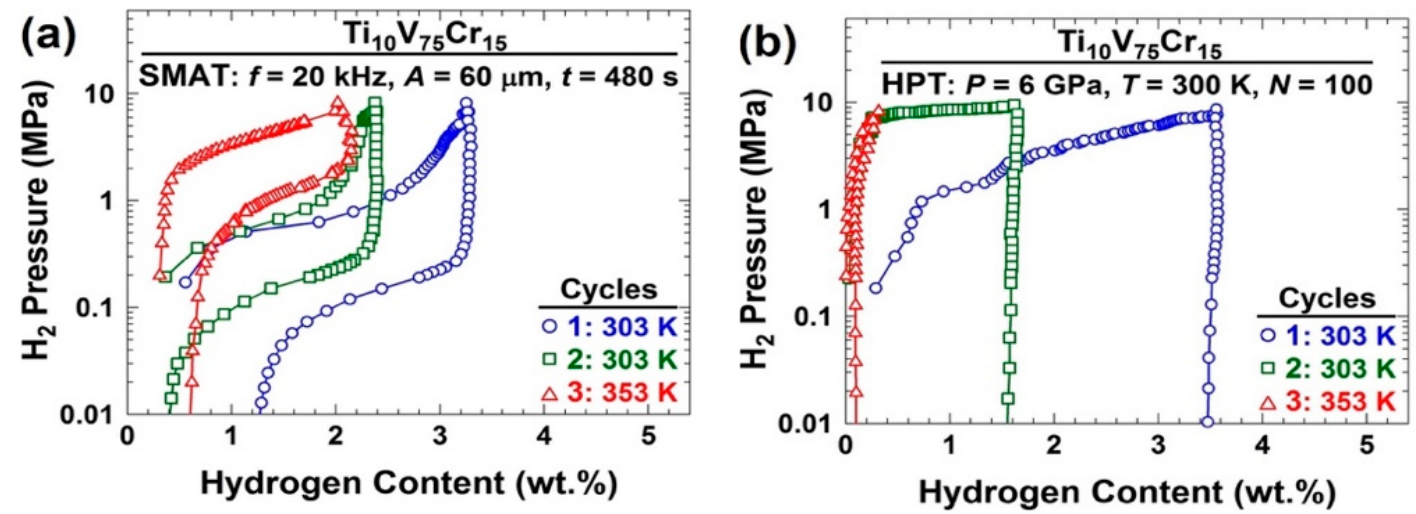

Figure 15. PCT isotherms at 303-353 $\mathrm{K}$ for $\mathrm{Ti}_{10} \mathrm{~V}_{75} \mathrm{Cr}_{15}$ after: (a) SMAT; and (b) HPT [167] (reproduced with permission). 


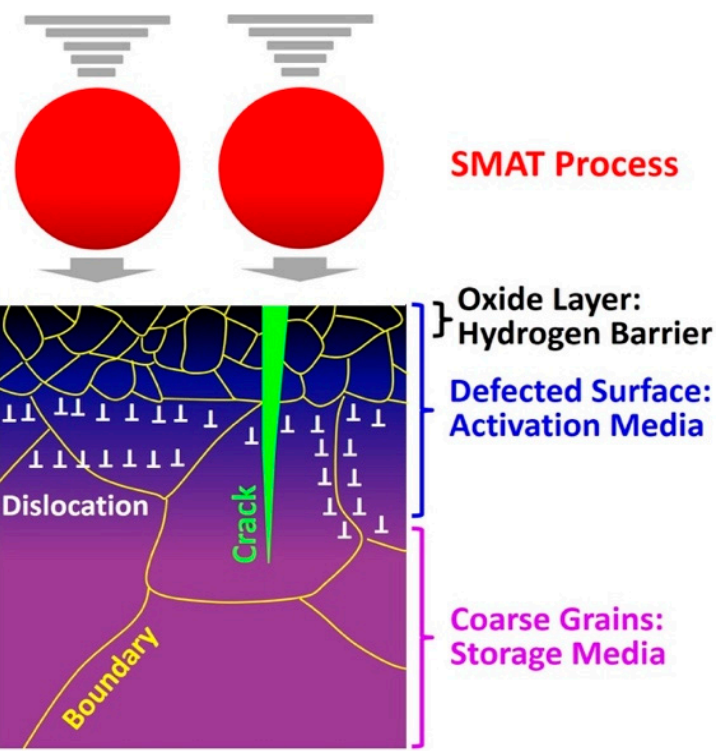

Figure 16. Mechanism of activation of Ti-V-Cr alloy with gradient structure after processing by SMAT [167] (reproduced with permission).

\section{Effect of Cold Rolling on Metal Hydrides}

In the usual configuration, cold rolling is performed by introducing a metal plate between rollers where it is compressed and squeezed, as shown in Figure 17. The term cold rolling (CR) is used when the temperature of the metal is below its recrystallization temperature. For temperature higher than the recrystallization temperature, the term Hot Rolling should be used. As the vast majority of the investigations involving metal hydrides have been using $\mathrm{CR}$, we restrict our discussion to this method. Cold rolling could be performed on the metal or on its hydride form. The problem with cold rolling a hydride is the brittle nature of most hydrides. Processing a powder in a horizontal milling machine is not convenient. A solution of this problem is to perform the milling vertically, as shown in Figure 17.

Sheets, foils

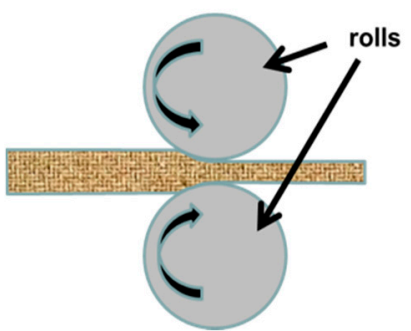

(a) powders

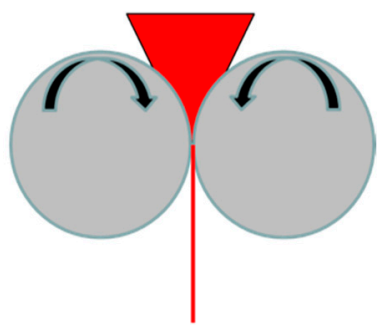

(b)

Figure 17. Schematic illustration of Cold Rolling (CR) configurations: (a) conventional; and (b) powder processing. Adapted from Ref. [199].

\subsection{Cold rolling on $\mathrm{Mg}$-Pd system}

The effects of CR on magnesium and its alloys have been extensively studied [157,200-227]. One reason is that magnesium has a high hydrogen storage capacity $(7.6 \mathrm{wt} \%)$. The other reason is that magnesium is ductile and could be processed easily by CR. However, as magnesium has a limited number of slip planes in its hexagonal crystal structure, it suffers an important work hardening upon repetitive CR $[228,229]$. Fortunately, for metal hydrides, this is usually not a problem because when 
hydrogenated the hydride will naturally turn into powder due to the large lattice expansion of the hydride phase.

The system Mg-Pd was the subject of some of the early studies on the effect of CR on magnesium alloys [201,202,206,207]. Because of the high price of palladium, this is not attractive for practical applications but, because palladium is a good catalyst and there are few intermetallics in the Mg-Pd phase diagrams, this system is a good candidate for fundamental investigation.

Dufour and Huot have investigated the addition of a small amount of Pd by cold rolling. They used Mg plates of $1 \mathrm{~mm}$ thickness that were stacked with Pd foil of thickness $0.025 \mathrm{~mm}$ to get a proportion of 2.5 at $\%$ Pd [201]. Cold rolling was performed in air, at room temperature on a laboratory-scale rolling apparatus. After each roll, the sample was folded in two and rolled again thus having a 50\% reduction of thickness at each rolling pass. Figure 18 shows the distribution of palladium in magnesium for samples rolled 20 times compared to the same composition milled $2 \mathrm{~h}$ on a SPEX8000 milling machine. The distribution of palladium is much coarser in the cold rolled sample compared to the ball milled one considering that the micrograph of the cold rolled sample is magnified 40 times while the magnification of the ball milled sample is $500 \times$.

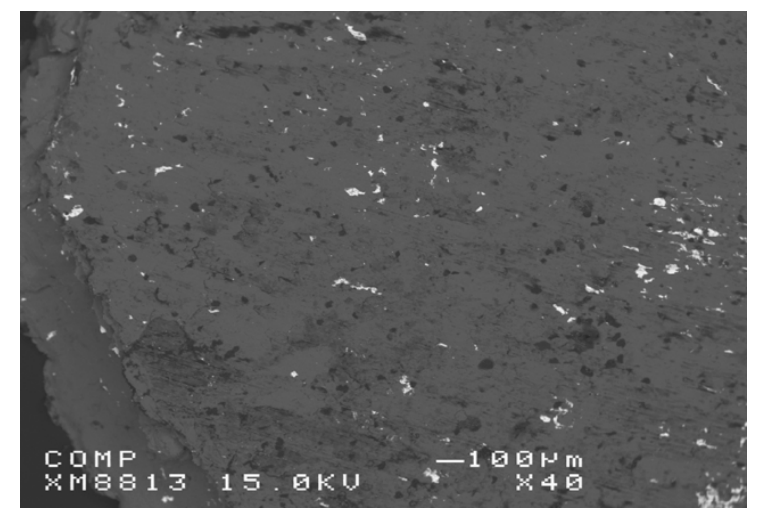

(a)

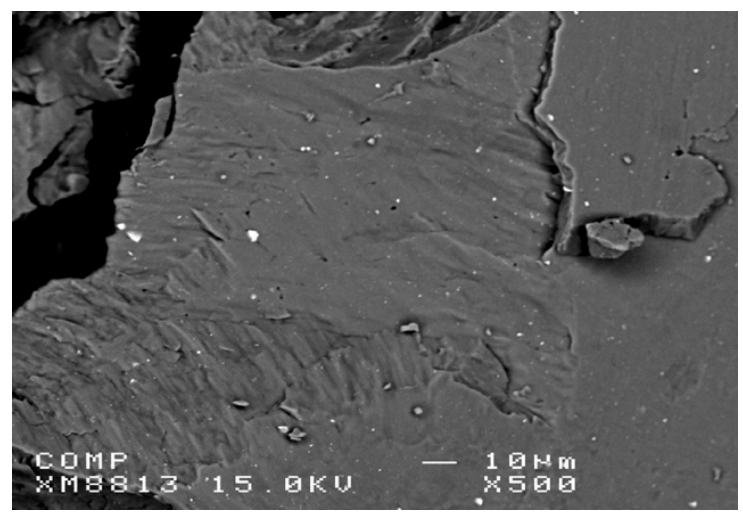

(b)

Figure 18. Backscattered electron micrographs of Mg-Pd 2.5 at \%: (a) after 20 rolling passes; and (b) after $2 \mathrm{~h}$ of ball milling. The white marks are palladium particles. Adapted from Ref. [201].

The X-ray diffraction pattern of the sample after cold rolling (20 passes) is shown in Figure 19. The sample is highly textured along (002) direction, which is expected for a hexagonal structure. The peaks are still relatively sharp, which indicates that the sample is not nanocrystalline. The palladium peaks are barely visible due to the low concentration of this element.

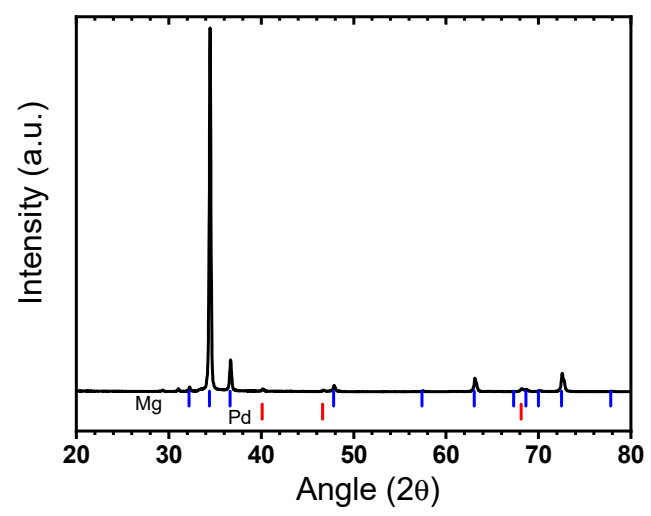

Figure 19. X-ray diffraction pattern of $\mathrm{Mg}-\mathrm{Pd} 2.5$ at $\%$ after 20 rolling passes. $\mathrm{Cu} \mathrm{k} \alpha$ radiation.

The first hydrogenation (activation) at $623 \mathrm{~K}$ and under a hydrogen pressure of $1.3 \mathrm{MPa}$ is presented in Figure 20. 


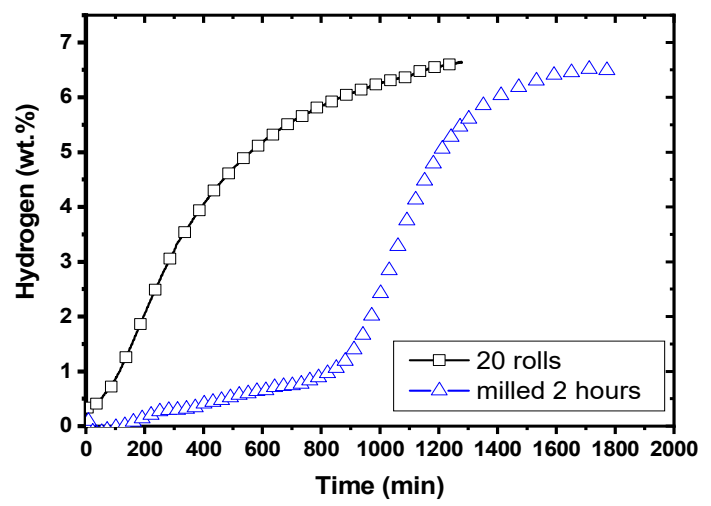

Figure 20. First hydrogenation at $623 \mathrm{~K}$ under 1.3 MPa of hydrogen of Mg-Pd 2.5 at $\%$ after 20 rolling passes and after $2 \mathrm{~h}$ of milling.

We see that the cold rolled sample has a much faster first hydrogenation compared to the ball milled one. The hydrogenation starts readily, without any incubation time as in the case of the ball milled sample. Figure 21 shows the backscatter micrographs of the cold rolled and ball milled samples after hydrogenation. In the case of cold rolled sample, the interdiffusion of magnesium and palladium results more important than for the ball milled sample. The cold rolled sample also seems to me more porous.

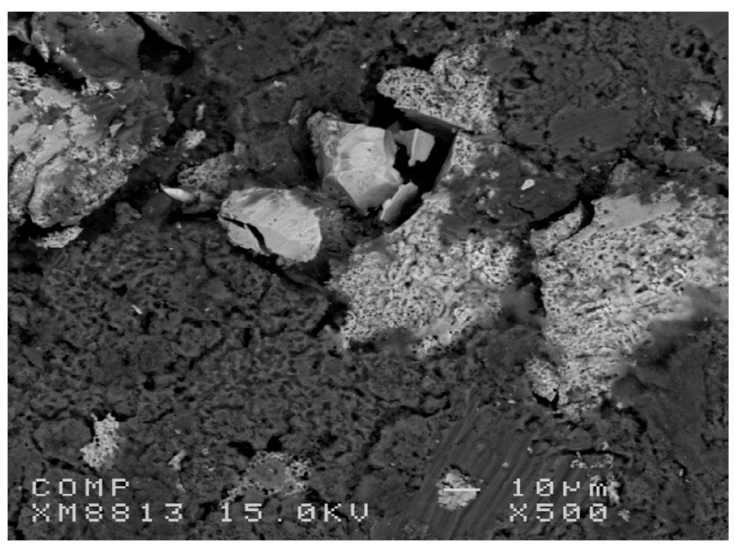

(a)

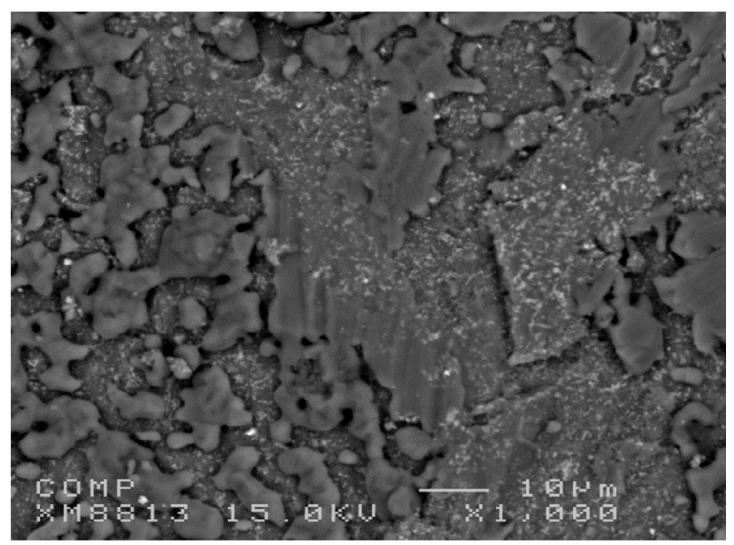

(b)

Figure 21. Backscattered electron micrographs of $\mathrm{Mg}-\mathrm{Pd} 2.5$ at $\%$ after first hydrogenation: (a) after 20 rolling passes; and (b) after $2 \mathrm{~h}$ of ball milling. The white areas are palladium-rich regions.

From these results, we conclude that even if the distribution of palladium is much finer in the ball-milled sample, the kinetic is not better than for the much coarser distribution of palladium. Therefore, particle size is not the only factor influencing the action of a catalyst. Cold rolling probably produces a much stronger connection between the magnesium matrix and the palladium particle. This facilitates the inter-diffusion of magnesium and palladium and produces a much faster kinetic.

\subsection{Cold rolling on $A B_{5}$ system}

Many metal hydrides are ordered stoichiometric compounds formed by a hydride forming element (A) and a non-hydride forming element (B). The resulting ternary hydride could be written as $A_{m} B_{n} H_{x}$ where $m$ and $n$ are integers and $x$ is a real number [230]. Amongst the many different $\mathrm{m}$ and $\mathrm{n}$ combinations, the system $\mathrm{AB}_{5}$ is one of the most studied. The classical example is $\mathrm{LaNi}_{5}$, which was reported in 1970 by van Vucht et al. [231]. The $\mathrm{AB}_{5}$ type metal hydrides are mainly used as hydride electrodes in Ni-MH batteries but they are also considered for hydrogen storage and purification [232-235]. One of the problems facing the $\mathrm{AB}_{5}$ type metal hydrides is the slow 
first hydrogenation. This is usually explained by a thin surface oxide, which prevents hydrogen diffusion to the bare metal. Recently, it has been shown that cold rolling could greatly enhance the first hydrogenation of $\mathrm{LaNi}_{5}$ [236] and $\mathrm{CaNi}_{5}$ [237]. From the literature, the maximum capacity of $\mathrm{CaNi}_{5}$ and $\mathrm{LaNi}_{5}$ are, respectively, $1.8 \mathrm{wt} \%$ [238] and $1.5 \mathrm{wt} \%$ [231].

The $\mathrm{LaNi}_{5}$ powder and the raw $\mathrm{CaNi}_{5}$ alloy $(99.5 \%$ pure) were both used in their as-received state. A Durston DRM 130 cold rolling apparatus was used but it was modified in order to be able to perform cold rolling vertically instead of horizontally. Details of the cold rolling and ball milling are given in Ref. [236].

Figure 22 shows the first hydrogenation of $\mathrm{CaNi}_{5}$ and $\mathrm{LaNi}_{5}$ in their as-received, cold rolled and ball milled states. Several features can be seen in this figure. First, the as-received powders have a long incubation time with a relatively slow kinetics afterwards. In the case of $\mathrm{LaNi}_{5}$, the total capacity is much less than the theoretical one even after waiting for almost 20,000 s (5.5 h). Second, the effect of cold rolling is to reduce the incubation time and increase the kinetic for both alloys but, for the $\mathrm{CaNi}_{5}$ alloy, the capacity is also greatly increased. Thirdly, ball milling produced a much faster kinetic and also the initial capacity was higher, both samples readily absorbing a small amount of hydrogen after only a few seconds. However, the $\mathrm{CaNi}_{5}$ alloy presented a reduction of capacity. In the assessment of both methods, one has to consider that cold rolling was done in air while ball milling was done under argon. This makes cold rolling much easier and faster to perform than ball milling. In addition, cold rolling could be processed in continuous mode while ball milling is a batch process. Therefore, for commercial applications, cold rolling is probably a better candidate for powder processing than ball milling.

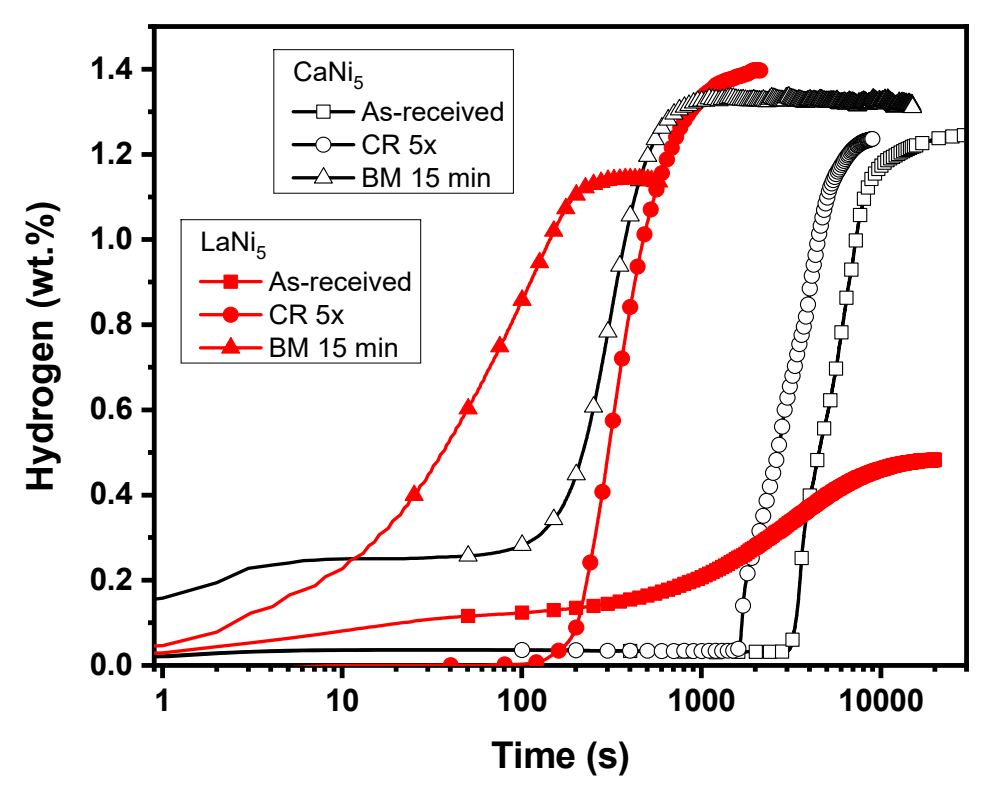

Figure 22. First hydrogenation at $323 \mathrm{~K}$ under $1.5 \mathrm{MPa}$ of hydrogen of $\mathrm{CaNi}_{5}$ and $\mathrm{LaNi}_{5}$ in their as-received, cold rolled and ball milled states. (Adapted from refs. [236,237]).

Even though the utilization of cold rolling for metal hydrides is relatively new, in addition to these two examples, many other systems have been investigated [214,217,225,227,239-243]. However, there is still a lack of understanding the exact reason for the effectiveness of cold rolling on the hydrogenation behavior of metal hydride. As cold rolling is a well-known industrial technique, it is worthwhile to continue fundamental research and studying scaling-up problems when this technique is applied to metal hydrides. 


\section{In Situ Characterization of the Mechanochemical Reaction}

In Section 4, we saw that pressure and temperature can be monitored in real time during milling (such as in GTM jars manufactured by Fritsch). These measurements can be seen as an in situ characterization of the process, as it allows to detect exothermic events or the steps of gas uptake or release. Such reaction profiles give the researchers an idea about the reaction profile and, in particular, when the milling process should be stopped in order to do an ex-situ characterization of the reaction products. This study of the reaction path is better guided than the blind search along the axis of the reaction time. However, the ex-situ characterization has a number of shortcomings. The first is a problem detecting short living intermediates. Therefore, the intermediate reaction steps in mechanochemical synthesis remain poorly understood by traditional ex-situ characterization of the reaction mixture.

\subsection{First In Situ Diffraction Studies}

A significant step forward in the in situ characterization of the reaction mixture has been made using a combination of mechano-chemical synthesis with synchrotron X-ray powder diffraction [244,245]. The high-energy $X$-ray beam was sent through thick walled $(3.1 \mathrm{~mm}$ each wall) plastic jars where a mechanochemical reaction was performed using a shaker mill. One or several stainless-steel balls can be used with little time (or even no time given some optimization) to get their trajectories onto the path of the X-ray beam. The use of high-intensity synchrotron beam allowed reaching time resolution of a few seconds. For example, this setup allowed detecting an intermediate in the mechanochemical synthesis of the metal-organic framework ZIF-8 having a new topology [246]. Already a year later, the first studies using this setup were done on the hydride systems [247]. This method allowed detecting even light hydrides containing weakly scattering elements and has shown a good time resolution. However, the following limits were identified:

- $\quad$ High energies (short wavelengths) are needed to penetrate the thick-walled plastic jars. This limits the use of the setup only to high-energy synchrotron beamlines with $\lambda$ or the order of $\sim 0.15 \AA$.

- The use of high-energy X-rays has another drawback: the powder diffraction data are squeezed in a short 20-range, with strongly overlapping Bragg peaks, making it difficult to collect high-resolution data.

- $\quad$ The thick-walled plastic jars produce high amorphous background, which needs to be subtracted for presentation purposes when plotting data for weakly scattering samples, such as hydrides.

- $\quad$ The plastic jars have to be machined in a workshop at relatively high price and they do not stand many milling cycles, being especially prone to degradation when using small amounts of solvents in liquid assisted grinding.

- The large sample volume gives rise to broad or even split diffraction peaks coming from the sample sticking on the opposite sides of the milling jar. In part, this problem can be solved by hitting the milling volume by X-ray beam close to the inner wall edge. Thus, the X-ray beam should not go through the middle of the milling jar but close to its edge. This also reduces the probability of hitting the metal balls with the X-ray beam.

Indeed, the diffraction on the milling balls add an extra complexity. This can be avoided by finding appropriate shaking frequencies allowing for stable trajectories of the milling balls. In this case, it is possible to probe the space where the milling balls. The sketch of the resulting set up and the illustration of the resolution function are shown in Figure 23.

This technique is becoming increasingly popular in different fields of mechanochemistry [248-252] and was applied to situ Raman spectroscopy [253] as well as in combined Raman/diffraction/ thermography studies [254]. 


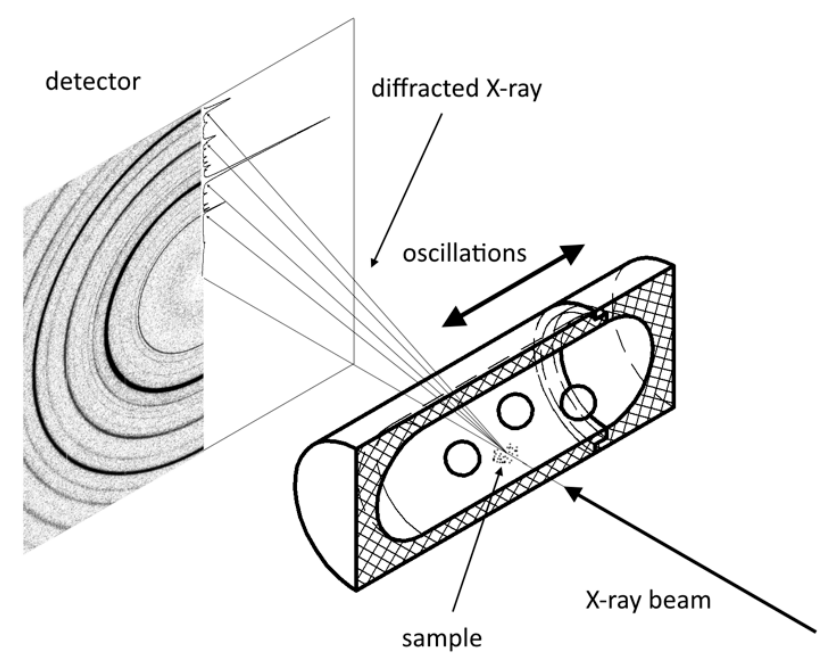

(a)

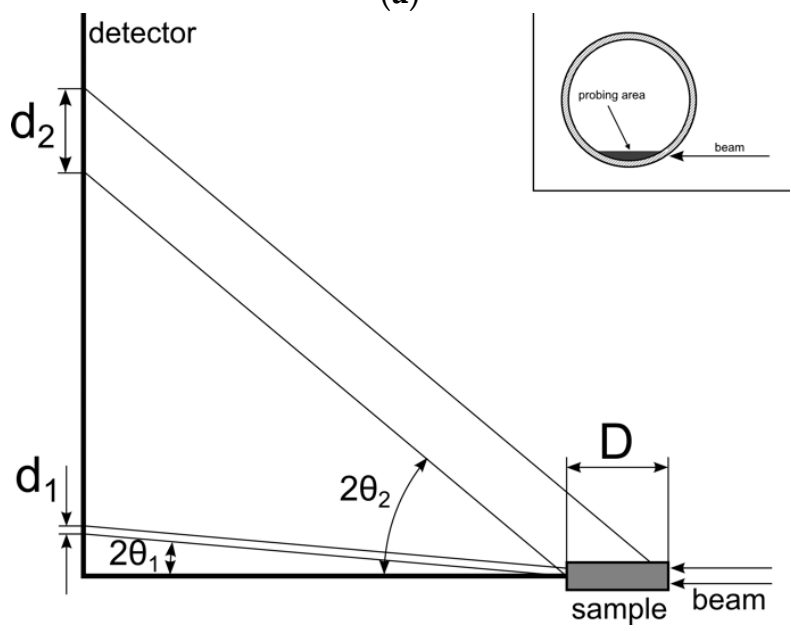

(b)

Figure 23. The scheme of in situ ball-milling experiment monitored by powder X-ray diffraction using a shaker mill (a). The X-ray beam goes through the bottom of the oscillating plastic jar containing the sample and metal balls. Diffracted X-rays are registered by a 2D detector. The jar is positioned so that the X-ray beam is hitting the sample on the inner wall (on the bottom). The resolution function: The width of the diffraction peaks dependd on the $2 \theta$ angle (b). D is the sample thickness; and $\mathrm{d}_{1}$ and $d_{2}$ are the projections of the sample on the detector at diffraction angles of $2 \theta_{1}$ and $2 \theta_{2}$, respectively. The Figures are taken from [255].

\subsection{Improving the Design of the Milling Jars by 3D Printing}

The drawbacks listed above were considered in building the next generation of the milling jars, which had an optimized shape and lower cost, all thanks to the 3D printing technologies becoming widely available in recent years. The 3D-printed polylactic acid (PLA) jars show good mechanical strength; they are also more resistant to solvents compared to polymethyl methacrylate (PMMA). There materials are robust enough to withstand the impacts from the grinding balls; they are amorphous and thus produce no diffraction peaks; and they are quite resistant to solvents allowing for liquid-assisted grinding (LAG).

Compared to the first-generation jars described above, a major idea of the improvement here was to reduce the wall thickness of the jar in order to decrease its contribution to the background. In addition, the sample thickness is reduced in order to keep good resolution at high angles. One way to do this is using a design of a jar with two separate chambers: one in which the actual ball-milling 
reaction occurs, and another in which the powder is characterized by X-ray diffraction. This and other designs are shown in Figure 24.

(a) Type 0 , basic
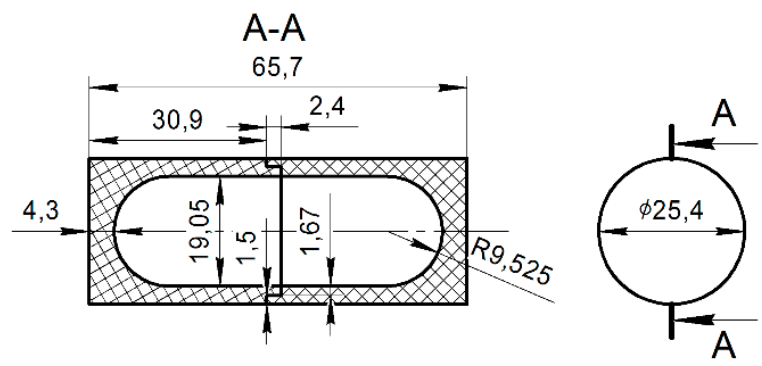

(b) Type 1, long body
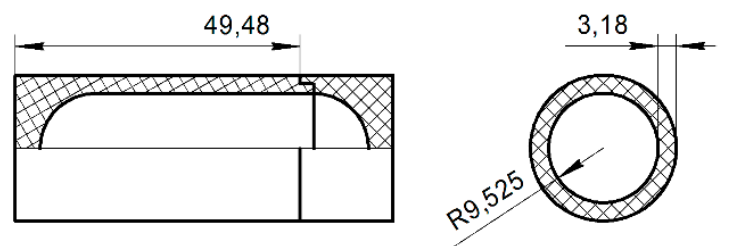

(c) Type 2, thin-walled
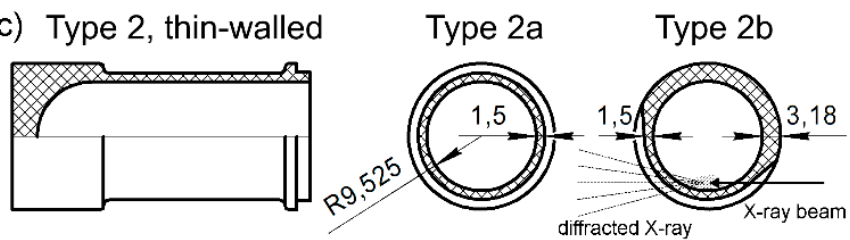

(d) Type 3, thin-walled with a groove

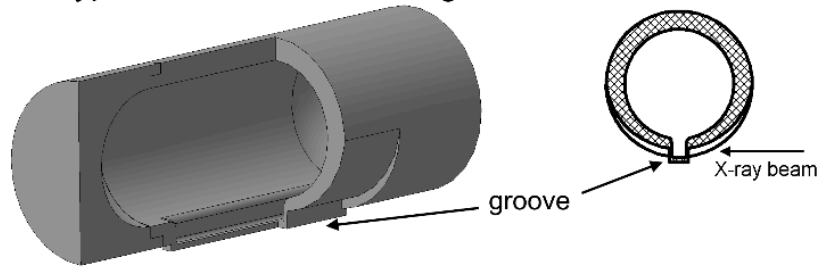

(e) Type 4, two-chamber
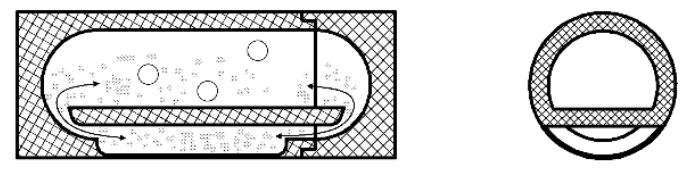

Figure 24. Designs of the 3D printed milling jars: (a) Type 0 jar, basic design from Ref. [1]; (b) Type 1 jar, with a joint point near the end of the jar; (c) Type 2 thin-walled jar; (d) Type 3 thin-walled jar with a groove; and (e) Type 4 two-chamber jar.

The modified wall thickness, the use of a thin-walled sampling groove and of a two-chamber design, where the milling and diffraction take place in two communicating volumes, allow for a reduced background/absorption and higher angular resolution, with a perspective for use at lower energy beamlines. Although all the tested jars showed good efficiency, the main drawback of the Type 3 and 4 jars is that they are not suitable for liquid-assisted grinding experiment. In practice, wet powders easily stick inside the narrow parts of the jars, thus the material exposed to X-rays is not taking part in the reaction. On the other hand, the Type 3 thin-walled jars with a groove is seen as the most promising for measurements at low energy beamlines aiming for relatively high angular resolution: the thin-walled groove contains the sample within a small volume, providing both for a low background/absorption and for higher resolution in the reciprocal space. Besides the improved 
resolution and the background, the big advantage of this approach is the ease of use and low cost: the source files for printing the jars are available as a supporting information in [255].

\subsection{Going for Ultimate Angular Resolution and an Efficient Sampling}

Further improvement was achieved using a relatively complicated reaction cell, shown in Figure 25. The innovative part is the grinding container, which follows the vertical grinding motion going up to $50 \mathrm{~Hz}$ provided by Pulverisette 23 from Fritsch. The vessel can also rotate continuously on its axis at a rate of $0.1-0.5 \mathrm{~Hz}$. Frequency of the milling and rotation speed of the jar are remotely controlled to synchronize the experiment outside the hutch. A lower energy X-ray beam of $\lambda \sim 0.7 \AA$ is typically used. In situ ball milling experiments were performed at the X04SA Materials Science (MS) beamline at the Swiss Light Source (SLS), Paul Scherrer Institute. During a typical in situ ball milling experiment, the X-ray beam passes through the probing windows while the jar is vigorously shaking and slowly spinning. Scattered X-rays were detected with a 1D multistrip detector Mythen II or a 2D hybrid pixel array detector Pilatus 6M. This setup is available there to MS beamline users since September 2016.

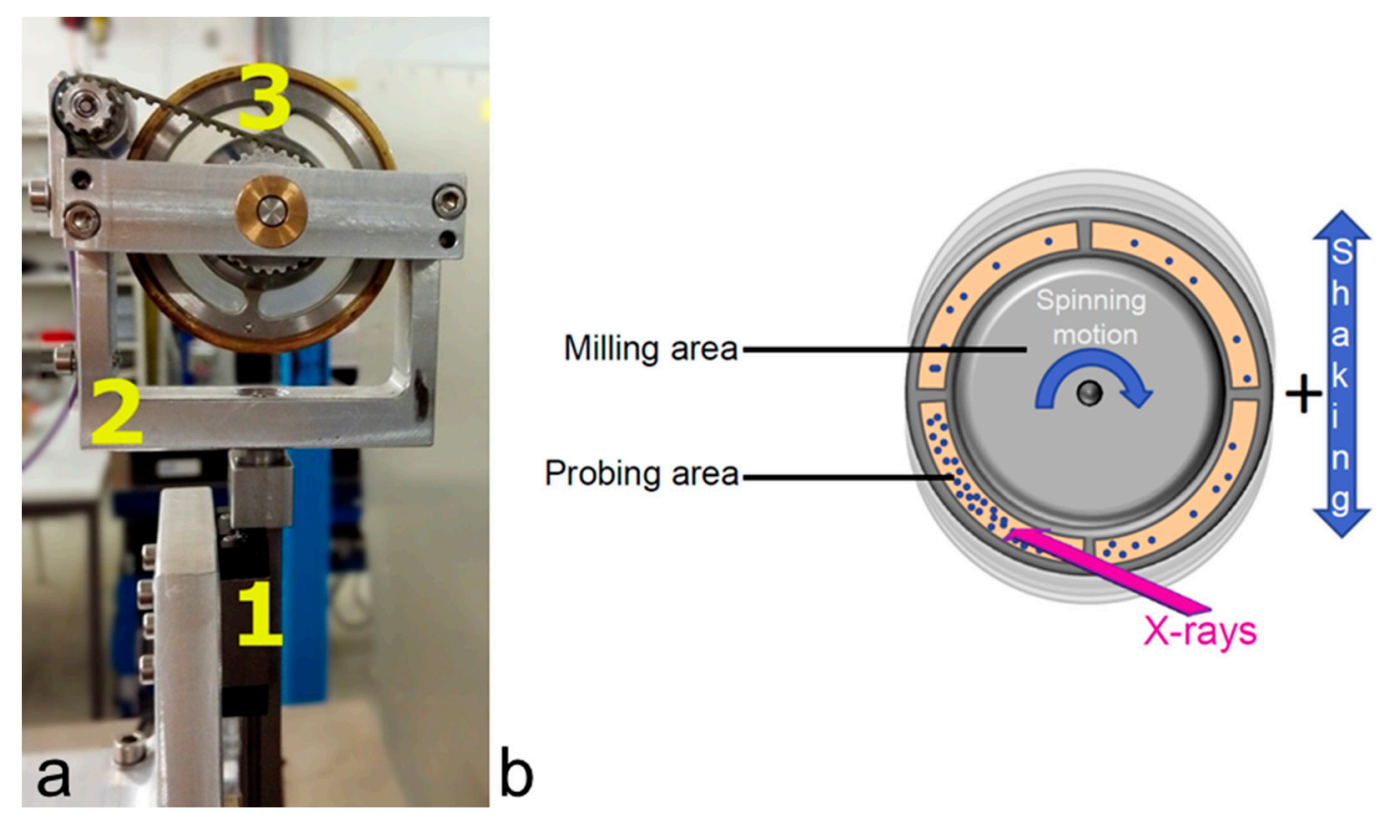

Figure 25. (a) Ball mill setup with the stroking device marked in 1, the frame holder in 2 and the jar container in 3; and (b) schematic of the jar container and motion principles [256].

The particular geometry of the grinding vessel results in PXRD data displaying significantly lower background and much sharper Bragg peaks, which in turn allow more sophisticated analysis of mechanochemical processes. Indeed, the FWHM of the standard $\mathrm{LaB}_{6}$ in this setup is about the same as in a $0.8 \mathrm{~mm}$ capillary. This main improvement in the peak width would not have been possible if X-rays were passing through the entire jar. The extra spinning motion of the milling jar is also a big improvement in the way of measuring the sample. With the previous setups $[244,245,255]$, powder could be trapped inside the probing area, biasing the true reaction advancement as the same part was probed over time. This cannot occur with the present prototype for neat grinding, although this may be still problematic in the case of liquid-assisted grinding. Moreover, with this recent design, it will likely be easier and more efficient to couple the in-situ diffraction with other analytical techniques.

With regard to the synthesis of hydrides, the clear advantage of the improved resolution is illustrated in Figure 26, showing the data collected at high energy beamline using the original setup as described in Refs. [244,245] and the most recent design described in Ref. [256]. 


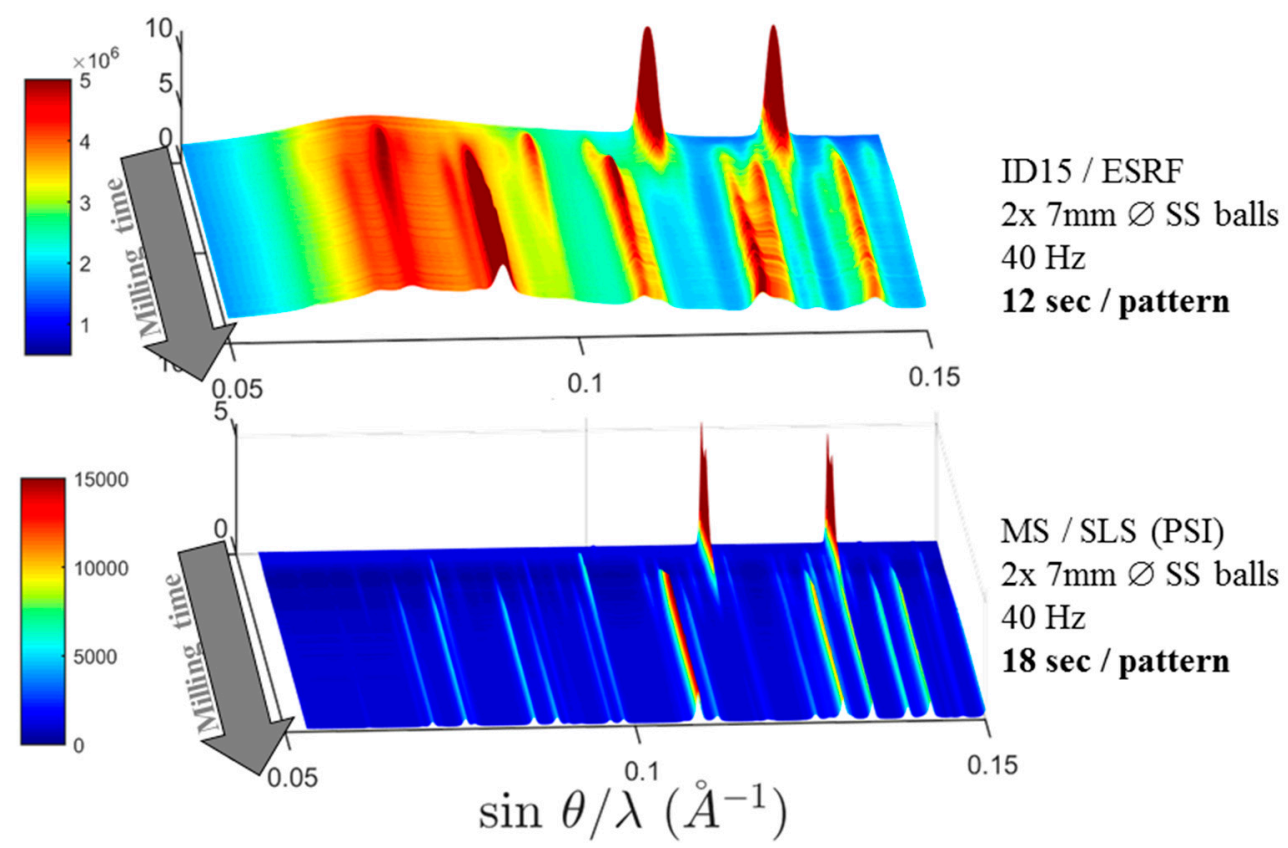

Figure 26. Comparison of XRD patterns collected during the mechanochemical reaction between $\mathrm{LiBH}_{4}$ and $\mathrm{CsBH}_{4}$, taken at high energy ESRF beamline (former ID15, $90 \mathrm{keV}$ ) and at medium energy MS beamline at SLS (16 keV) [256].

\section{Conclusions}

Mechanosynthesis is a powerful way to synthesize and modify hydrogen storage materials. In this paper, we show that through mechanosynthesis a wide range of complex hydrides can be synthesized. In fact, mechanosynthesis is sometimes the only way, or at least the most efficient way, to make these compounds. In addition, milling at low temperature (cryomilling) or under hydrogen pressure enables the synthesis of new materials in a relatively easy way. In recent years, new synthesis methods, collectively known as Severe Plastic Deformation (SPD) techniques, have been used to prepare metal hydrides. In this paper, we demonstrate the high efficiency of High-Pressure Torsion (HPT), Surface Mechanical Attrition Treatment (SMAT), and cold rolling to enhance the hydrogen storage properties of metal hydrides. Using these techniques, the effect of grain boundaries, dislocations, stacking faults, and amorphous phases can be studied. Fundamental understanding of the mechanochemistry process can now be better studied thanks to the new technique of in situ X-ray diffraction. These development of new synthesis and characterization techniques are proof that the field of mechanochemistry has a bright future and will continue to bring new and exciting discoveries.

Author Contributions: All authors contributed to the introduction and conclusion chapters. Chapter 2 was written by T.R.J. and M.H.; B.C.H. and S.D. wrote chapter 3; M.L. and F.C. were responsible for chapter 4. Chapter 5 was written by K.E., while T.G. was responsible for chapter 6 . J.H. wrote chapter 7 and chapter 8 was written by Y.F. Editorial review and supervision of the whole paper was performed by S.S. and J.H.

Funding: K.E. acknowledges the MEXT, Japan for a Grant-in-Aid for Scientific Research (B) (No. 16H04539). T.G. acknowledges the support by the French State Program "Investment in the future" operated by the National Research Agency (ANR), referenced by ANR-11-LABX-0008-01 (Labex DAMAS). J.H. acknowledges the funding from a NSERC discovery grant. M.H. acknowledges the funding from the project 05K16VK2 "Energy research with Neutrons (ErwiN)" by the German Federal Ministry of Education and Research (BMBF).

Acknowledgments: J.H. would like to thank M. Tousignant and J. Dufour for the cold rolling experimental part. S.S. acknowledges funding from the NANO2021 program of the Norwegian Research Council (project number 286298). Y.F. thanks FNRS for financial support.

Conflicts of Interest: The authors declare no conflict of interest manuscript, or in the decision to publish the results. The funders had no role in the design of the study; in the collection, analyses, or interpretation of data; in the writing of the manuscript, or in the decision to publish the results. 


\section{References}

1. Benjamin, J.S. Mechanical Alloying. Sci. Am. 1976, 235, 40. [CrossRef]

2. Benjamin, J.S.; Volin, T.E. The mechanism of mechanical alloying. Met. Mater. Trans. A 1974, 5, $1929-1934$. [CrossRef]

3. Suryanarayana, C. Mechanical alloying and milling. Prog. Mater. Sci. 2001, 46, 1-184. [CrossRef]

4. Richter, B.; Grinderslev, J.B.; Møller, K.T.; Paskevicius, M.; Jensen, T.R. From Metal Hydrides to Metal Borohydrides. Inorg. Chem. 2018, 57, 10768-10780. [CrossRef] [PubMed]

5. Huot, J.; Ravnsbæk, D.; Zhang, J.; Cuevas, F.; Latroche, M.; Jensen, T.R. Mechanochemical synthesis of hydrogen storage materials. Prog. Mater. Sci. 2013, 58, 30-75. [CrossRef]

6. Balema, V.P.; Wiench, J.W.; Pruski, M.; Pecharsky, V.K. Mechanically Induced Solid-State Generation of Phosphorus Ylides and the Solvent-Free Wittig Reaction. J. Am. Chem. Soc. 2002, 124, 6244-6245. [CrossRef] [PubMed]

7. Hagemann, H.; Cerny, R. Synthetic approaches to inorganic borohydrides. Dalton Trans. 2010, 39, 6006. [CrossRef]

8. Beyer, M.K.; Clausen-Schaumann, H. Mechanochemistry: The Mechanical Activation of Covalent Bonds. Chem. Rev. 2005, 105, 2921-2948. [CrossRef]

9. Bösenberg, U.; Doppiu, S.; Mosegaard, L.; Barkhordarian, G.; Eigen, N.; Borgschulte, A.; Jensen, T.R.; Cerenius, Y.; Gutfleisch, O.; Klassen, T.; et al. Hydrogen sorption properties of $\mathrm{MgH}_{2}-\mathrm{LiBH}_{4}$ composites. Acta Mater. 2007, 55, 3951-3958. [CrossRef]

10. Fichtner, M. Nanotechnological Aspects in Materials for Hydrogen Storage. Adv. Eng. Mater. 2005, 7, 443-455. [CrossRef]

11. Blanchard, D.; Brinks, H.W.; Hauback, B.C. Isothermal decomposition of LiAlD 4 . J. Alloys Compd. 2006, 416, 72-79. [CrossRef]

12. Callini, E.; Atakli, Z.Ö.K.; Hauback, B.C.; Orimo, S.-I.; Jensen, C.; Dornheim, M.; Grant, D.; Cho, Y.W.; Chen, P.; Hjörvarsson, B.; et al. Complex and liquid hydrides for energy storage. Appl. Phys. A 2016, 122, 1-22. [CrossRef]

13. Møller, K.T.; Jensen, T.R.; Akiba, E.; Li, H.-W. Hydrogen-A sustainable energy carrier. Prog. Nat. Sci. 2017, 27, 34-40. [CrossRef]

14. Møller, K.T.; Sheppard, D.; Ravnsbæk, D.B.; Buckley, C.E.; Etsuo, A.; Hai-Wen, L.; Jensen, T.R. Complex Metal Hydrides for Hydrogen. Thermal and Electrochemical Energy Storage. Energies 2017, 10, 1645. [CrossRef]

15. Callini, E.; Aguey-Zinsou, K.-F.; Ahuja, R.; Ares, J.R.; Bals, S.; Biliškov, N.; Chakraborty, S.; Charalambopoulou, G.; Chaudhary, A.-L.; Cuevas, F.; et al. Nanostructured materials for solid-state hydrogen storage: A review of the achievement of COST Action MP1103. Int. J. Hydrog. Energy 2016, 41, 14404-14428. [CrossRef]

16. Crivello, J.-C.; Dam, B.; Denys, R.V.; Dornheim, M.; Grant, D.M.; Huot, J.; Jensen, T.R.; De Jongh, P.; Latroche, M.; Milanese, C.; et al. Review of magnesium hydride-based materials: Development and optimisation. Appl. Phys. A 2016, 122, 97. [CrossRef]

17. Crivello, J.-C.; Denys, R.V.; Dornheim, M.; Felderhoff, M.; Grant, D.M.; Huot, J.; Jensen, T.R.; De Jongh, P.; Latroche, M.; Walker, G.S.; et al. Mg-based compounds for hydrogen and energy storage. Appl. Phys. A 2016, 122, 1-17. [CrossRef]

18. Yartys, V.A.; Lototskyy, M.V.; Akiba, E.; Albert, R.; Antonov, V.E.; Ares, J.R.; Baricco, M.; Bourgeois, N.; Buckley, C.E.; Bellosta von Colbe, J.M.; et al. Magnesium based materials for hydrogen based energy storage: Past, present and future. Int. J. Hydrog. Energy 2019, 44, 7809-7859. [CrossRef]

19. Milanese, C.; Jensen, T.; Hauback, B.; Pistidda, C.; Dornheim, M.; Yang, H.; Lombardo, L.; Zuettel, A.; Filinchuk, Y.; Ngene, P.; et al. Complex hydrides for energy storage. Int. J. Hydrog. Energy 2019, 44, 7860-7874. [CrossRef]

20. Von Colbe, J.B.; Ares, J.-R.; Barale, J.; Baricco, M.; Buckley, C.; Capurso, G.; Gallandat, N.; Grant, D.M.; Guzik, M.N.; Jacob, I.; et al. Application of hydrides in hydrogen storage and compression: Achievements, outlook and perspectives. Int. J. Hydrog. Energy 2019, 44, 7780-7808. [CrossRef]

21. Manickam, K.; Mistry, P.; Walker, G.; Grant, D.; Buckley, C.E.; Humphries, T.D.; Paskevicius, M.; Jensen, T.; Albert, R.; Peinecke, K.; et al. Future perspectives of thermal energy storage with metal hydrides. Int. J. Hydrog. Energy 2019, 44, 7738-7745. [CrossRef] 
22. Latroche, M.; Blanchard, D.; Cuevas, F.; El Kharbachi, A.; Hauback, B.C.; Jensen, T.R.; De Jongh, P.E.; Kim, S.; Nazer, N.S.; Ngene, P.; et al. Full-cell hydride-based solid-state Li batteries for energy storage. Int. J. Hydrog. Energy 2019, 44, 7875-7887. [CrossRef]

23. Fritsch, Product Information, Planetary Mills Classic Line. Available online: http://www.fritsch.de/uploads/ media/e_Planetary_Mills_classic_line.pdf (accessed on 11 March 2019).

24. Schilz, J. Internal Kinematics of Tumbler and Planetary Ball Mills: A Mathematical Model for the Parameter Setting. Mater. Trans. JIM 1998, 39, 1152-1157. [CrossRef]

25. Burgio, N.; Iasonna, A.; Magini, M.; Martelli, S.; Padella, F. Mechanical alloying of the Fe-Zr system. Correlation between input energy and end products. Il Nuovo Cim. D 1991, 13, 459-476. [CrossRef]

26. Murty, B.; Rao, M.M.; Ranganathan, S. Milling maps and amorphization during mechanical alloying. Acta Met. Mater. 1995, 43, 2443-2450. [CrossRef]

27. Orimo, S.-I.; Nakamori, Y.; Eliseo, J.R.; Zuettel, A.; Jensen, C.M.; Orimo, S. Complex Hydrides for Hydrogen Storage. Chemin 2007, 38, 4111-4132. [CrossRef]

28. Schlesinger, H.I.; Brown, H.C.; Finholt, A.E. The Preparation of Sodium Borohydride by the High Temperature Reaction of Sodium Hydride with Borate Esters1. J. Am. Chem. Soc. 1953, 75, 205-209. [CrossRef]

29. Černý, R.; Schouwink, P. The crystal chemistry of inorganic metal boro-hydrides and their relation to metal oxides. Acta Crystallogr. Sect. B Struct. Sci. Cryst. Eng. Mater. 2015, 71, 619-640. [CrossRef]

30. Paskevicius, M.; Jepsen, L.H.; Schouwink, P.; Černý, R.; Ravnsbæk, D.B.; Filinchuk, Y.; Dornheim, M.; Besenbacher, F.; Jensen, T.R. Metal borohydrides and derivatives-Synthesis, structure and properties. Chem. Soc. Rev. 2017, 46, 1565-1634. [CrossRef]

31. Frommen, C.; Sørby, M.H.; Heere, M.; Humphries, T.D.; Olsen, J.E.; Hauback, B.C. Rare Earth Borohydrides-Crystal Structures and Thermal Properties. Energies 2017, 10, 2115. [CrossRef]

32. Sato, T.; Miwa, K.; Nakamori, Y.; Ohoyama, K.; Li, H.-W.; Noritake, T.; Aoki, M.; Towata, S.-I.; Orimo, S.-I. Experimental and computational studies on solvent-free rare-earth metal borohydrides $\left(\mathrm{BH}_{4}\right)_{3}(\mathrm{R}=\mathrm{Y}, \mathrm{Dy}$, and Gd). Phys. Rev. B 2008, 77, 10. [CrossRef]

33. Olsen, J.E.; Frommen, C.; Sørby, M.; Hauback, B.C. Crystal structures and properties of solvent-free $\mathrm{LiYb}\left(\mathrm{BH}_{4}\right)_{4-\mathrm{x}} \mathrm{Cl}_{\mathrm{x}}, \mathrm{Yb}\left(\mathrm{BH}_{4}\right)_{3}$ and $\mathrm{Yb}\left(\mathrm{BH}_{4}\right)_{2-\mathrm{x}} \mathrm{Cl}_{\mathrm{x}}$. RSC Adv. 2013, 3, 10764. [CrossRef]

34. Frommen, C.; Sørby, M.; Ravindran, P.; Vajeeston, P.; Fjellvåg, H.; Hauback, B.; Sørby, M. Synthesis, Crystal Structure, and Thermal Properties of the First Mixed-Metal and Anion-Substituted Rare Earth Borohydride LiCe $\left(\mathrm{BH}_{4}\right)_{3}$ Cl. J. Phys. Chem. C 2011, 115, 23591-23602. [CrossRef]

35. Jaron, T.; Grochala, W. Y $\left(\mathrm{BH}_{4}\right)_{3}$-an old-new ternary hydrogen store aka learning from a multitude of failures. Dalton Trans. 2010, 39, 160-166. [CrossRef]

36. Frommen, C.; Aliouane, N.; Deledda, S.; Fonneløp, J.E.; Grove, H.; Lieutenant, K.; Llamas-Jansa, I.; Sartori, S.; Sørby, M.H.; Hauback, B.C. Crystal structure, polymorphism, and thermal properties of yttrium borohydride $\mathrm{Y}\left(\mathrm{BH}_{4}\right)_{3}$. J. Alloys Compd. 2010, 496, 710-716. [CrossRef]

37. Ravnsbæk, D.B.; Filinchuk, Y.; Černyý, R.; Ley, M.B.; Haase, D.; Jakobsen, H.J.; Skibsted, J.; Jensen, T.R. Thermal Polymorphism and Decomposition of $\mathrm{Y}\left(\mathrm{BH}_{4}\right)_{3}$. Inorg. Chem. 2010, 49, 3801-3809.

38. Ley, M.B.; Jepsen, L.H.; Lee, Y.-S.; Cho, Y.W.; Von Colbe, J.M.B.; Dornheim, M.; Rokni, M.; Jensen, J.O.; Sloth, M.; Filinchuk, Y.; et al. Complex hydrides for hydrogen storage-New perspectives. Mater. Today 2014, 17, 122-128. [CrossRef]

39. Yan, Y.; Li, H.-W.; Sato, T.; Umeda, N.; Miwa, K.; Towata, S.-I.; Orimo, S.-I. Dehydriding and rehydriding properties of yttrium borohydride $\mathrm{Y}\left(\mathrm{BH}_{4}\right)_{3}$ prepared by liquid-phase synthesis. Int. J. Hydrog. Energy 2009, 34, 5732-5736. [CrossRef]

40. Koźmiński, W.; Grochala, W.; Jaroń, T. Phase transition induced improvement in $\mathrm{H}_{2}$ desorption kinetics: The case of the high-temperature form of $\mathrm{Y}\left(\mathrm{BH}_{4}\right)_{3}$. Phys. Chem. Chem. Phys. 2011, 13, 8847.

41. Gennari, F.; Esquivel, M. Synthesis and dehydriding process of crystalline $\mathrm{Ce}\left(\mathrm{BH}_{4}\right)_{3}$. J. Alloys Compd. 2009, 485, L47-L51. [CrossRef]

42. Li, H.-W.; Yan, Y.; Orimo, S.-I.; Züttel, A.; Jensen, C.M. Recent Progress in Metal Borohydrides for Hydrogen Storage. Energies 2011, 4, 185-214. [CrossRef]

43. Zhang, B.J.; Liu, B.H.; Li, Z.P. Destabilization of $\mathrm{LiBH}_{4}$ by $(\mathrm{Ce}, \mathrm{La})(\mathrm{Cl}, \mathrm{F})_{3}$ for hydrogen storage. J. Alloys Compd. 2011, 509, 751-757. [CrossRef]

44. Ley, M.B.; Boulineau, S.; Janot, R.; Filinchuk, Y.; Jensen, T.R. New Li Ion Conductors and Solid State Hydrogen Storage Materials: $\mathrm{LiM}\left(\mathrm{BH}_{4}\right)_{3} \mathrm{Cl}, \mathrm{M}=\mathrm{La}, \mathrm{Gd}$. J. Phys. Chem. C 2012, 116, 21267-21276. [CrossRef] 
45. Skripov, A.V.; Soloninin, A.V.; Ley, M.B.; Jensen, T.R.; Filinchuk, Y. Nuclear Magnetic Resonance Studies of BH 4 Reorientations and Li Diffusion in LiLa $\left(\mathrm{BH}_{4}\right)_{3}$ Cl. J. Phys. Chem. C 2013, 117, 14965-14972. [CrossRef]

46. Gennari, F.; Albanesi, L.F.; Puszkiel, J.; Larochette, P.A. Reversible hydrogen storage from $6 \mathrm{LiBH}_{4}-\mathrm{MCl}_{3}(\mathrm{M}$ $=\mathrm{Ce}, \mathrm{Gd}$ ) composites by in-situ formation of $\mathrm{MH}_{2}$. Int. J. Hydrog. Energy 2011, 36, 563-570. [CrossRef]

47. Heere, M.; Gharibdoust, S.H.P.; Frommen, C.; Humphries, T.D.; Ley, M.B.; Sørby, M.H.; Jensen, T.R.; Hauback, B.C. The influence of $\mathrm{LiH}$ on the rehydrogenation behavior of halide free rare earth (RE) borohydrides (RE = Pr, Er). Phys. Chem. Chem. Phys. 2016, 18, 24387-24395. [CrossRef]

48. Schouwink, P.; Ley, M.B.; Jensen, T.R.; Černý, R. Borohydrides: From sheet to framework topologies. Dalton Trans. 2014, 43, 7726-7733. [CrossRef]

49. Grinderslev, J.B.; Møller, K.T.; Bremholm, M.; Jensen, T.R. Trends in Synthesis, Crystal Structure, and Thermal and Magnetic Properties of Rare-Earth Metal Borohydrides. Inorg. Chem. 2019, 58, 5503-5517. [CrossRef]

50. Lee, Y.-S.; Shim, J.-H.; Cho, Y.W. Polymorphism and Thermodynamics of $\mathrm{Y}\left(\mathrm{BH}_{4}\right)_{3}$ from First Principles. J. Phys. Chem. C 2010, 114, 12833-12837. [CrossRef]

51. Ravnsbaek, D.B.; Sørensen, L.H.; Filinchuk, Y.; Reed, D.; Book, D.; Jakobsen, H.J.; Besenbacher, F.; Skibsted, J.; Jensen, T.R.; Ravnsbæk, D.B. Mixed-Anion and Mixed-Cation Borohydride $\mathrm{KZn}\left(\mathrm{BH}_{4}\right) \mathrm{Cl}_{2}$ : Synthesis, Structure and Thermal Decomposition. Eur. J. Inorg. Chem. 2010, 2010, 1608-1612. [CrossRef]

52. Ley, M.B.; Ravnsbæk, D.B.; Filinchuk, Y.; Janot, R.; Cho, Y.W.; Lee, Y.-S.; Skibsted, J.; Jensen, T.R. LiCe $\left(\mathrm{BH}_{4}\right)_{3} \mathrm{Cl}_{\text {, }}$ a New Lithium-Ion Conductor and Hydrogen Storage Material with Isolated Tetranuclear Anionic Clusters. Chem. Mater. 2012, 24, 1654-1663. [CrossRef]

53. Frommen, C.; Heere, M.; Riktor, M.D.; Sørby, M.H.; Hauback, B.C. Hydrogen storage properties of rare earth (RE) borohydrides $(\mathrm{RE}=\mathrm{La}, \mathrm{Er})$ in composite mixtures with $\mathrm{LiBH}_{4}$ and $\mathrm{LiH}$. J. Alloys Compd. 2015, 645, S155-S159. [CrossRef]

54. Ravnsbaek, D.; Filinchuk, Y.; Cerenius, Y.; Jakobsen, H.J.; Besenbacher, F.; Skibsted, J.; Jensen, T.R. A Series of Mixed-Metal Borohydrides. Angew. Chem. Int. Ed. 2009, 48, 6659-6663. [CrossRef] [PubMed]

55. Cerný, R.; Chul Kim, K.; Penin, N.; Da'nna, V.; Hagemann, H.; Sholl, D.S. AZn ${ }_{2}\left(B_{4}\right)_{5}(A=L i, N a)$ and $\mathrm{NaZn}\left(\mathrm{BH}_{4}\right)_{3}$ : Structural studies. J. Phys. Chem. C 2010, 114, 19127-19133. [CrossRef]

56. Solinas, I.; Lutz, H.D. Nonceramic preparation techniques for ternary halides $\mathrm{AB}_{2 \times 4}$ with $\mathrm{A}=\mathrm{Mg}, \mathrm{Mn}, \mathrm{Zn} \mathrm{B}$ $=\mathrm{Li}, \mathrm{Na} \mathrm{X}=\mathrm{Cl}$, Br-1. J. Solid State Chem. 1995, 117, 34-38. [CrossRef]

57. Černý, R.; Severa, G.; Ravnsbæk, D.B.; Filinchuk, Y.; D'Anna, V.; Hagemann, H.; Haase, D.; Jensen, C.M.; Jensen, T.R. $\mathrm{NaSc}\left(\mathrm{BH}_{4}\right)_{4}$ : A novel scandium-based borohydride. J. Phys. Chem. C 2010, 114, 1357-1364. [CrossRef]

58. Černyý, R.; Ravnsbæk, D.B.; Severa, G.; Filinchuk, Y.; Anna, V.D.; Hagemann, H.; Haase, D.; Skibsted, J.; Jensen, C.M.; Jensen, T.R. Structure and Characterization of $\mathrm{KSc}\left(\mathrm{BH}_{4}\right)_{4}$. J. Phys. Chem. C 2010, 114, 19540-19549. [CrossRef]

59. Li, Z.; Morigazaki, N.; Liu, B.; Suda, S. Preparation of sodium borohydride by the reaction of $\mathrm{MgH}_{2} \mathrm{with}$ dehydrated borax through ball milling at room temperature. J. Alloys Compd. 2003, 349, 232-236. [CrossRef]

60. Li, Z.P.; Liu, B.H.; Morigazaki, N.; Suda, S. Preparation of potassium borohydride by a mechanico-chemical reaction of saline hydrides with dehydrated borate through ball milling. J. Alloys Compd. 2003, 354, 243-247. [CrossRef]

61. Ravnsbæk, D.B.; Nickels, E.A.; Cerny, R.; Olesen, C.H.; David, W.I.F.; Edwards, P.P.; Filinchuk, Y.; Jensen, T.R. Novel Alkali Earth Borohydride $\mathrm{Sr}\left(\mathrm{BH}_{4}\right)_{2}$ and Borohydride-Chloride $\mathrm{Sr}\left(\mathrm{BH}_{4}\right) \mathrm{Cl}$. Inorg. Chem. 2013, 52, 10877-10885. [CrossRef]

62. Hagemann, H.; Longhini, M.; Kaminski, J.W.; Wesolowski, T.A.; Černyý, R.; Penin, N.; Sørby, M.H.; Hauback, B.C.; Severa, G.; Jensen, C.M. LiSc $\left(\mathrm{BH}_{4}\right)_{4}$ : A Novel Salt of Li+ and Discrete $\mathrm{Sc}\left(\mathrm{BH}_{4}\right)_{4}-\mathrm{Complex}$ Anions. J. Phys. Chem. A 2008, 112, 7551-7555. [CrossRef] [PubMed]

63. Hwang, S.-J.; Bowman, R.C.; Reiter, J.W.; Rijssenbeek, J.; Soloveichik, G.L.; Zhao, J.-C.; Kabbour, H.; Ahn, C.C.; Rijssenbeek, J. NMR Confirmation for Formation of $\left[\mathrm{B}_{12} \mathrm{H}_{12}\right]^{2-}$ Complexes during Hydrogen Desorption from Metal Borohydrides. J. Phys. Chem. C 2008, 112, 3164-3169. [CrossRef]

64. Kim, C.; Hwang, S.-J.; Bowman, R.C.; Reiter, J.W.; Zan, J.A.; Kulleck, J.G.; Kabbour, H.; Majzoub, E.H.; Ozolins, V. LiSc $\left(\mathrm{BH}_{4}\right)_{4}$ as a Hydrogen Storage Material: Multinuclear High-Resolution Solid-State NMR and First-Principles Density Functional Theory Studies. J. Phys. Chem. C 2009, 113, 9956-9968. [CrossRef] 
65. Ravnsbæk, D.B.; Ley, M.B.; Lee, Y.-S.; Hagemann, H.; D'Anna, V.; Cho, Y.W.; Filinchuk, Y.; Jensen, T.R. A mixed-cation mixed-anion borohydride $\mathrm{NaY}\left(\mathrm{BH}_{4}\right)_{2} \mathrm{Cl}_{2}$. Int. J. Hydrog. Energy 2012, 37, 8428-8438. [CrossRef]

66. Cerny, R.; Penin, N.; D'Anna, V.; Hagemann, H.; Durand, E.; Růžička, J. MgxMn(1-x) $\left(\mathrm{BH}_{4}\right)_{2}(\mathrm{x}=0-0.8)$, a cation solid solution in a bimetallic borohydride. Acta Mater. 2011, 59, 5171-5180. [CrossRef]

67. Ravnsbaek, D.B.; Sørensen, L.H.; Filinchuk, Y.; Besenbacher, F.; Jensen, T.R.; Ravnsbæk, D.B. Screening of Metal Borohydrides by Mechanochemistry and Diffraction. Angew. Chem. 2012, 124, 3582-3586. [CrossRef]

68. Lindemann, I.; Ferrer, R.D.; Dunsch, L.; Filinchuk, Y.; Černý, R.; Hagemann, H.; D'Anna, V.; Daku, L.M.L.; Schultz, L.; Gutfleisch, O. $\mathrm{Al}_{3} \mathrm{Li}_{4}\left(\mathrm{BH}_{4}\right)_{13}$ : A Complex Double-Cation Borohydride with a New Structure. Chem. A Eur. J. 2010, 16, 8707-8712. [CrossRef] [PubMed]

69. Mosegaard, L.; Møller, B.; Jørgensen, J.-E.; Filinchuk, Y.; Cerenius, Y.; Hanson, J.C.; DiMasi, E.; Besenbacher, F.; Jensen, T.R. Reactivity of $\mathrm{LiBH}_{4}$ : In Situ Synchrotron Radiation Powder X-ray Diffraction Study. J. Phys. Chem. C 2008, 112, 1299-1303. [CrossRef]

70. Arnbjerg, L.M.; Ravnsbæk, D.B.; Filinchuk, Y.; Vang, R.T.; Cerenius, Y.; Besenbacher, F.; Jørgensen, J.-E.; Jakobsen, H.J.; Jensen, T.R. Structure and Dynamics for $\mathrm{LiBH}_{4}-\mathrm{LiCl}$ Solid Solutions. Chem. Mater. 2009, 21, 5772-5782. [CrossRef]

71. Rude, L.; Zavorotynska, O.; Arnbjerg, L.; Ravnsbæk, D.B.; Malmkjær, R.; Grove, H.; Hauback, B.; Baricco, M.; Filinchuk, Y.; Besenbacher, F.; et al. Bromide substitution in lithium borohydride, $\mathrm{LiBH}_{4}-\mathrm{LiBr}$. Int. J. Hydrog. Energy 2011, 36, 15664-15672. [CrossRef]

72. Rude, L.H.; Groppo, E.; Arnbjerg, L.M.; Ravnsbæk, D.B.; Malmkjær, R.A.; Filinchuk, Y.; Baricco, M.; Besenbacher, F.; Jensen, T.R. Iodide substitution in lithium borohydride, $\mathrm{LiBH}_{4}-\mathrm{LiI}$. J. Alloys Compd. 2011, 509, 8299-8305. [CrossRef]

73. Liu, Y.; Reed, D.; Paterakis, C.; Vasquez, L.C.; Baricco, M.; Book, D. Study of the decomposition of a 0.62 $\mathrm{LiBH}_{4}-0.38 \mathrm{NaBH}_{4}$ mixture. Int. J. Hydrog. Energy 2017, 42, 22480-22488. [CrossRef]

74. Liu, Y.; Heere, M.; Vasquez, L.C.; Paterakis, C.; Sørby, M.H.; Hauback, B.C.; Book, D. Dehydrogenation and rehydrogenation of a $0.62 \mathrm{LiBH}_{4}-0.38 \mathrm{NaBH}_{4}$ mixture with nano-sized Ni. Int. J. Hydrog. Energy 2018, 43, 16782-16792. [CrossRef]

75. Ravnsbæk, D.B.; Rude, L.H.; Jensen, T.R. Chloride substitution in sodium borohydride. J. Solid State Chem. 2011, 184, 1858-1866. [CrossRef]

76. Rude, L.H.; Filinchuk, Y.; Sørby, M.H.; Hauback, B.C.; Besenbacher, F.; Jensen, T.R. Anion Substitution in $\mathrm{Ca}\left(\mathrm{BH}_{4}\right)_{2}-\mathrm{CaI}_{2}$ : Synthesis, Structure and Stability of Three New Compounds. J. Phys. Chem. C 2011, 115, 7768-7777. [CrossRef]

77. GharibDoust, S.; Brighi, M.; Sadikin, Y.; Ravnsbæk, D.B.; Černý, R.; Jensen, T.; Skibsted, J. Synthesis, Structure and $\mathrm{Li}$ Ion Conductivity of $\mathrm{LiLa}\left(\mathrm{BH}_{4}\right)_{3} \mathrm{X}, \mathrm{X}=\mathrm{Cl}, \mathrm{Br}$, I. J. Phys. Chem. C 2017, 121, 19010-19021. [CrossRef]

78. Gharibdoust, S.P.; Ravnsbæk, D.B.; Černý, R.; Jensen, T.R. Synthesis, structure and properties of bimetallic sodium rare-earth (RE) borohydrides, $\mathrm{NaRE}\left(\mathrm{BH}_{4}\right)_{4}, \mathrm{RE}=\mathrm{Ce}$, Pr, Er or Gd. Dalton Trans. 2017, 46, 13421-13431. [CrossRef]

79. Paterakis, C.; Guo, S.; Heere, M.; Liu, Y.; Contreras, L.F.; Sørby, M.H.; Hauback, B.C.; Reed, D.; Book, D. Study of the $\mathrm{NaBH}_{4}-\mathrm{NaBr}$ system and the behaviour of its low temperature phase transition. Int. J. Hydrog. Energy 2017, 42, 22538-22543. [CrossRef]

80. Heere, M.; Gharibdoust, S.P.; Sørby, M.H.; Frommen, C.; Jensen, T.R.; Hauback, B.C. In situ investigations of bimetallic potassium erbium borohydride. Int. J. Hydrog. Energy 2017, 42, 22468-22474. [CrossRef]

81. Reilly, J.J.; Wiswall, R.H. The reaction of hydrogen with alloys of magnesium and copper. Inorg. Chem. 1967, 6, 2220. [CrossRef]

82. Vajo, J.J.; Skeith, S.L.; Mertens, F. Reversible Storage of Hydrogen in Destabilized LiBH 4 . J. Phys. Chem. $B$ 2005, 109, 3719-3722. [CrossRef] [PubMed]

83. Vajo, J.J.; Mertens, F.; Ahn, C.C.; Bowman, R.C.J.; Fultz, B. Altering Hydrogen Storage Properties by Hydride Destabilization Through Alloy Formation: $\mathrm{LiH}$ and $\mathrm{MgH}_{2}$ Destabilized with Si. Chemin 2004, 35, 13977-13983. [CrossRef]

84. Barkhordarian, G.; Klassen, T.; Dornheim, M.; Bormann, R. Unexpected kinetic effect of MgB2 in reactive hydride composites containing complex borohydrides. J. Alloys Compd. 2007, 440, L18-L21. [CrossRef]

85. Barkhordarian, G.; Klassen, T.; Bormann, R. Fast hydrogen sorption kinetics of nanocrystalline $\mathrm{Mg}$ using $\mathrm{Nb}_{2} \mathrm{O}_{5}$ as catalyst. Scr. Mater. 2003, 49, 213-217. [CrossRef] 
86. Barkhordarian, G.; Klassen, T.; Bormann, R. Composite Material Storing Hydrogen, and Device for the Reversible Storage of Hydrogen. International Patent Application WO2006063627, 22 June 2006.

87. Dornheim, M.; Doppiu, S.; Barkhordarian, G.; Boesenberg, U.; Klassen, T.; Gutfleisch, O.; Bormann, R. Hydrogen storage in magnesium-based hydrides and hydride composites. Scr. Mater. 2007, 56, 841-846. [CrossRef]

88. Garroni, S.; Pistidda, C.; Brunelli, M.; Vaughan, G.B.M.; Surinach, S.; Baro, M.D. Hydrogen desorption mechanism of $2 \mathrm{NaBH}_{4}+\mathrm{MgH}_{2}$ composite prepared by high-energy ball milling. Scr. Mater. 2009, 60, 1129-1132. [CrossRef]

89. Mao, J.; Yu, X.; Guo, Z.; Liu, H.K.; Wu, Z.; Ni, J. Enhanced hydrogen storage performances of $\mathrm{NaBH}_{4}-\mathrm{MgH}_{2}$ system. J. Alloys Compd. 2009, 479, 619-623. [CrossRef]

90. Pistidda, C.; Napolitano, E.; Pottmaier, D.; Dornheim, M.; Klassen, T.; Baricco, M.; Enzo, S. Structural study of a new B-rich phase obtained by partial hydrogenation of $2 \mathrm{NaH}+\mathrm{MgB}_{2}$. Int. J. Hydrog. Energy 2013, 38, 10479-10484. [CrossRef]

91. Pistidda, C.; Garroni, S.; Minella, C.B.; Dolci, F.; Jensen, T.R.; Nolis, P.; Bösenberg, U.; Cerenius, Y.; Lohstroh, W.; Fichtner, M.; et al. Pressure Effect on the $2 \mathrm{NaH}+\mathrm{MgB}_{2}$ Hydrogen Absorption Reaction. J. Phys. Chem. C 2010, 114, 21816-21823. [CrossRef]

92. Heere, M.; Sørby, M.H.; Pistidda, C.; Dornheim, M.; Hauback, B.C. Milling time effect of Reactive Hydride Composites of $\mathrm{NaF} \mathrm{NaH} \mathrm{MgB} 2$ investigated by in situ powder diffraction. Int. J. Hydrog. Energy 2016, 41, 13101-13108. [CrossRef]

93. Kim, J.W.; Shim, J.-H.; Ahn, J.-P.; Cho, Y.W.; Kim, J.-H.; Oh, K.H. Mechanochemical synthesis and characterization of $\mathrm{TiB}_{2}$ and $\mathrm{VB}_{2}$ nanopowders. Mater. Lett. 2008, 62, 2461-2464. [CrossRef]

94. Olsen, J.E.; Sørby, M.H.; Hauback, B.C. Chloride-substitution in sodium borohydride. J. Alloys Compd. 2011, 509, L228-L231. [CrossRef]

95. Llamas-Jansa, I.; Aliouane, N.; Deledda, S.; Fonneløp, J.E.; Frommen, C.; Humphries, T.; Lieutenant, K.; Sartori, S.; Sørby, M.H.; Hauback, B.C. Chloride substitution induced by mechano-chemical reactions between $\mathrm{NaBH}_{4}$ and transition metal chlorides. J. Alloys Compd. 2012, 530, 186-192. [CrossRef]

96. Nakamori, Y.; Li, H.; Miwa, K.; Towata, S.-I.; Orimo, S.-I. Syntheses and Hydrogen Desorption Properties of Metal-Borohydrides $\mathrm{M}\left(\mathrm{BH}_{4}\right) \mathrm{n}(\mathrm{M}=\mathrm{Mg}$, $\mathrm{Sc}, \mathrm{Zr}$, Ti, and $\mathrm{Zn} ; \mathrm{n}=2-4)$ as Advanced Hydrogen Storage Materials. Mater. Trans. 2006, 47, 1898-1901. [CrossRef]

97. Nakamori, Y.; Li, H.-W.; Kikuchi, K.; Aoki, M.; Miwa, K.; Towata, S.; Orimo, S.-I. Thermodynamical stabilities of metal-borohydrides. J. Alloys Compd. 2007, 446, 296-300. [CrossRef]

98. Yang, C.-H.; Tsai, W.-T.; Chang, J.-K. Hydrogen desorption behavior of vanadium borohydride synthesized by modified mechano-chemical process. Int. J. Hydrog. Energy 2011, 36, 4993-4999. [CrossRef]

99. Llamas-Jansa, I.; Aliouane, N.; Deledda, S.; Fonneløp, J.E.; Frommen, C.; Lieutenant, K.; Sartori, S.; Sørby, M.H.; Hauback, B.C. Mechano-chemical reactions in $\mathrm{LiBH}_{4}+\mathrm{VCln}(\mathrm{n}=2$ and 3) mixtures. J. Alloys Compd. 2011, 509, S684-S687. [CrossRef]

100. Korablov, D.; Ravnsbæk, D.B.; Ban, V.; Filinchuk, Y.; Besenbacher, F.; Jensen, T.R. Investigation of $\mathrm{MBH}_{4}-\mathrm{VCl}_{2}$, $\mathrm{M}=\mathrm{Li}, \mathrm{Na}$ or K. Int. J. Hydrog. Energy 2013, 38, 8376-8383. [CrossRef]

101. Jeon, E.; Cho, Y. Mechanochemical synthesis and thermal decomposition of zinc borohydride. J. Alloys Compd. 2006, 422, 273-275. [CrossRef]

102. James, B.; Wallbridge, M. Metal tetrahydroborates. Prog. Inorg. Chem. 1970, 11, 99-231.

103. Ley, M.B.; Paskevicius, M.; Schouwink, P.; Richter, B.; Sheppard, D.A.; Buckley, C.; Jensen, T.R. Novel solvates $\mathrm{M}\left(\mathrm{BH}_{4}\right)_{3} \mathrm{~S}\left(\mathrm{CH}_{3}\right)_{2}$ and properties of halide-free $\mathrm{M}\left(\mathrm{BH}_{4}\right)_{3}(\mathrm{M}=\mathrm{Y}$ or $\mathrm{Gd})$. Dalton Trans. 2014, 43, 13333-13342. [CrossRef] [PubMed]

104. Ley, M.B.; Frommen, C.; Munroe, K.T.; Hauback, B.C.; Humphries, T.D.; Jensen, T.R. Crystal structure and in situ decomposition of $\mathrm{Eu}\left(\mathrm{BH}_{4}\right)_{2}$ and $\mathrm{Sm}\left(\mathrm{BH}_{4}\right)_{2}$. J. Mater. Chem. A 2015, 3, 691-698.

105. Visseaux, M.; Bonnet, F. Borohydride complexes of rare earths, and their applications in various organic transformations. Coord. Chem. Rev. 2011, 255, 374-420. [CrossRef]

106. Ley, M.B.; Jørgensen, M.; Černý, R.; Filinchuk, Y.; Jensen, T.R. From $\mathrm{M}\left(\mathrm{BH}_{4}\right)_{3}(\mathrm{M}=\mathrm{La}, \mathrm{Ce})$ Borohydride Frameworks to Controllable Synthesis of Porous Hydrides and Ion Conductors. Inorg. Chem. 2016, 55, 9748-9756. [CrossRef] [PubMed] 
107. Olsen, J.E.; Frommen, C.; Jensen, T.R.; Riktor, M.D.; Sørby, M.H.; Hauback, B.C. Structure and thermal properties of composites with RE-borohydrides ( $\mathrm{RE}=\mathrm{La}, \mathrm{Ce}, \mathrm{Pr}, \mathrm{Nd}, \mathrm{Sm}, \mathrm{Eu}, \mathrm{Gd}, \mathrm{Tb}, \mathrm{Er}, \mathrm{Yb}$ or $\mathrm{Lu}$ ) and $\mathrm{LiBH}_{4}$. RSC Adv. 2014, 4, 1570-1582. [CrossRef]

108. Gharibdoust, S.P.; Heere, M.; Sørby, M.H.; Ley, M.B.; Ravnsbæk, D.B.; Hauback, B.C.; Černý, R.; Jensen, T.R. Synthesis, structure and properties of new bimetallic sodium and potassium lanthanum borohydrides. Dalton Trans. 2016, 45, 19002-19011. [CrossRef] [PubMed]

109. Gharibdoust, S.P.; Heere, M.; Nervi, C.; Sørby, M.H.; Hauback, B.C.; Jensen, T.R.R. Synthesis, structure, and polymorphic transitions of praseodymium(iii) and neodymium(iii) borohydride, $\operatorname{Pr}\left(\mathrm{BH}_{4}\right)_{3}$ and $\mathrm{Nd}\left(\mathrm{BH}_{4}\right)_{3}$. Dalton Trans. 2018, 47, 8307-8319. [CrossRef]

110. Gennari, F. Mechanochemical synthesis of erbium borohydride: Polymorphism, thermal decomposition and hydrogen storage. J. Alloys Compd. 2013, 581, 192-195. [CrossRef]

111. Heere, M.; Gharibdoust, S.H.P.; Brighi, M.; Frommen, C.; Sørby, M.H.; Černý, R.; Jensen, T.R.; Hauback, B.C. Hydrogen Sorption in Erbium Borohydride Composite Mixtures with $\mathrm{LiBH}_{4}$ and/or LiH. Inorganics 2017, 5, 31. [CrossRef]

112. West, A.R. Solid State Chemistry and Its Applications; John Wiley \& Sons, Inc.: Hoboken, NJ, USA, 2014.

113. Riktor, M.D.; Deledda, S.; Herrich, M.; Gutfleisch, O.; Fjellvåg, H.; Hauback, B.C. Hydride formation in ball-milled and cryomilled Mg-Fe powder mixtures. Mater. Sci. Eng. B 2009, 158, 19-25. [CrossRef]

114. Floriano, R.; Deledda, S.; Hauback, B.; Leiva, D.; Botta, W.; Botta, W. Iron and niobium based additives in magnesium hydride: Microstructure and hydrogen storage properties. Int. J. Hydrog. Energy 2017, 42, 6810-6819. [CrossRef]

115. Ravnsbæk, D.B.; Frommen, C.; Reed, D.; Filinchuk, Y.; Sørby, M.; Hauback, B.C.; Jakobsen, H.J.; Book, D.; Besenbacher, F.; Skibsted, J.; et al. Structural studies of lithium zinc borohydride by neutron powder diffraction, Raman and NMR spectroscopy. J. Alloys Compd. 2011, 509 (Suppl. 2), S698-S704. [CrossRef]

116. Brower, F.M.; Matzek, N.E.; Reigler, P.F.; Rinn, H.W.; Roberts, C.B.; Schmidt, D.L.; Snover, J.A.; Terada, K. Preparation and properties of aluminum hydride. J. Am. Chem. Soc. 1976, 98, 2450-2453. [CrossRef]

117. Brinks, H.W.; Istad-Lem, A.; Hauback, B.C. Mechanochemical synthesis and crystal structure of alpha'-AlD3 and alpha-AlD3. J. Phys. Chem. B 2006, 110, 25833-25837. [CrossRef] [PubMed]

118. Brinks, H.; Langley, W.; Jensen, C.; Graetz, J.; Reilly, J.; Hauback, B. Synthesis and crystal structure of $\beta$-AlD3. J. Alloys Compd. 2007, 433, 180-183. [CrossRef]

119. Brinks, H.W.; Brown, C.; Jensen, C.M.; Graetz, J.; Reilly, J.J.; Hauback, B.C. The crystal structure of $\gamma$-AlD3. J. Alloys Compd. 2007, 441, 364-367. [CrossRef]

120. Yartys, V.A.; Denys, R.V.; Maehlen, J.P.; Frommen, C.; Fichtner, M.; Bulychev, B.M.; Emerich, H. Double-Bridge Bonding of Aluminium and Hydrogen in the Crystal Structure of $\gamma-\mathrm{AlH}_{3}$. Inorg. Chem. 2007, 46, 1051-1055. [CrossRef] [PubMed]

121. Hauback, B.C. Structures of aluminium-based light weight hydrides. Z. Krist. 2008, 223, 636-648. [CrossRef]

122. Graetz, J.; Hauback, B.C. Recent developments in aluminum-based hydrides for hydrogen storage. MRS Bull. 2013, 38, 473-479. [CrossRef]

123. Grove, H.; Sørby, M.H.; Brinks, H.W.; Hauback, B.C. In situ synchrotron powder X-ray diffraction studies of the thermal decomposition of $\beta$ - and $\gamma$-AlD3. J. Phys. Chem. C 2007, 111, 16693-16699. [CrossRef]

124. Maehlen, J.; Yartys, V.; Denys, R.; Fichtner, M.; Frommen, C.; Bulychev, B.; Pattison, P.; Emerich, H.; Filinchuk, Y.; Chernyshov, D.; et al. Thermal decomposition of $\mathrm{AlH}_{3}$ studied by in situ synchrotron X-ray diffraction and thermal desorption spectroscopy. J. Alloys Compd. 2007, 446, 280-289. [CrossRef]

125. Sartori, S.; Opalka, S.M.; Løvvik, O.M.; Guzik, M.N.; Tang, X.; Hauback, B.C. Experimental studies of $\alpha$-AlD3 and $\alpha^{\prime}$-AlD3 versus first-principles modelling of the alane isomorphs. J. Mater. Chem. 2008, 18, 2361-2370. [CrossRef]

126. Sartori, S.; Istad-Lem, A.; Brinks, H.W.; Hauback, B.C. Mechanochemical synthesis of alane. International J. Hydrog. Energy 2009, 34, 6350-6356. [CrossRef]

127. Fonneløp, J.E.; Sartori, S.; Sørby, M.H.; Hauback, B.C. Polymorphic composition of alane after cryomilling with fluorides. J. Alloys Compd. 2012, 540, 241-247. [CrossRef]

128. Fonneløp, J.E.; Corno, M.; Grove, H.; Pinatel, E.; Sørby, M.H.; Ugliengo, P.; Baricco, M.; Hauback, B.C. Experimental and computational investigations on the $\mathrm{AlH}_{3} / \mathrm{AlF}_{3}$ system. J. Alloys Compd. 2011, 509, $10-14$. [CrossRef] 
129. Brinks, H.W.; Fossdal, A.; Hauback, B.C. Adjustment of the stability of complex hydrides through anion substitution. J. Phys. Chem. C 2008, 112, 5658-5661. [CrossRef]

130. Zhang, J.; Li, Z.; Cuevas, F.; Latroche, M. Phase Stabilities in the Mg-Si-H System Tuned by Mechanochemistry. J. Phys. Chem. C 2014, 118, 21889-21895. [CrossRef]

131. Li, Z.; Zhang, J.; Latroche, M.; Wang, S.M.; Jiang, L.J.; Du, J.; Cuevas, F. Mechanochemical synthesis under deuterium gas in the Li-Mg-N-D system: A neutron diffraction study. Phys. Chem. Chem. Phys 2016, 18, 23944. [CrossRef]

132. Li, Z.; Zhang, J.; Wang, S.; Jiang, L.; Latroche, M.; Du, J.; Cuevas, F. Mechanochemistry of lithium nitride under hydrogen gas. Phys. Chem. Chem. Phys. 2015, 17, 21927-21934. [CrossRef]

133. Chen, P.; Xiong, Z.; Luo, J.; Lin, J.; Tan, K.L. Interaction of hydrogen with metal nitrides and imides. Nature 2002, 420, 302-304. [CrossRef]

134. Luo, W. $\left(\mathrm{LiNH}_{2}-\mathrm{MgH}_{2}\right)$ : A viable hydrogen storage system. J. Alloys Compd. 2004, 381, 284-287. [CrossRef]

135. Matsuo, M.; Orimo, S.-I. Lithium Fast-Ionic Conduction in Complex Hydrides: Review and Prospects. Adv. Energy Mater. 2011, 1, 161-172. [CrossRef]

136. Li, B.; Liu, Y.; Li, C.; Gao, M.; Pan, H. In situ formation of lithium fast-ion conductors and improved hydrogen desorption properties of the $\mathrm{LiNH}_{2}-\mathrm{MgH}_{2}$ system with the addition of lithium halides. J. Mater. Chem. A 2014, 2, 3155. [CrossRef]

137. Li, W.; Wu, G.; Xiong, Z.; Feng, Y.-P.; Chen, P. Li+ ionic conductivities and diffusion mechanisms in Li-based imides and lithium amide. Phys. Chem. Chem. Phys 2012, 14, 1596-1606. [CrossRef] [PubMed]

138. Beister, H.J.; Haag, S.; Kniep, R.; Strössner, K.; Syassen, K. Phase Transformations of Lithium Nitride under Pressure. Angew. Chem. Int. Ed. 1988, 27, 1101-1103. [CrossRef]

139. Bortz, M.; Bertheville, B.; Böttger, G.; Yvon, K. Structure of the high pressure phase g- $\mathrm{MgH}_{2}$ by neutron powder diffraction. J. Alloys Compd. 1999, 287, L4-L6. [CrossRef]

140. Huot, J.; Swainson, I.; Schulz, R. Phase transformation in magnesium hydride induced by ball milling. Eur. J. Control 2006, 31, 135-144. [CrossRef]

141. Cuevas, F.; Korablov, D.; Latroche, M. Synthesis, structural and hydrogenation properties of Mg-rich $\mathrm{MgH}_{2}-\mathrm{TiH}_{2}$ nanocomposites prepared by reactive ball milling under hydrogen gas. Phys. Chem. Chem. Phys. 2012, 14, 1200-1211. [CrossRef]

142. Khawam, A.; Flanagan, D.R. Solid-State Kinetic Models: Basics and Mathematical Fundamentals. J. Phys. Chem. B 2006, 110, 17315-17328. [CrossRef]

143. Weidner, E.; Bull, D.; Shabalin, I.; Keens, S.; Telling, M.; Ross, D.; Ross, K. Observation of novel phases during deuteration of lithium nitride from in situ neutron diffraction. Chem. Phys. Lett. 2007, 444, 76-79. [CrossRef]

144. Behrendt, G.; Reichert, C.; Kohlmann, H. Hydrogenation Reaction Pathways in the Systems $\mathrm{Li}_{3} \mathrm{~N}-\mathrm{H}_{2}$, $\mathrm{Li}_{3} \mathrm{~N}-\mathrm{Mg}-\mathrm{H}_{2}$, and $\mathrm{Li}_{3} \mathrm{~N}-\mathrm{MgH}_{2}-\mathrm{H}_{2}$ by in Situ X-ray Diffraction, in Situ Neutron Diffraction, and in Situ Thermal Analysis. J. Phys. Chem. C 2016, 120, 13450-13455. [CrossRef]

145. Bull, D.J.; Sorbie, N.; Baldissin, G.; Moser, D.; Telling, M.T.F.; Smith, R.I.; Gregory, D.H.; Ross, D.K. In situ powder neutron diffraction study of non-stoichiometric phase formation during the hydrogenation of $\mathrm{Li}_{3} \mathrm{~N}$. Faraday Discuss. 2011, 151, 263-270. [CrossRef] [PubMed]

146. Li, Z.; Qiu, H.C.; Wang, S.M.; Jiang, L.J.; Du, J.; Zhang, J.; Latroche, M.; Cuevas, F. Mechanochemistry and hydrogen storage properties of $2 \mathrm{Li}_{3} \mathrm{~N}+\mathrm{Mg}$ mixture. Rare Met. 2015. [CrossRef]

147. Valiev, R.Z.; Estrin, Y.; Horita, Z.; Langdon, T.G.; Zechetbauer, M.J.; Zhu, Y.T. Producing bulk ultrafine-grained materials by severe plastic deformation. JOM 2006, 58, 33-39. [CrossRef]

148. Zhilyaev, A.P.; Langdon, T.G. Using high-pressure torsion for metal processing: Fundamentals and applications. Prog. Mater. Sci. 2008, 53, 893-979. [CrossRef]

149. Kusadome, Y.; Ikeda, K.; Nakamori, Y.; Orimo, S.-I.; Horita, Z. Hydrogen storage capability of $\mathrm{MgNi}_{2}$ processed by high pressure torsion. Scr. Mater. 2007, 57, 751-753. [CrossRef]

150. Leiva, D.R.; Jorge, A.M.; Ishikawa, T.T.; Huot, J.; Fruchart, D.; Miraglia, S.; Kiminami, C.S.; Botta, W.J. Nanoscale Grain Refinement and H-Sorption Properties of $\mathrm{MgH}_{2}$ Processed by High-Pressure Torsion and Other Mechanical Routes. Adv. Eng. Mater. 2010, 12, 786-792. [CrossRef]

151. Revesz, A.; Kánya, Z.; Verebélyi, T.; Szabó, P.; Zhilyaev, A.; Spassov, T.; Zhilyaev, A. The effect of high-pressure torsion on the microstructure and hydrogen absorption kinetics of ball-milled $\mathrm{Mg}_{70} \mathrm{Ni}_{30}$. J. Alloys Compd. 2010, 504, 83-88. [CrossRef] 
152. Edalati, K.; Yamamoto, A.; Horita, Z.; Ishihara, T. High-pressure torsion of pure magnesium: Evolution of mechanical properties, microstructures and hydrogen storage capacity with equivalent strain. Scr. Mater. 2011, 64, 880-883. [CrossRef]

153. 1De Lima, G.F.; Leiva, D.R.; Ishikawa, T.T.; Bolfarini, C.; Kiminami, C.S.; Botta, W.J.; Jorge, A.M. Hydrogen sorption properties of the complex hydride Mg2FeH6 consolidated by HPT. Mater. Sci. Forum 2011, 2011, 1053-1058.

154. Révész, Á.; Kis-Tóth, Á.; Varga, L.; Schafler, E.; Bakonyi, I.; Spassov, T. Hydrogen storage of melt-spun amorphous $\mathrm{Mg}_{65} \mathrm{Ni}_{20} \mathrm{Cu}_{5} \mathrm{Y}_{10}$ alloy deformed by high-pressure torsion. Int. J. Hydrog. Energy 2012, 37, 5769-5776. [CrossRef]

155. Botta, W.J.; Jorge Jr, A.M.; Veron, M.; Rauch, E.F.; Ferrie, E.; Yavari, A.R.; Huot, J.; Leiva, D.R. H-sorption properties and structural evolution of $\mathrm{Mg}$ processed by severe plastic deformation. J. Alloys Compd. 2013, 580, S187-S191. [CrossRef]

156. Zou, J.X.; Pérez-Brokate, C.F.; Arruffat, R.; Bolle, B.; Fundenberger, J.J.; Zeng, X.Q.; Grosdidier, T.; Ding, W.J. Nanostructured bulk Mg $+\mathrm{MgO}$ composite synthesized through arc plasma evaporation and high pressure torsion for H-storage application. Mater. Sci. Eng. B 2014, 183, 1-5. [CrossRef]

157. Hongo, T.; Edalati, K.; Arita, M.; Matsuda, J.; Akiba, E.; Horita, Z. Significance of grain boundaries and stacking faults on hydrogen storage properties of $\mathrm{Mg}_{2} \mathrm{Ni}$ intermetallics processed by high-pressure torsion. Acta Mater. 2015, 92, 46-54. [CrossRef]

158. Grosdidier, T.; Fundenberger, J.; Zou, J.; Pan, Y.; Zeng, X. Nanostructured Mg based hydrogen storage bulk materials prepared by high pressure torsion consolidation of arc plasma evaporated ultrafine powders. Int. J. Hydrog. Energy 2015, 40, 16985-16991. [CrossRef]

159. Xu, C.; Lin, H.; Edalati, K.; Li, W.; Li, L.; Zhu, Y. Superior hydrogenation properties in a Mg65Ce20Ni10Cu5 nanoglass processed by melt-spinning followed by high-pressure torsion. Scr. Mater. 2018, 152, 137-140. [CrossRef]

160. Panda, S.; Fundenberger, J.-J.; Zhao, Y.; Zou, J.; Toth, L.S.; Grosdidier, T. Effect of initial powder type on the hydrogen storage properties of high-pressure torsion consolidated Mg. Int. J. Hydrog. Energy 2017, 42, 22438-22448. [CrossRef]

161. Grill, A.; Horky, J.; Panigrahi, A.; Krexner, G.; Zehetbauer, M. Long-term hydrogen storage in Mg and ZK60 after Severe Plastic Deformation. Int. J. Hydrog. Energy 2015, 40, 17144-17152. [CrossRef]

162. Edalati, K.; Matsuda, J.; Iwaoka, H.; Toh, S.; Akiba, E.; Horita, Z. High-pressure torsion of TiFe intermetallics for activation of hydrogen storage at room temperature with heterogeneous nanostructure. Int. J. Hydrog. Energy 2013, 38, 4622-4627. [CrossRef]

163. Edalati, K.; Matsuda, J.; Arita, M.; Daio, T.; Akiba, E.; Horita, Z. Mechanism of activation of TiFe intermetallics for hydrogen storage by severe plastic deformation using high-pressure torsion. Appl. Phys. Lett. 2013, 103, 143902. [CrossRef]

164. Edalati, K.; Matsuda, J.; Yanagida, A.; Akiba, E.; Horita, Z. Activation of TiFe for hydrogen storage by plastic deformation using groove rolling and high-pressure torsion: Similarities and differences. Int. J. Hydrog. Energy 2014, 39, 15589-15594. [CrossRef]

165. Edalati, K.; Matsuo, M.; Emami, H.; Itano, S.; Alhamidi, A.; Staykov, A.; Smith, D.J.; Orimo, S.-I.; Akiba, E.; Horita, Z. Impact of severe plastic deformation on microstructure and hydrogen storage of titanium-iron-manganese intermetallics. Scr. Mater. 2016, 124, 108-111. [CrossRef]

166. Edalati, K.; Shao, H.; Emami, H.; Iwaoka, H.; Akiba, E.; Horita, Z. Activation of titanium-vanadium alloy for hydrogen storage by introduction of nanograins and edge dislocations using high-pressure torsion. Int. J. Hydrog. Energy 2016, 41, 8917-8924. [CrossRef]

167. Edalati, K.; Novelli, M.; Itano, S.; Li, H.-W.; Akiba, E.; Horita, Z.; Grosdidier, T. Effect of gradient-structure versus uniform nanostructure on hydrogen storage of Ti-V-Cr alloys: Investigation using ultrasonic SMAT and HPT processes. J. Alloys Compd. 2018, 737, 337-346. [CrossRef]

168. Edalati, K.; Uehiro, R.; Ikeda, Y.; Li, H.-W.; Emami, H.; Filinchuk, Y.; Arita, M.; Sauvage, X.; Tanaka, I.; Akiba, E.; et al. Design and synthesis of a magnesium alloy for room temperature hydrogen storage. Acta Mater. 2018, 149, 88-96. [CrossRef]

169. Fujiwara, K.; Uehiro, R.; Edalati, K.; Li, H.-W.; Floriano, R.; Akiba, E.; Horita, Z. New Mg-V-Cr BCC Alloys Synthesized by High-Pressure Torsion and Ball Milling. Mater. Trans. 2018, 59, 741-746. [CrossRef] 
170. Edalati, K.; Uehiro, R.; Fujiwara, K.; Ikeda, Y.; Li, H.-W.; Sauvage, X.; Valiev, R.Z.; Akiba, E.; Tanaka, I.; Horita, Z. Ultra-severe plastic deformation: Evolution of microstructure, phase transformation and hardness in immiscible magnesium-based systems. Mater. Sci. Eng. A 2017, 701, 158-166. [CrossRef]

171. Edalati, K.; Akiba, E.; Horita, Z. High-pressure torsion for new hydrogen storage materials. Sci. Technol. Adv. Mater. 2018, 19, 185-193. [CrossRef]

172. Edalati, K.; Daio, T.; Lee, S.; Horita, Z.; Nishizaki, T.; Akune, T.; Nojima, T.; Sasaki, T. High strength and superconductivity in nanostructured niobium-titanium alloy by high-pressure torsion and annealing: Significance of elemental decomposition and supersaturation. Acta Mater. 2014, 80, 149-158. [CrossRef]

173. Edalati, K.; Emami, H.; Staykov, A.; Smith, D.J.; Akiba, E.; Horita, Z. Formation of metastable phases in magnesium-titanium system by high-pressure torsion and their hydrogen storage performance. Acta Mater. 2015, 99, 150-156. [CrossRef]

174. Emami, H.; Edalati, K.; Staykov, A.; Hongo, T.; Iwaoka, H.; Horita, Z.; Akiba, E. Solid-state reactions and hydrogen storage in magnesium mixed with various elements by high-pressure torsion: Experiments and first-principles calculations. RSC Adv. 2016, 6, 11665-11674. [CrossRef]

175. Edalati, K.; Emami, H.; Ikeda, Y.; Iwaoka, H.; Tanaka, I.; Akiba, E.; Horita, Z. New nanostructured phases with reversible hydrogen storage capability in immiscible magnesium-zirconium system produced by high-pressure torsion. Acta Mater. 2016, 108, 293-303. [CrossRef]

176. Reilly, J.J.; Wiswall, R.H. Formation and properties of iron titanium hydride. Inorg. Chem. 1974, 13, $218-222$. [CrossRef]

177. Emami, H.; Edalati, K.; Matsuda, J.; Akiba, E.; Horita, Z. Hydrogen storage performance of TiFe after processing by ball milling. Acta Mater. 2015, 88, 190-195. [CrossRef]

178. Nomura, K.; Uruno, H.; Ono, S.; Shinozuka, H.; Suda, S. Effects of lattice strain on the hysteresis of pressure-composition isotherms for the $\mathrm{LaNi}_{5} \mathrm{H}_{2}$ system. J. Less Common Met. 1985, 107, 221-230. [CrossRef]

179. Inui, H.; Yamamoto, T.; Hirota, M.; Yamaguchi, M. Lattice defects introduced during hydrogen absorption-desorption cycles and their effects on $\mathrm{P}-\mathrm{C}$ characteristics in some intermetallic compounds. J. Alloys Compd. 2002, 330, 117-124. [CrossRef]

180. Nagel, H.; Perkins, R.S. Crystallographic Investigation of Ternary Titanium Vanadium Hydrides. Z. Met. 1975, 66, 362-366.

181. Ono, S.; Nomura, K.; Ikeda, Y. The raction of hydrogen with alloys of vanadium and titanium. J. Less Common Met. 1980, 72, 159-165. [CrossRef]

182. Hara, S.; Sakaki, K.; Itoh, N.; Kimura, H.-M.; Asami, K.; Inoue, A. An amorphous alloy membrane without noble metals for gaseous hydrogen separation. J. Membr. Sci. 2000, 164, 289-294. [CrossRef]

183. Nagai, H.; Kitagaki, K.; Shoji, K. Microstructure and hydriding characteristics of FeTi alloys containing manganese. J. Less Common Met. 1987, 134, 275-286. [CrossRef]

184. Lee, S.M.; Perng, T.P. Effect of the 2nd phase on the initiation of hydrogenation of TiFe1-xMx $(\mathrm{M}=\mathrm{Cr}, \mathrm{Mn})$ alloys. Int. J. Hydrog. Energy 1994, 19, 259-263. [CrossRef]

185. Rigney, D.; Naylor, M.; Divakar, R.; Ives, L. Low energy dislocation structures caused by sliding and by particle impact. Mater. Sci. Eng. 1986, 81, 409-425. [CrossRef]

186. Samih, Y.; Marcos, G.; Stein, N.; Allain, N.; Fleury, E.; Dong, C.; Grosdidier, T. Microstructure modifications and associated hardness and corrosion improvements in the AISI 420 martensitic stainless steel treated by high current pulsed electron beam (HCPEB). Surf. Coat. Technol. 2014, 259, 737-745. [CrossRef]

187. Lu, K.; Lu, J. Nanostructured surface layer on metallic materials induced by surface mechanical attrition treatment. Mater. Sci. Eng. A 2004, 375, 38-45. [CrossRef]

188. Liu, G.; Lü, J.; Lu, K. Surface nanocrystallization of 316L stainless steel induced by ultrasonic shot peening. Mater. Sci. Eng. A 2000, 286, 91-95. [CrossRef]

189. Bagherifard, S.; Guagliano, M. Fatigue behavior of a low-alloy steel with nanostructured surface obtained by severe shot peening. Eng. Fract. Mech. 2012, 81, 56-68. [CrossRef]

190. Novelli, M.; Fundenberger, J.-J.; Bocher, P.; Grosdidier, T. On the effectiveness of surface severe plastic deformation by shot peening at cryogenic temperature. Appl. Surf. Sci. 2016, 389, 1169-1174. [CrossRef]

191. Novelli, M.; Bocher, P.; Grosdidier, T. Effect of cryogenic temperatures and processing parameters on gradient-structure of a stainless steel treated by ultrasonic surface mechanical attrition treatment. Mater. Charact. 2018, 139, 197-207. [CrossRef] 
192. Badreddine, J.; Rouhaud, E.; Micoulaut, M.; Remy, S. Simulation of shot dynamics for ultrasonic shot peening: Effects of process parameters. Int. J. Mech. Sci. 2014, 82, 179-190. [CrossRef]

193. Akiba, E.; Iba, H. Hydrogen absorption by Laves phase related BCC solid solution. Intermetallics 1998, 6, 461-470. [CrossRef]

194. Yu, X.; Wu, Z.; Xia, B.; Xu, N. The activation mechanism of Ti-V-based hydrogen storage alloys. J. Alloys Compd. 2004, 375, 221-223. [CrossRef]

195. Miraglia, S.; De Rango, P.; Rivoirard, S.; Fruchart, D.; Charbonnier, J.; Skryabina, N. Hydrogen sorption properties of compounds based on BCC $\mathrm{Ti}_{1}-\mathrm{xV}_{1}-\mathrm{yCr} \mathrm{r}_{1}+\mathrm{x}+\mathrm{y}$ alloys. J. Alloys Compd. 2012, 536, 1-6. [CrossRef]

196. Huot, J.; Enoki, H.; Akiba, E. Synthesis, phase transformation, and hydrogen storage properties of ball-milled $\mathrm{TiV}_{0.9} \mathrm{Mn}_{1.1}$. J. Alloys Compd. 2008, 453, 203-209. [CrossRef]

197. Matsuda, J.; Akiba, E. Lattice defects in V-Ti BCC alloys before and after hydrogenation. J. Alloys Compd. 2013, 581, 369-372. [CrossRef]

198. Kim, H.; Sakaki, K.; Ogawa, H.; Nakamura, Y.; Nakamura, J.; Akiba, E.; Machida, A.; Watanuki, T.; Proffen, T. Origin of Degradation in the Reversible Hydrogen Storage Capacity of V1-xTixAlloys from the Atomic Pair Distribution Function Analysis. J. Phys. Chem. C 2013, 117, 26543-26550. [CrossRef]

199. Huot, J. Enhancing Hydrogen Storage Properties of Metal Hydrides; Springer: Berlin, Germany, 2016; p. 39.

200. Ueda, T.T.; Tsukahara, M.; Kamiya, Y.; Kikuchi, S. Preparation and hydrogen storage properties of $\mathrm{Mg}-\mathrm{Ni}-\mathrm{Mg}_{2} \mathrm{Ni}$ laminate composites. J. Alloys Compd. 2005, 386, 253-257. [CrossRef]

201. Dufour, J.; Huot, J. Rapid activation, enhanced hydrogen sorption kinetics and air resistance in laminated Mg-Pd 2.5at.\%. J. Alloys Compd. 2007, 439, L5-L7. [CrossRef]

202. Dufour, J.; Huot, J. Study of $\mathrm{Mg}_{6}$ Pd alloy synthesized by cold rolling. J. Alloys Compd. 2007, 446, $147-151$. [CrossRef]

203. Løken, S.; Solberg, J.; Maehlen, J.; Denys, R.; Lototsky, M.; Tarasov, B.; Yartys, V.; Denys, R. Nanostructured $\mathrm{Mg}-\mathrm{Mm}-\mathrm{Ni}$ hydrogen storage alloy: Structure-properties relationship. J. Alloys Compd. 2007, 446, 114-120. [CrossRef]

204. Mori, R.; Miyamura, H.; Kikuchi, S.; Tanaka, K.; Takeichi, N.; Tanaka, H.; Kuriyama, N.; Ueda, T.T.; Tsukahara, M. Hydrogenation Characteristics of Mg Based Alloy Prepared by Super Lamination Technique. Mater. Sci. Forum 2007, 561, 1609-1612. [CrossRef]

205. Suganuma, K.; Miyamura, H.; Kikuchi, S.; Takeichi, N.; Tanaka, K.; Tanaka, H.; Kuriyama, N.; Ueda, T.T.; Tsukahara, M. Hydrogen Storage Properties of Mg-Al Alloy Prepared by Super Lamination Technique. Adv. Mater. Res. 2007, 26, 857-860. [CrossRef]

206. Takeichi, N.; Tanaka, K.; Tanaka, H.; Ueda, T.T.; Kamiya, Y.; Tsukahara, M.; Miyamura, H.; Kikuchi, S. The hydrogen storage properties of $\mathrm{Mg} / \mathrm{Cu}$ and $\mathrm{Mg} / \mathrm{Pd}$ laminate composites and metallographic structure. J. Alloys Compd. 2007, 446-447, 543-548. [CrossRef]

207. Takeichi, N.; Tanaka, K.; Tanaka, H.; Ueda, T.T.; Tsukahara, M.; Miyamura, H.; Kikuchi, S. Hydrogen Storage Properties and Corresponding Phase Transformations of Mg/Pd Laminate Composites Prepared by a Repetitive-Rolling Method. Mater. Trans. 2007, 48, 2395-2398. [CrossRef]

208. Ebrahimi-Purkani, A.; Kashani-Bozorg, S. Nanocrystalline Mg2Ni-based powders produced by high-energy ball milling and subsequent annealing. J. Alloys Compd. 2008, 456, 211-215. [CrossRef]

209. Pedneault, S.; Huot, J.; Roué, L. Nanostructured Mg2Ni materials prepared by cold rolling and used as negative electrode for Ni-MH batteries. J. Power Sources 2008, 185, 566-569. [CrossRef]

210. Pedneault, S.; Roué, L.; Huot, J. Synthesis of Metal Hydrides by Cold Rolling. Mater. Sci. Forum 2008, 570, 33-38. [CrossRef]

211. Danaie, M.; Mauer, C.; Mitlin, D.; Huot, J. Hydrogen storage in bulk Mg-Ti and Mg-stainless steel multilayer composites synthesized via accumulative roll-bonding (ARB). Int. J. Hydrog. Energy 2011, 36, 3022-3036. [CrossRef]

212. Lang, J.; Huot, J. A new approach to the processing of metal hydrides. J. Alloys Compd. 2011, 509, L18-L22. [CrossRef]

213. Leiva, D.; Floriano, R.; Huot, J.; Jorge, A.; Bolfarini, C.; Kiminami, C.; Ishikawa, T.; Botta, W.; Leiva, D.; Kiminami, C.; et al. Nanostructured $\mathrm{MgH}_{2}$ prepared by cold rolling and cold forging. J. Alloys Compd. 2011, 509, S444-S448. [CrossRef] 
214. Amira, S.; Huot, J. Effect of cold rolling on hydrogen sorption properties of die-cast and as-cast magnesium alloys. J. Alloys Compd. 2012, 520, 287-294. [CrossRef]

215. Bellemare, J.; Huot, J. Hydrogen storage properties of cold rolled magnesium hydrides with oxides catalysts. J. Alloys Compd. 2012, 512, 33-38. [CrossRef]

216. Floriano, R.; Leiva, D.R.; Deledda, S.; Hauback, B.C.; Botta, W.J. Nanostructured $\mathrm{MgH}_{2} \mathrm{Obtained}_{\text {by Cold }}$ Rolling Combined with Short-time High-energy Ball Milling. Mater. Res. Ibero am. J. Mater. 2013, 16, 158-163. [CrossRef]

217. Floriano, R.; Leiva, D.; Deledda, S.; Hauback, B.; Botta, W.; Leiva, D.; Botta, W. Cold rolling of MgH $\mathrm{H}_{2}$ powders containing different additives. Int. J. Hydrog. Energy 2013, 38, 16193-16198. [CrossRef]

218. Zhang, H.; Huang, G.; Wang, L.; Roven, H.J.; Pan, F. Enhanced mechanical properties of AZ31 magnesium alloy sheets processed by three-directional rolling. J. Alloys Compd. 2013, 575, 408-413. [CrossRef]

219. Floriano, R.; Leiva, D.; Deledda, S.; Hauback, B.; Botta, W.; Botta, W. $\mathrm{MgH}_{2}$-based nanocomposites prepared by short-time high energy ball milling followed by cold rolling: A new processing route. Int. J. Hydrog. Energy 2014, 39, 4404-4413. [CrossRef]

220. Asselli, A.; Leiva, D.; Huot, J.; Kawasaki, M.; Langdon, T.; Botta, W. Effects of equal-channel angular pressing and accumulative roll-bonding on hydrogen storage properties of a commercial ZK60 magnesium alloy. Int. J. Hydrog. Energy 2015, 40, 16971-16976. [CrossRef]

221. Faisal, M.; Gupta, A.; Shervani, S.; Balani, K.; Subramaniam, A. Enhanced hydrogen storage in accumulative roll bonded Mg-based hybrid. Int. J. Hydrog. Energy 2015, 40, 11498-11505. [CrossRef]

222. Li, Q.; Lin, Q.; Chou, K.-C.; Jiang, L.-J.; Zhan, F. Hydrogen storage properties of mechanically alloyed Mg-8 mol\% LaNi0.5 composite. J. Mater. Res. 2004, 19, 2871-2876. [CrossRef]

223. Liu, D.; Liu, X.; Zhu, Y.; Li, L. Hydriding combustion synthesis of $\mathrm{Mg}-\mathrm{CaNi}_{5}$ composites. J. Alloys Compd. 2008, 458, 394-397. [CrossRef]

224. Soyama, J.; Floriano, R.; Leiva, D.R.; Guo, Y.; Jorge Junior, A.M.; Pereira da Silva, E.; Pinto, H.C.; Bolfarini, C.; Kiminami, C.S.; Botta, W.J. Severely deformed ZK60 + 2.5\% Mm alloy for hydrogen storage produced by two different processing routes. Int. J. Hydrog. Energy 2016, 41, 11284-11292. [CrossRef]

225. Floriano, R.; Leiva, D.; Melo, G.; Ishikawa, T.; Huot, J.; Kaufman, M.; Figueroa, S.; Mendoza-Zélis, L.; Damonte, L.; Botta, W. Low temperature rolling of AZ91 alloy for hydrogen storage. Int. J. Hydrog. Energy 2017, 42, 29394-29405. [CrossRef]

226. Jung, J.Y.; Fadonougbo, J.O.; Suh, J.-Y.; Lee, Y.-S.; Huh, J.-Y.; Cho, Y.W. Synthesis of Mg2FeH6 by hydrogenation of $\mathrm{Mg} / \mathrm{Fe}$ powder mixture prepared by cold roll milling in air: Effects of microstructure and oxygen distribution. Int. J. Hydrog. Energy 2018, 43, 16758-16765. [CrossRef]

227. Márquez, J.J.; Leiva, D.R.; Floriano, R.; Soyama, J.; Silva, W.B.; Ishikawa, T.T.; Kiminami, C.S.; Botta, W.J. Hydrogen storage in $\mathrm{MgH} 2 \mathrm{LaNi} 5$ composites prepared by cold rolling under inert atmosphere. Int. J. Hydrog. Energy 2018, 43, 13348-13355. [CrossRef]

228. Yoo, M.H. Slip, twinning, and fracture in hexagonal close-packed metals. Met. Mater. Trans. A 1981, 12, 409-418. [CrossRef]

229. Tonda, H.; Ando, S. Effect of temperature and shear direction on yield stress by $\{1122\}<1123>$ slip in HCP metals. Met. Mat Trans A 2002, 33, 831-836. [CrossRef]

230. Broom, D.P. Hydrogen Storage Materials: The Characterisation of Their Storage Properties; Springer: Berlin, Germany, 2011; p. 258.

231. Vucht, J.H.N.V.; Kuijpers, F.A.; Bruning, H.C.A.M. Reversible room-temperature absorption of large quantities of hydrogen by intermetallic compounds. Philips Res. Rep. 1970, 25, 133.

232. Hanada, N.; Nakagawa, T.; Asada, H.; Ishida, M.; Takahashi, K.; Isobe, S.; Saita, I.; Asano, K.; Nakamura, Y.; Fujisawa, A.; et al. Dependence of constituent elements of AB 5 type metal hydrides on hydrogenation degradation by $\mathrm{CO}_{2}$ poisoning. J. Alloys Compd. 2015, 647, 198-203. [CrossRef]

233. Seta, S.; Uchida, H. Hydrogen solubility in LaNi 5 . J. Alloys Compd. 1995, 231, 448-453. [CrossRef]

234. Termsuksawad, P.; Niyomsoan, S.; Mishra, B.; Olson, D.; Gavra, Z.; Kaydanov, V. Prediction of hydrogen absorption behavior in AB5 hydrogen storage alloys by electronic techniques. Mater. Sci. Eng. B 2005, 117, 45-51. [CrossRef]

235. Uchida, H.; Sato, M.; Moriwaki, O. Hydrogen absorption and desorption isotherms in the solid solution regions of the $\mathrm{LaNi}_{5}-\mathrm{H}$ system. J. Alloys Compd. 1997, 253-254, 235-237. [CrossRef] 
236. Tousignant, M.; Huot, J. Hydrogen sorption enhancement in cold rolled LaNi 5 . J. Alloys Compd. 2014, 595, 22-27. [CrossRef]

237. Huot, J.; Tousignant, M. Hydrogen sorption enhancement in cold-rolled and ball-milled CaNi 5 . J. Mater. Sci. 2017, 52, 11911-11918. [CrossRef]

238. Yoshikawa, A.; Uyenishi, Y.; Iizumi, H.; Matsumoto, T.; Takano, N.; Terasaki, F. Determination of the positionand occupancy of deuterium in $\mathrm{CaNi}_{5}$ deuterides by neutron diffraction. J. Alloys Compd. 1998, 280, 204-208. [CrossRef]

239. Couillaud, S.; Enoki, H.; Amira, S.; Bobet, J.; Akiba, E.; Huot, J. Effect of ball milling and cold rolling on hydrogen storage properties of nanocrystalline TiV1.6Mn0.4 alloy. J. Alloys Compd. 2009, 484, 154-158. [CrossRef]

240. Dupim, I.; Moreira, J.; Huot, J.; Santos, S. Effect of cold rolling on the hydrogen absorption and desorption kinetics of Zircaloy-4. Mater. Chem. Phys. 2015, 155, 241-245. [CrossRef]

241. Khajavi, S.; Rajabi, M.; Huot, J. Effect of cold rolling and ball milling on first hydrogenation of $\operatorname{Ti}_{0.5} \mathrm{Zr}_{0.5}$ $\left(\mathrm{Mn}_{1-\mathrm{x}} \mathrm{Fe}_{\mathrm{x}}\right) \mathrm{Cr}_{1}, \mathrm{x}=0,0.2,0.4$. J. Alloys Compd. 2019, 775, 912-920. [CrossRef]

242. Leiva, D.R.; Costa, H.C.D.A.; Huot, J.; Pinheiro, T.S.; Junior, A.M.J.; Ishikawa, T.T.; Filho, W.J.B. Magnesium-Nickel alloy for hydrogen storage produced by melt spinning followed by cold rolling. Mater. Res. 2012, 15, 813-817. [CrossRef]

243. Lima, G.F.; Triques, M.R.M.; Kiminami, C.S.; Botta, W.J.; Jorge Jr, A.M. Hydrogen storage properties of 2Mg-Fe after the combined processes of hot extrusion and cold rolling. J. Alloys Compd. 2014, 586 (Suppl. 1), S409-S412. [CrossRef]

244. Friščić, T.; Halasz, I.; Beldon, P.J.; Belenguer, A.M.; Adams, F.; Kimber, S.A.J.; Honkimäki, V.; Dinnebier, R.E. Real-time and in situ monitoring of mechanochemical milling reactions. Nat. Chem. 2013, 5, 66-73. [CrossRef]

245. Halasz, I.; Kimber, S.A.J.; Beldon, P.J.; Belenguer, A.M.; Adams, F.; Honkimäki, V.; Nightingale, R.C.; E Dinnebier, R.; Friščić, T. In situ and real-time monitoring of mechanochemical milling reactions using synchrotron X-ray diffraction. Nat. Protoc. 2013, 8, 1718-1729. [CrossRef]

246. Katsenis, A.D.; Puškarić, A.; Strukil, V.; Mottillo, C.; Julien, P.A.; Uzarevic, K.; Pham, M.-H.; Do, T.-O.; Kimber, S.A.J.; Lazić, P.; et al. In situ X-ray diffraction monitoring of a mechanochemical reaction reveals a unique topology metal-organic framework. Nat. Commun. 2015, 6, 6662. [CrossRef] [PubMed]

247. Filinchuk, Y.; Ban, V.; Morelle, F.; Tumanov, N.; Dovgaliuk, I.; Cerny, R.; Sadikin, Y.; Schouwink, P. Mechanochemical synthesis of hydrides followed in situ by X-ray diffraction. In Proceedings of the 14th International Symposium on Metal-Hydrogen Systems: Fundamentals and Applications (MH2014), Manchwiester, UK, 17 February 2014.

248. Batzdorf, L.; Fischer, F.; Wilke, M.; Wenzel, K.-J.; Emmerling, F. Direct in situ investigation of milling reactions using combined x-ray diffraction and raman spectroscopy. Angew. Chem. Int. Ed. 2015, 54, 1799-1802. [CrossRef] [PubMed]

249. Halasz, I.; Užarević, K.; Friščić, T. Real-Time and in Situ Monitoring of Mechanochemical Reactions: A New Playground for All Chemists. J. Phys. Chem. Lett. 2015, 6, 4129-4140.

250. Halasz, I.; Puškarić, A.; Kimber, S.A.J.; Beldon, P.J.; Belenguer, A.M.; Adams, F.; Honkimäki, V.; Dinnebier, R.E.; Patel, B.; Jones, W.; et al. Real-Time in Situ Powder X-ray Diffraction Monitoring of Mechanochemical Synthesis of Pharmaceutical Cocrystals. Angew. Chem. 2013, 125, 11752-11755. [CrossRef]

251. Fischer, F.; Heidrich, A.; Greiser, S.; Benemann, S.; Rademann, K.; Emmerling, F. Polymorphism of Mechanochemically Synthesized Cocrystals: A Case Study. Cryst. Growth Des. 2016, 16, 1701-1707. [CrossRef]

252. Fischer, F.; Lubjuhn, D.; Greiser, S.; Rademann, K.; Emmerling, F. Supply and Demand in the Ball Mill: Competitive Cocrystal Reactions. Cryst. Growth Des. 2016, 16, 5843-5851. [CrossRef]

253. Gracin, D.; Štrukil, V.; Friščić, T.; Halasz, I.; Užarević, K. Laboratory Real-Time and in Situ Monitoring of Mechanochemical Milling Reactions by Raman Spectroscopy. Angew. Chem. 2014, 126, 6307-6311. [CrossRef]

254. Kulla, H.; Haferkamp, S.; Akhmetova, I.; Röllig, M.; Maierhofer, C.; Rademann, K.; Emmerling, F.L. In Situ Investigations of Mechanochemical One-Pot Syntheses. Angew. Chem. Int. Ed. 2018, 57, 5930-5933. [CrossRef] 
255. Tumanov, N.; Ban, V.; Poulain, A.; Filinchuk, Y. 3D-printed jars for ball-milling experiments monitored in situ by X-ray powder diffraction. J. Appl. Crystallogr. 2017, 50, 994-999. [CrossRef]

256. Ban, V.; Sadikin, Y.; Lange, M.; Tumanov, N.; Filinchuk, Y.; Černý, R.; Casati, N. Innovative in Situ Ball Mill for X-ray Diffraction. Anal. Chem. 2017, 89, 13176-13181. [CrossRef]

(C) 2019 by the authors. Licensee MDPI, Basel, Switzerland. This article is an open access article distributed under the terms and conditions of the Creative Commons Attribution (CC BY) license (http://creativecommons.org/licenses/by/4.0/). 